

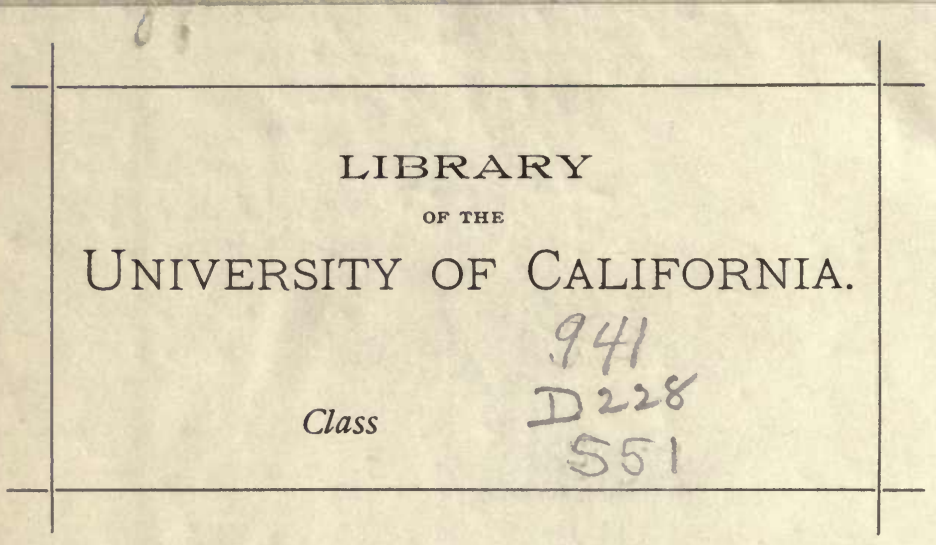






\title{
MEMOIRS OF THE LIFE
}

\author{
of \\ Erasmus \\ DR. DARWIN,
}

CHIEFLY DURING HIS RESIDENCE AT LICHFIELD,

WITH

ANECDOTES OF HIS FRIENDS,

AND

CRITICISMS ON HIS WRITINGS:

By ANNA SEWARD.

\section{LONDON :}

PRINTED FOR J. JOHNSON, ST. FAUL'S CHURCH-YARD, BY T. BENSLEY, BOLT COVRT.

1804. 


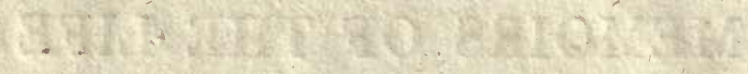

$$
83
$$

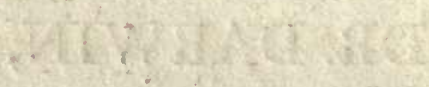 BENERAL}
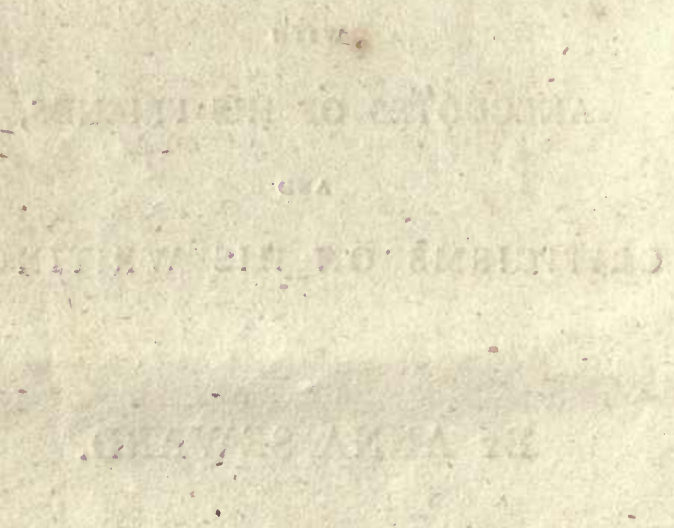


\section{RIGHT HONORABLE}

\section{THE EARL OF CARLISLE.}

IMY LORD,

WHERE hereditary honors, $\int$ plendid fortune, and perfonal graces, have fecured, from the firft dawn of youth, the external repect and gratifying attention of the world, it is feldom found that their poleflor has emulouly and feduloufly diftilled the fweetnes from the clafic fountains. There is no flattery in obferving, that of thofe rare infances your LordSip is confpicuoully one. Such energetic induftry involves a fuperior claim to eftimation than where it has appeared the only means by which native talent and laudable ambition could have pierced the mifts of obfcurity.

You, Sir, have nobly chofen to adorn your rank, inftead of indolently leaning upon it's inherent diftinction, or even fatisfying yourfelf 
with the acquirement of Senatorial eloquence. Profeffedly a difciple of the Mufes, and on public proof an highly-favored difciple, you muft be interefted in the life and character of one of the moft eminent of your poetic contemporaries.

Hence, my Lord, do I prefume to lay theje Memoirs of Dr. Darwin at your feet. From all I hear of Lord Carlifle's virtues, as from all I know of his genius, it is one of my fir $\mathrm{t}$ wighes for this little Trast, that it may intereft and amuje a tranfient hour of his leifure, and obtain that approbation from him which muft reward biographic integrity, ws hile literary reputation brightens in his fmile.

I have the honor to be, with the moft perfect reßpect and efteem,

$$
\text { My Lord, }
$$

Your Lordjhip's faithful

and obedient fervant, 


\section{PREFACE.}

IN publifhing thefe Memoirs of the Life and Writings of Dr. Darwin, I am confcious of their defects; that they do not form a regular detail of biographical circumftances, even in that moiety of his profeffional exiftence formed by his refidence at Lichfield; while of that which paffed at Derby I am qualified to prefent no more than a merely general view.

My work confifts of the following particulars: the perfon, the mind, the temper of Dr. Darwin; his powers as a Phyfician, Philofopher, and Poet; the peculiar traits of his manners; his excellencies and faults; the Petrarchan attachment of his middle life, more happy in it's refult than was that of the Bard of Vauclufe; the beautiful poetic teftimonies of it's fervor, while yet 
it remained hopelefs; an inveftigation of the conftituent excellencies and defects of his magnificent poem; the Botanic Garden; remarks upon his philofophic profe writings; the characters and talents of thofe who formed the circle of his friends while he refided in Lichfield; and the very fingular and interefting hiftory of one of them, well-known in the lettered world, whofe domeftic hiftory, remarkable as it is, has been unaccountably omitted by the gentleman who wrote his life.

Dr. Darwin's Letters make no part of thefe Memoirs. Poffeffing few of them myfelf, and thofe perfectly inconfequential, no effort has here been made to obtain them from others. He lived not, like Pope and Swift, Gray and Johnfon, in exclufive devotion to abitract literature. During fuch hours of repofe, compared to his buify and hurried life, he might have found leifure to pour his imagination and his knowledge 
ledge on the epiftolary page; but his epiftles, though profeffionally numerous, were short from neceffity, and by choice compreffed. He has often faid that he had not the talent of elegant letter-writing. Like all other diftinguifhed acquirements, it can only obtain excellence from frequent and diffure practice, unreftrained by the interfering preffure of extrinfic confiderations.

It was alfo his frequent remark, that literary fame invariably fuffers by the publication of every thing which is below the level of that celebrity which it has already gained. Letters, through whofe progrefs either wit fcatters it's fcintillations, criticifm it's inftruction, knowledge it's treafures, or fancy it's glow, are not beneath the dignity of the moft eminent reputation; but fince coercive circumftances in a great meafure precluded thofe effufions to the letters of Darwin, there would be no 
kindnefs to his memory in obtruding them upon the public; none to the public in fwelling out books with materials of no intrinfic value. It is only zeal without judgment, and the enthufiafm of partiality, which can take pleafure in reading a great man's letters, which might have been thofe of any tolerably educated mind, on which genius had never thone.

Biography of recently departed Eminence is apt to want characteriftic truth, fince it is generally written either by a near relation,

Who writes to thare the fame of the deceafed,

So high in merit, and to him fo dear !

Such dwell on praifes which they think they fhare*;

or by an highly obliged friend, whom gratitude and affection render blindly partial, and who is influenced by a defire of gratifying, with a defcription of all-exceling endowment and angelic excellence, 
the furviving family of the author he commemorates; or by an editor who believes it highly conducive to his profits on the writings he publines, or republifhes, to claim for their author the unqualified admiration and reverence of mankind. All thefe claffes of biographers do for the perfon whom they commemorate, what our generally wife Queen Elizabeth had the weaknefs to requeft her painters would do for her portrait on the canvafs; they draw a picture without thades.

But though people of credulous and effervefcent zeal may be gratified by feeing a writer, whofe works have charmed them, thus invefted with unrivalled genius and fuper-human virtue, the judicious few, whofe approbation is genuine honor, are aware of this truth, afferted by Mrs. Barbauld in her beautiful, her ineftimable Efray againft Inconfiftency in our Expectations. "Nature is much too frugal to "heap 
" heap together all manner of Mining "qualities in one glaring mafs *." Every man has his errors, and the errors of public characters are too well known not to expofe unfounded eulogium to the diftafte of all who prefer truth to enthufiafm. They are confcious that the mind, as well as the perfon, of a celebrated character, ought to be drawn with difpaffionate fidelity, or not attempted; that though juft biographic record will touch the failings of the good and the eminent with tendernefs, it ought not to fpread over them the veil of fuppreffion. A portrait painter might as well omit each appropriate diftinction of feature, countenance, and form, becaufe it may not be elegant, and, like the Limner in Gay's Fables, finifh his pictures from cafts of the Venus and Apollo, as the hiftorian conceal the faults, foibles, and weakneffes of the individual whom he delineates.

* Aikin's and Barbauld's Effays. 
It is this fidelity of reprefentation which makes Mrs. Piozzi's Memoirs of Dr. Johnfon, and Mr. Bofwell's Tour, and his Life of that wonderful being, fo valuable to thofe who wifh not for an idol to worfhip, inftead of a great man to contemplate, as nature, paffion, and habit, compounded his character.

If thofe biographers had invefted their deceafed friend with excellence, which no fombre irritability had ever overfhadowed;with juftice and candor, which no literary jealoufy, no party prejudice, no bigot zeal had ever warped;-the public might have been led, through boundlefs veneration of one, into injuftice towards many. The world might have been induced to believe that all whofe merit he has depreciated, whofe talents he has undervalued, through the courfe of his Lives of the Poets, had deferved the fate they met on thofe pages. Then, to the injury of our national tafte, and to the literary and moral character of the great Englifh Claffics, more univerfal 
confidence had been placed in the fophiftries of thofe volumes, which feem to have put on the whole armor of truth by the force of their eloquence and the wit of their fatire.

A paragraph which appeared in feveral of the late newfpapers, and which contained a ridiculoufly falfe print, political for poetical, mentioned that thefe expected Memoirs were undertaken at the requeft of the late Dr. Darwin's family. A miftaken rumour; though they certainly had their rife in the expreffed defire of Dr. Robert Darwin of Shrewfoury, that I would fupply him with fuch anecdotes of his father's earlier life, as my intimacy with him, during that period, had enabled me to obtain, and which might affift in forming a biographic fketch, to be prefixed to his writings at fome future time. In purpofed obedience thefe records were begun, but they became too extended to form only materials for another perfon's compofition; 
and too impartial to pafs with propriety through the filial channel, though fervently juit to the excellencies of the commemorated.

Of thofe years in which the talents and focial virtues of this extraordinary man thed their luftre over the city which I inhabit, no hiftorian remains, who, with vicinity of habitation, and domeftic intercourfe with Dr. Darwin, took equal intereft with myfelf in all that marked, by traits of him, that period of twenty-three years, and which engaged my attention from $m y$ very earlieft youth. Some few of his contemporaries in this town yet remain; but not one who could be induced to publifh what their obfervation may have traced, and their memory treafured.

His fometime pupil, and late years friend, the ingenious Mr. Bilsborrow, is writing, or has written, his Life ; but fince Dr. Darwin conftantly fhrunk with referved pride from all that candor would 
deem confidential converfation, and which the world is fo apt to ridicule as vain egotifm; fince it is underftood that he has not left biographic documents; fince Mr. Bilfborrow was fcarcely in exiftence when his illuftrious friend firft changed his fphere of action; he muft find himfelf as much a ftranger to the particulars of his Lichfield refidence, as I am of thofe which were moft prominent in the equal number of years he paffed at Derby. Between us, all will probably be known that can now with accuracy be traced of Dr. Darwin.

To the beft of my power I have prefumed to be the recorder of vanifhed Genius, beneath the ever-prefent confcioufnefs that biography and criticifm have their facred duties, alike to the deceafed, and to the public; precluding, on one hand, unjuft depreciation, on the other, over-valuing partiality. 


\title{
MEMOIRS
}

\author{
of \\ THE LIFE AND WRITINGS \\ b. OF \\ DOCTOR DARWIN.
}

\section{CHAP. I.}

Doctor Erasmus Darwin was the fon of a private gentleman, near Newark, in Nottinghamfhire. He came to Lichfield to practife phyfic in the autumn of the year 1756 , at the age of twenty-four; bringing high recommendations from the univerfity of Edinburgh, in which he had ftudied, and from that of Cambridge, to which he belonged.

He was fomewhat above the middle fize, his form athletic, and inclined to corpulence; his limbs too heavy for exact pro- 
portion. The traces of a fevere fmall-pox; features, and countenance, which, when they were not animated by focial pleafure, were rather faturnine than fprightly; a ftoop in the fhoulders, and the then profeffional appendage, a large full-bottomed wig, gave, at that early period of life, an appearance of nearly twice the years he bore. Florid health, and the earnest of good humour, a funny fmile, on entering a room, and on first accorting his friends, rendered, in his youth, that exterior agreeable, to which beauty and fymmetry had not been propitious.

He ftammered extremely; but whatever he faid, whether gravely or in jest, was always well worth waiting for, though the inevitable impreffion it made might not always be pleafant to individual felf-love. Confcious of great native elevation above the general ftandard of intellect, he became, early in life, fore upon oppofition, whether 
in argument or conduct, and always revenged it by farcafm of very keen edge. Nor was he lefs impatient of the fallies of egotifm and vanity, even when they were in fo flight a degree, that ftrict politenefs would rather tolerate than ridicule them. Dr. Darwin feldom failed to prefent their caricature in jacofe but wounding irony. If thefe ingredients of colloquial defpotifm were difcernible in unworn exiftence, they increafed as it advanced, fed by an evergrowing reputation within and without the pale of medicine.

Extreme was his feepticifm to human truth. From that caufe he often difregarded the accounts his patients gave of themfelves, and rather chofe to collect his information by indirect inquiry and by crofs-examining them, than from their voluntary teftimony. That diftruft and that habit were probably favourable to his fkill in difcovering the origin of difeafes, and

thence 
thence to his preeminent fuccefs in effecting their cure;-but they imprefled his mind and tinctured his converfation with an apparent want of confidence in mankind, which was apt to wound the ingenuous and confiding fpirit, whether feeking his medical affiftance, or his counfel as a friend. Perhaps this pronenefs to fufpicion mingled too much of art in his wisdom.

From the time at which Dr. Darwin firft came to Lichfield, he avowed a conviction of the pernicious effects of all vinous fluid on the youthful and healthy conftitution; an abfolute horror of fpirits of all forts, and however diluted. His own cxample, with very few exceptions, fupported his exhortations. From ftrong malt liquor he totally abfained, and if he drank a glafs or two of Englinh wine, he mixed it with water. Acid fruits, with fugar, and all fort of creams, and butter, were his fuxuries; but he always ate plentifully of animal 
animal food. This liberal alimentary regimen he prefcribed to people of every age, where unvitiated appetite rendered them capable of following it ; even to in- fants. He defpifed the prejudice, which deems foreign wines more wholefome than the wines of the country. If you muft. drink wine, faid he, let it be home-made. It is well known, that Dr. Darwin's influence and example have fobered the county of Derby; that intemperance in fermented fluid of every fpecies is almoft unknown amongft it's gentlemen.

Profeffional generofity diftinguifhed Dr. Darwin's medical practice. While refident in Lichfield, to the prieft and lay-vicars of it's cathedral, and their families, he always cheerfully gave his advice, but never took fees from any of them. Diligently, alfo, did he attend to the health of the poor in that city, and afterwards at Derby, and fupplied their neceffities by food, and all sort 
of charitable affiftance. In each of thofe towns, his was the cheerful board of almoft open-houfed hofpitality, without extrava, gance or parade; deeming ever the firft unjuft, the latter unmanly. Generofity, wit, and fcience, were his houfehold gods.

To thofe many rich prefents, which Nature beftowed on the mind of Dr. Darwin, fhe added the feducing, and often dangerous gift of a highly poetic imagination; but he remembered how fatal that gift profeffionally became to the young phyficians, Akenfide and Armftrong. Concerning them, the public could not be perfuaded, that fo much excellence in an ornamental fcience was compatible with intenfe application to a feverer ftudy; with fuch application as it held neceffary to a refponfibility, towards which it might look for the fource of difeafe, on which it might lean for the ftruggle with mortality. Thus, through the firf twentythree years of his practice as a phyfician, 
Dr. Darwin, with the wifdom of Ulyfles, bound himfelf to the medical maft, that he might not follow thofe delufive fyrens, the mufes, or be confidered as their avowed votary. Occafional little pieces, however, ftole at feldom occurring periods from his pen; though he cautiouny precluded their paffing the prefs, before his latent genius for poetry became unveiled to the public eye in it's copious and dazzling fplendour. Moft of thefe minute gems have ftolen into newfpapers and magazines, fince the impregnable rock, on which his medicinal and philofophical reputation were placed, induced him to contend for that fpecies of fame, which Thould entwine the Parnaffian laurel with the balm of Pharmacy:

After this fketch of Dr. Darwin's character and manners, let us return to the dawn of his profeffional eftablifhment. A few weeks after his arrival at Lichfield, in the latter end of the year 1756 , the intuitive 
difcernment, the fkill, fpirit, and decifion, which marked the long courfe of his fuccefsful practice, were firft called into action, and brilliantly opened his career of fame. The late Mr. Inge of Thorpe, in Staffordfhire, a young gentleman of family, fortune, and confequence, lay fick of a dangerous fever. The juftly celebrated Dr. Wilks of Willenhal, who had many years poffeffed, in wide extent, the bufinefs and confidence of the Lichfield neighbourhood, attended Mr. Inge, and had unfuccefsfully combated his difeafe. At length he pronounced it hopelefs; that fpeedy death muft enfue, and took his leave. It was then that a fond mother, wild with terror for the life of an only fon, as drowning wretches catch at twigs, fent to Lichficld for the young, and yet inexperienced phyfician, of recent arrival there. By a reverfe and entirely novel courfe of treatment, Dr. Darwin gave his dying, patient back to exiftence, to health, 
health, profperity, and all that high reputation, which Mr. Inge afterwards poffefed as a public magiftrate.

The far-fpreading report of this judicioufly daring and fortunate exertion broughit Dr. Darwin into immediate and extenfive employment, and foon eclipfed the hopes of an ingenious rival, who refigned the conteft; nor, afterwards, did any other competitor bring his certainly ineffectual lamp into that fphere, in which fo bright a luminary thone.

Equal fuccers, as in the cafe of Mr. Inge, continued to refult from the powers of Dr. Darwin's genius, his frequent and intenfe meditation, and the avidity with which he, through life, devoted his leifure to fcientific acquirement, and the invertigation of difeafe. Ignorance and timidity, fuperfition, prejudice, and envy, feduloufly ftrove to attach to his practice the terms, rafh, experimental, theoretic; not confidering, that without 
without experimental theory, the reftoring fcience could have made no progrefs; that neither time, nor all it's accumulation of premature death, could have enlarged the circle, in which the merely practical phyfician condemns himfelf to walk. Strength of mind, fortitude unappalled, and the perpetual fuccefs which attended this great man's deviations from the beaten track, enabled him to thake thofe mifts from his xeputation, as the lion shakes to air the dewdrops on his mane.

In 1757, he married Mifs Howard, of the Clofe of Lichfield, a blooming and lovely young lady of eighteen. A mind, which had native ftrength; an awakened tafte for the works of imagination; ingenuous fweetnefs; delicacy animated by sprightlinefs, and furtained by fortitude, made her a capable, as well as fafcinating companion, even to a man of talents fo ilIuftrious.-To her he could, with confidence, 
dence, commit the important tafk of rendering his children's minds a foil fit to receive, and bring to fruit, the ftamina of wifdom and fcience.

Mrs. Darwin's own mind, by nature fo well endowed, ftrengthened and expanded in the friendhip, converfation, and confidence of fo beloved, fo revered a preceptor. But alas! upon her early youth, and a too delicate conftitution, the frequency of her maternal fituation, during the firft five years of her marriage, had probably a baneful effect. The potent fkill, and affiduous cares of him, before whom difeafe daily vanifhed from the frame of others, could not expel it radically from that of her ho loved. It was however kept at bay thirteen years.

Upon the diftinguifhed happinefs of thofe years, the fpoke with fervour to two intimate female friends in the laft week of her exiftence, which clofed at the latter end of the 
the fummer 1770 . "Do not weep for $m y$ " impending fate," faid the dying angel, with a fmile of unaffected cheerfulners. "In the fhort term of my life, a great "deal of happinefs has been comprifed. "The maladies of my frame were peculiar; " the pains in my head and ftomach, which " no medicine could eradicate, were fpar" modic and violent; and required ftronger " meafures to render them fupportable "while they lafted, than my conftitution " could fuftain without injury.- The pe" riods of exemption from thofe pains were " frequently of feveral days duration, and " in my intermiffions I felt no indication " of malady. Pain taught me the value of " eafe, and I enjoyed it with a glow of " fpirit, feldom, perhaps, felt by the habi" tually healthy. While Dr. Darwin com"bated and affuaged my difeafe from time " to time, his indulgence to all my winhes, " his active defire to fee me amufed and "s happy, 
" happy, proved inceffant. His houfe, as "you know, has ever been the refort of "people of fcience and merit. If, from "'my huband's great and extenfive prac"tice, I had much lefs of his fociety than "I withed, yet the converfation of his "friends, and of my own, was ever ready " to enliven the hours of his abfence. As "occafional malady made me doubly enjoy "health, fo did thofe frequent abfences " give a zeft, even to delight, when I could "be indulged with his company. My "three boys have ever been docile, and "affectionate.-Children as they are, I "could truft them with important fecrets, "fo facred do they hold every promife they " make. They fcorn deceit, and falfehood "of every kind, and have lefs felfinhnefs "than generally belongs to childhood."Married to any other man, I do not fup"pofe I could have lived a third part of st thofe years, which I have paffed with

" Dr.Dar- 
"Dr. Darwin; he has prolonged my days, " and he has bleffed them."

Thus died this fuperior woman, in the bloom of life, fincerely regretted by all, who knew how to value her excellence, and pafs fionately, regretted by the felected few, whom The honoured with her perfonal and confidential friendfhip. The year after his marriage, Dr. Darwin purchafed an old half timbered houfe in the cathedral vicarage, adding a handfome new front, with venetian windows, and commodious apartments. This front looked towards Beacon ftreet, but had no ftrect annoyance, being feparated from it by a narrow, deep, dingle, which, when the Doctor purchafed the premifes, was overgrown with tangled briars and knot-grafs. In ancient days it was the receptacle of that water; which moated the Clofe in a femicircle, the other half being defended by the Minfter pool. A fortunate opening, between the oppofite houfes 
and this which has been defcribed, gires it a profpect, fufficiently extenfive, of pleafant and umbrageous fields. Acrofs the dell, between his houfe and the ftreet, Dr. Darwin flung a broad bridge of thallow fteps with chinefe paling, defcending from his hall-door to the pavement. The tangled and hollow bottom he cleared into lawny fmoothnefs, and made a terrace on the bank, which ftretched in a line, level with the floor of his apartments, planting the fteep declivity with lilacs and rofe-bufhes; while he fcreened his terrace from the gaze of paffengers, and the fummer fun,

"By all that higher grew,
"Of firm and fragrant leaf. Then fwiftly rofe
"Acanthus, and each odorous, bufhy Thrub,
"To fence the verdant wall."

The laft gentleman who purchafed this houfe and it's gardens, has deftroyed the verdure and plantations of that dell, for the 
purpofe of making a circular coach-road from the freet to the hall-door; a facrifice of beauty to convenience, and one of many proofs, that alteration and improvement are not always fynonimous terms. To this rus in urbe, of Darwinian creation, reforted, from it's early rifing, a knot of philofophic friends, in frequent vifitation. The Rev.Mr. Michell, many years deceafed. He was fkilled in aftronomic fcience, modeft and wife. The ingenious Mr. Kier, of Weft Bromich, then Captain Kier. Mr. Boulton, known and refpected wherever mechanic philofophy is underftood. Mr. Watt, the celebrated improver of the fteam engine. And, above all others in Dr. Darwin's perfonal regard, the accomplifhed Dr. Small, of Birmingham, who bore the blufhing honours of his talents and virtues to an untimely grave.

About the year 1765 , came to Lichfield, from the neighbourhood of Reading, the young and gay philofopher, Mr. Edgeworth, 
worth, a man of fortune, and recently married to a Mifs Ellars of Oxfordhire. The fame of Dr. Darwin's various talents allured Mr. E. to the city they graced. Then fcarcely two and twenty, and with an exterior yet more juvenile, he had mathematic fcience, mechanic ingenuity, and a competent portion of claffical learning, with the poffeffion of the modern languages. His addrefs was gracefully fpirited, and his converfation eloquent. $\mathrm{He}$ danced, he fenced, and winged his arrows with more than philofophic fkill; yet did not the confcioufnefs of thefe lighter endowments abate his ardour in the purfuit of knowledge.

After having eftablifhed a friendfhip and correfpondence with Dr. Darwin, Mr.Edgeworth did not return to Lichfield till the fummer of the year 1770 . With him, at that period, came the late Mr. Day, of Bear-hill, in Berkfhire. Thefe young men had been fellow-ftudents in the university 
of Oxford. Mr. Day was alfo attracted by the fame celebrated abilities, which, five years before, had drawn his friend into their fphere. He was then twenty-four, in poffeffion of a clear eftate, about twelve hundred pounds per annum.

Mr. Day looked the philofopher. Powder and fine clothes were, at that time, the appendages of gentlemen. Mr. Day wore not either. He was tall and ftooped in the fhoulders, full made, but not corpulent; and in his meditative and melancholy air a degree of awkwardnefs and dignity were blended. We found his fentures interefting and agreeable amidft the traces of a fevere fmall-pox. There was a fort of weight upon the lids of his large hazle eyes; yet when he declaimed,

\section{"Of good and evil,}

"Paffion, and apathy, and glory, and thame,"

very expreflive were the energies gleaming from 
from them beneath the fhade of fable hair, which, Adam-like, curled about his brows. Lefs graceful, lefs amufing, lefs brilliant than Mr. E., but more highly imaginative, more claffical, and a deeper reafoner; ftrict integrity, energetic friendfhip, openhanded bounty, fedulous and diffufive charity, greatly overbalanced, on the fide of virtue, the tincture of mifanthropic gloom and proud contempt of common-life fociety, that marked the peculiar character, which fhall unfold itfelf on thefe pages. In fucceeding years, Mr. Day publifhed two noble poems, The Dying Negro, and The Devoted Legions; alfo Sandford and Merton, which by wife parents is put into every youthful hand.

Mr. Day dedicated the third edition of The Dying Negro to Rouffeau. That dedication has every force and every grace of eloquence. The fentiments are ftrongly characteriftic of their writer, except in the 
philippic againft American refiftance; juft commenced when the addrefs to Roufleau was compofed. Generous indignation of the flave trade, practifed without remorfe in the fouthern colonies of North America, induced Mr. Day to refure them all credit for the patriotic virtue of that refiftance to new and unconftitutional claims, which threatened their liberties.

In the courfe of the year $1570, \mathrm{Mr}$. Day ftood for a full-length picture to Mr. Wright of Derby. A ftrong likenefs and a dignified portrait were the refult. Drawn as in the open air, the furrounding fky is tempeftuous, lurid, and dark. He ftands leaning his left arm againft a column infcribed to Hambden. Mr. Day looks upward, as enthufiaftically meditating on the contents of a book, held in his dropped right hand. The open leaf is the oration of that virtuous patriot in the fenate, againft the grant of mip-money, demanded by King

Charles 
Charles the firft. A flafh of lightning plays in Mr. Day's hair, and illuminates the contents of the volume. The poetic fancy, and what were then the politics of the original, appear in the choice of fubject and attitude. Dr. Darwin fat to Mr. Wright about the fame period. That was a fimply contemplative portrait, of the moft perfect refemblance.

During the fummer and autumn of that year, was found, in Dr. Darwin's circle, as Mr. Day's vifitor, the late Mr. William Seward of London; yet, though a young man whofe talents were confiderably above the common level, he was rather a fatellite than a planet in that little fpherè. He afterwards became known to the literary world as one of Dr. Johnfon's habitual companions, and, in the year 1795, he publiphed Anecdotes of Diftinguifhed Perfons; a compilation of more induftry in the collection, than grace in 
the drefs. Mr. W. Seward has not difplayed in thofe volumes, the happy art of animating narration. Common occurrences; even in the lives of eminent people, weary attention, unlefs they are told with elegance and firit. From the ardently fought fociety of men of genius, this gentleman acquired a ftriking degree of wit and ingenious allufion in converfation, though it was too uniformly, and too cauftically, of the farcaftic fpecies; but every fort of fire feems to have evaporated from the language of Mr. W. Seward in paffing through his pen.

Mr. Day and Mr. Edgeworth took the houfe now inhabited by Mr. Morelby, in the little green valley of Stow, that nopes from the eaft end of the cathedral, and forms, with it's old grey tower on the banks of it's lake, fo lovely a landfcape. That houfe was Mr. Day's bachelor manfion through the year I 770 ; that of Mr. Edge- 
Edgeworth, and his wife and family, in the enfuing year. All of this city and it's vicinity, who comprehended and tafted thofe powers of mind which take the Jigher range of intellect, were delighted to mingle in fuch affociation.

In February 1775, died Dr. Small, nor were fo much talent and merit fuffered to pafs away

"Without the meed of fome melodious tears."

They were given in a fhort elegy, by his moft valued friend, Dr. Darwin; which slegy is engraven on a vafe in Mr. Boulton's garden, facred to the memory of the ingenious deceafed.

Ye Gay, and Young, who thoughtlefs of your doom, Shun the difguffiful manfions of the dead, Where Melancholy broods o'er many a tomb, Mouldering beneath the yew's uuwholcome fhade, 
If chance ye enter thefe fequefter'd groves, And day's bright funthine, for a while, forego,

O leave to Folly's cheek, the laughs and loves, And give one hour to philofophic woe!

Here, while no titled duft, no fainted bone,

No lover, weeping over beauty's bier, No warrior, frowning in hiftoric ftone,

Extorts your praifes, or requefts your tear,

Cold Contemplation leans her aching head,

And as on human woe her broad eye turns, Waves her meek hand, and fighs for fcience dead,

For fcience, virtue, and for Small the mourns!

\section{Epitaph on Dr. Small of Birmingham, by Mr. Day.}

Beyond the rage of Time, or Fortune's power, Remain, cold ftone!-remain, and mark the hour When all the nobleft gifts that Heaven e'er gave Were deftined to a dark, untimely grave.

$O$ taught on reafon's boldeft wing to rife, And catch each glimmer of the opening fkies !

$O$ gentle bofom ! $O$ unfpotted mind!

$O$ friend to truth, to virtue, and mankind, Thy lov'd remains we truft to this pale fhrine, Secure to meet no fecond lofs like thine! 
In Mr. Day's epitaph there is fome pathos, and more poetry ; but it is far from being faultlefs. Perhaps it may be it's leaft error, that the name of the bewailed is omitted, which Dr. Johnfon has well obferved, ought always to be involved in the verfes. It muft, however, be confeffed, that, in this cafe, the noun perfonal was not calculated to appear with grace in verfe; but that confideration, though it doubtlefs caufed, will not jufify, the omiffion. In Dr. Darwin's Elegy, it is placed out of all poffibility of ludicrous equivoque, and $\int_{0}$ accents the laft line, as to produce no mean or inharmonious found. The commendation, alfo, is, in the elegy, of much more dignified modefty. Praife may be allowed to glow even upon a tombftone, but fhould never be hyperbolic. The epitaph is too exclamatory; and to affert that no fecond lors, fo deplorable, can be furtained, is infinitely too much for one, who, how- 
ever endowed and adorned, left the world at large no written teftimony of that imputed fuperiority. It is finely obferved by the charming Prior,

"That the diftinguifh'd part of men, By pencil, compafs, fword, or pen, Should, in life's vifit leave their name, In characters, which may proclaim That they, with ardour, ftrove to raife At once their art, and country's praife; And, in the working, took great care That all was full, and round, and fair."

The circumftances of Mr. Day's difpofition, habits, and deitiny were fo peculiar, as to juftify digreffion from the principal fubject of thefe pages. Their author would deem it inexcufable to introduce any thing fabulous; to embellifh truth by the fighteft colouring of fiction, even by exaggerating fingu-

- larity, or heightening what is extraordinary; - but when realities are of a nature to intereft and to amufe in a collateral branch of the memoir, 
memoir, the reader will not be difpleafed to turn from it's principal perfonage, diftinguifhed rather by wonderful endowment than by uncommon occurrences, while the picture of his friend's more eventful ftory paffes before their eycs.

Mr. Day's father died during his infancy, and left him an eftate of twelve hundred pounds per annum. Soon after his mother married a gentleman of the name of Philips. The author of this narrative has often heard Mr. Day defcribe him as one of thofe common characters, who feek to fupply their inherent want of confequence, by a bufy teizing interference in circumftances, with which they have no real concern.

Mrs. Philips, jointured with three hundred pounds a year out of her fon's eftate, was left his fole guardian, or united with another perfon in the trust, whom fhe influenced. Herfelf, influenced by fuch a hufband, 
hubband, often rendered uncomfortable the domeftic fituation of a high-fpirited youth of genius. We may well fuppofe he impatiently brooked the preceptive impertinence, and troublefome authority of a man whom he defpifed, and who had no claim upon his obedience, though he confidered it as a duty to pay fome outward refpect to the hufband of his mother.

She frequently repined at the narrownefs of her jointure, and ftill oftener expreffed folicitude left Mr. Philips, who had no fortune of his own, fhould lofe in the decline of life, by lofing her, all comfortable fubfiftence. It was Mr. Day's firft act, on coming of age, and into poffeffion of his eftate, to augment his mother's jointure to four hundred, and to fettle it upon Mr. Philips during his life. This bounty, to a man who had needlefsly mortified and embittered fo many years of his own infancy and youth, evinced a very clevated 
elevated mind. That mind had alfo been wounded by the caprice of a young lady, who "claimed the triumph of a lettered " heart," without knowing how to value and retain her prize. Before the proofs of her ficklenefs became indifputable, he wrote the following beautiful elegy?

Yet once again, in yonder myrtle bowers, Whence rofe-lipp'd zephyrs, hovering, thed perfume,

I weave the painted radiance of the flowers, And prefs coy Nature in her days of bloom.

Shall the, benignant, to the wondering eyes Of the lone hermit all her charms unfold? Or, gemm'd with dew, bid her gay florets rife To grace the ruftic mafter of the fold?

Shall thefe poffefs her bright, her fragant ftore, Thefe fnatch the wreath, by plaftic Nature wove, Nor wanton fummer yield one garland more To grace the bofom of the nymph I love?

For the thall come; with her each fifter grace,

With her the kindred powers of harmony, The deep recelfes of the grove fhall trace, And hang with flowers each confecrated tree. 
Blithe Fancy too Mall fpread her glittering plumes,

She loves the white cliffs of Britannia's inle,

She loves the fpot where infant Genius blooms,

She loves the fpot, where Peace and Freedom fmile.

Unlefs her aid the mimic queen beftow;

In vain freth garlands the low vales adorn;

In vain with brighter tints the florets glow,

Or dewdrops fparkle on the brow of morn.

Opes not one bloffom to the ficy gale,

Throws not one elm it's mofs-wreath'd branches wide, Wanders no rill through the luxuriant vale,

Or, glif'ning, rufhes down the mountain fide,

But thither, with the morning's earlieft ray,

Fancy has wing'd her ever-mazy flight,

To hymn wild carols to returning day,

And catch the faireft beams of orient light.

Proud of the theft the mounts her lucid car,

Her car the rainbow's painted arch fupplies;

Her fwift wing'd fteeds unnumber'd loves prepare,

And countlefs zephyrs waft her through the fkies.

There, while her bright wheels paufe in cloudlefs air,

She waves the magic fceptre of command,

And all her flattering vifions, wild as fair,

Start into life beneath the potent wand. 
Here, proudly nodding o'er the vale below,

High rocks of pearl reflect the morning ray, Whence gurhitg freams of azure nectar flow, And tinge the trickling herbage on their way.

Thefe, culld from every mountain, every plain,

Perennial flowers the ambient air perfume, Far off flern Boreas holds his drear domain, Nor chains the ftreams, nor blights the facred bloom.

Through all the year, in copfe and tangled dale,

Lone Philomel her fong to Venus pours,

What time pale Evening fpreads the dewy veil,

What time the red Morn blufhes on the fhores.

Illufive vifions ! $O$, not here,-not here,

Does Spring eternal hold her placid reign,

Already Boreas chills the altering year,

And blafts the purple daughters of the plain.

So fade my promis'd joys - - fair fcenes of blifs,

Ideal fcenes, too long believ'd in vain,

Plung'd down and fivallow'd deep in Time's abyis I-

So reering Chance, and ruthlefs fates ordain.

Thee, Laura, thee, by fount, or mazy ftreạm,

Or thicket rude, unprefs'd by human feet, I figh, unheeded, to the moon's pale beam;

Thee, Laura, thee, the echoing hills repeat. 
Oh ! long of billow's wild, and winds the fport,

Seize, feize the fafe afylum that remains!

Here Truth, Love, Freedom, Innocence refort, And offer long oblivion to thy pains.

When panting, gafping, breathlefs, on the ftrand

The Mipwreck'd mariner reclines his breaf,

Say, thall he fcorn the hofpitable hand,

That points to fafety, liberty, and reft ?

But thiou, too foon forgetful of paft woe,

Again would'ft tempt the winds, and treacherous fea;

$\mathrm{Ab}$ ! fhall the raging blaft forget to blow,

Shall every wintry ftorm be hufh'd for thee ?

Not fo! I dread the elemental war,

Too foon, too foon the calm, deceitful, flies;

I hear the blaft come whifling from afar,

I fee the tempeft gathering in the fkies.

Yet let the tempef roar!-love fcorns all harms,

I plunge amid the ftorm, refolved to fave;

-This hour, at leaft, I clafp thee in my arms,

The next let ruin join us in the grave.

The above verfes imply fome perfidy, or difappointment experienced by the lady to whom 
whom they are addreffed. She probably accepted Mr. Day's addreffes in refentment, and afterwards found the had not a heart to give him. This is no uncommon cafe; and it is furely better to recede, even at the church-porch; than to plight at it's altar the vow of unexifting love, which no effort of the will can implant in the bofom. It has been obferved, that marriage is often the grave of love, but fcarcely ever it's cradle; and what hope of happinefs, what hope of a bleffing on nuptials, which commence with perjury!

Even at that period, "when youth, elate and gay, fteps into life," Mr. Day was a rigid moralift, who proudly impofed on himfelf cold abftinence, even from the moft innocent pleafures; nor would he allow an action to be virtuous, which was performed upon any hope of reward, here, or hereafter. This feverity of principle, more abftract and fpecious, than natural 
or ufeful, rendered Mr. Day fceptical towards revealed religion, though by no means a confirmed deift. Moft unlike Doctor Johnfon in thofe doubts, he refembled him in want of fympathy with fuch miferies as fpring from refinement and the fofter affections; refembled him alfo, in true compaffion for the fufferings of cold and hunger. To the power of relieving them he nobly facrificed all the parade of life, and all the pleafures of luxury. For that mafs of human character which conftitutes polifhed fociety, he avowed a fovereign contempt; above all things he expreffed averfion to the modern plans of female education, attributing to their influence the fickleness which had ftung him. He thought it, however, his duty to marry; nurfed fyftematic ideas of the force of philofophic tuition to produce future virtue, and loved to mould the infant and youthful mind. 
Ever defpicable in Mr. Day's eftimation were the diftinctions of birth, and the advantages of wealth; and he had learnt to look back with refentment to the allurements of the Graces. He refolved, if poffible, that his wife thould have a tafte for literature and fcience, for moral and patriotic philofophy. So might fhe be his companion in that retirement, to which he had deftined himfelf; and affift him in forming the minds of his children to ftubborn virtue and high exertion. He refolved alfo, that the thould be fimple as a mountain girl, in her drefs, her diet, and her manners ; fearlefs and intrepid as the Spar$\tan$ wives and Roman heroines.-There was no finding fuch a creature ready made; philofophical romance could not hope it. He muft mould fome infant into the being his fancy had imaged.

With the late Mr. Bicknel, then a barrifter, in confiderable practice, and of

$$
\text { D } 2 \text { taintlefs }
$$


taintlefs reputation, and feveral years older than himfelf, Mr. Day lived on terms of intimate friendhip. Credentials were procured of Mr. Day's moral probity, and with them, on his coming of age, thefe two friends journied to Shrewnbury, to explore the hofpital in that town for foundling girls. From the little train, Mr. Day, in the prefence of Mr. Bicknel, felected two of twelve years each; both beautiful; one fair, with flaxen locks, and light eyes; her he called Lucretia. The other, a clear, auburn brunette, with darker eyes, more glowing bloom, and chefnut treffes, he named Sabrina.

Thefe girls were obtained on written conditions, for the performance of which Mr. Bicknel was guarantce. They were to this effect; that Mr. Day hould, within the twelvemonth after taking them, refign one into the protection of fome reputable tradefwoman, giving one hundred pounds 
to bind her apprentice; maintaining her, if the behaved well, till the married, or began bufinefs for herfelf. Upon either of thefe events, he promifed to advance four hundred more. He avowed his intention of educating the girl he fhould retain, with a view to making her his future wife; folemnly engaged never to violate her innocence; and if he thould renounce his plan, to maintain her decently in fome creditable family till the married, when he promifed five hundred pounds as her wedding portion.

$\mathrm{Mr}$. Day went inftantly into France with thefe girls; not taking an Englinh fervant, that they might receive no ideas, except thofe which himfelf might choofe to impart.

They teized and perplexed him; they quarrelled, and fought inceffantly: they fickened of the fmall-pox; they chained him to their bed-fide by crying, and 
fcreaming if they were ever left a moment with any perfon who could not fpeak to them in Englifh. He was obliged to fit up with them many nights; to perform for them the loweft offices of affiftance.

They loft no beauty by their difeafe. Soon after they had recovered, croffing the Rhone with his wards in a tempertuous day, the boat overfet. Being an excellent fwimmer he faved them both, though with difficulty and danger to himfelf.

Mr. Day came back to England in eight months, heartily glad to feparate the little fquabblers. Sabrina was become the favourite. He placed the fair Lucretia with a chamber milliner. She behaved well, and became the wife of a refpectable linen-draper in London. On his return to his native country, he entrufted Sabrina to the care of Mr. Bicknel's mother, with whom the refided fome months in a country village, while he fettled his affairs 
at his own manfion-houfe, from which he promifed not to remove his mother.

It has been faid before, that the fame of Dr. Darwin's talents allured Mr. Day to Lichfield. Thither he led, in the fpring of the year 1770, the beauteous Sabrina, then thirteen years old, and taking a twelve month's poffeffion of the pleafant manfion in Stowe Valley, refumed his preparations for implanting in her young mind the characteriftic virtues of Arria, Portia, and Cornelia. His experiments had not the fuccers he wirhed and expected. Her fpirit could not be armed againft the dread of pain, and the appearance of danger. When he dropped melted fealing-wax upon her arms the did not endure it heroically, nor when he fired piftols at her petticoats, which the believed to be charged with balls, could the help ftarting afide, or fupprefs her fcreams.

When he tried her fidelity in fecret-

$$
\text { 1) } 4
$$

keep- 
keeping, by telling her of well-invented dangers to himfelf, in which greater danger would refult from it's being difcovered that he was aware of them, he once or twice detected her having imparted them to the fervants, and to her play-fellows.

She betrayed an averfenefs to the ftudy of books, and of the rudiments of fcience, which gave little promife of ability, that fhould, one day, be refponfible for the education of youths, who were to emulate the Gracchi.

Mr. Day perfifted in thefe experiments, and fuftained their continual difappointment during a year's refidence in the vicinity of Lichfield. The difficulty feemed to lie in giving her motive to exertion, felf-denial, and heroifm. It was againft his plan to draw it from the ufual fources, pecuniary reward, luxury, ambition, or vanity. His watchful cares had precluded all knowledge of the value of money, the reputation of

beauty, 
beauty, and it's concomitant defire of ornamented drefs. The only inducement, therefore, which this lovely artlefs girl could have to combat and fubdue the natural preference, in youth fo bloffoming, of eafe to pain, of vacant fport to the labour of thinking, was the defire of pleafing her protector, though the knew not how, or why he became fuch. In that defire, fear had greatly the afcendant of affecition, and fear is a cold and indolent feeling.

Thus, after a feries of fruitlefs trials, Mr. Day renounced all hope of moulding Sabrina into the being his imagination had formed; and ceafing to behold her as his future wife, he placed her at a boardingfchool in Sutton-Coldfield, Warwickfhire. His truft in the power of education faltered; his averfion to modern elegance fubfided. From the time he firft lived in the Vale of Stowe, he had daily converfed with the beautiful Mifs Honora Sneyd of

Lichfield. 
Lichfield. Without having received a Spartan education, the united a difinterefted defire to pleafe, fortitude of fpirit, native ftrength of intellect, literary and fcientific tafte, to unfwerving truth, and to all the graces. She was the very Honora Sneyd, for whom the gallant and unfortunate Major Andre's inextinguifhable parfion is on poetic, as his military fame and haplefs deftiny are on patriot, record. $\mathrm{Pa}$ rental authority having diffolved the juvenile engagements of this diftinguißhed youth and maid, Mr. Day offered to Honora his philofophic hand. She admired his talents; the revered his virtues; the tried to fchool her heart into fofter fentiments in his favour. She did not fucceed in that attempt, and ingenuoufly told him fo. Her fifter, Mifs Elizabeth Sneyd, one year younger than herfelf, was very pretty, very fprightly, very artlefs, and very engaging, though countlefs degrees inferior to the endowed and adorned 
adorned Honora. To her the yet lovelucklefs fage transferred the heart, which Honora had with fighs refigned. Elizabeth told Mr. Day the could have loved him, if he had acquired the manners of the world, inftead of thofe auftere fingularities of air, habit, and addrefs.

$\mathrm{He}$ began to impute to them the ficklenefs of his firft love; the involuntary icinefs of the charming Honora, as well as that for which her fifter accounted. He told Elizabeth, that, for her rake, he would' renounce his prejudices to external refinements, and try to acquire them. He would go to Paris for a year, and commit himfelf to dancing and fencing mafters. He did fo; ftood daily an hour or two in frames, to forew back his fhoulders, and point his feet; he practifed the military gait, the farhionable bow, minuets, and cotillions; but it was too late; habits, fo long fixed, could no more than partially be 
overcome. The endeavour, made at intervals, and by vifible effort, was more really ungraceful than the natural ftoop, and unfafhionable air. The ftudied bow on entrance, the fuddenly recollected affumption of attitude, prompted the rifible inftead of the admiring fenfation; neither was the howy drefs, in which he came back to his fair one, a jot more becoming.

Poor Elizabeth reproached her reluctant but infuppreflive ingratitude, upon which all this labour, thefe facrifices had been wafted. She confeffed, that Thomas Day, blackguard, as he ufed jeftingly to style himfelf, les difpleafed her eye than Thomas Day, fine gentleman.

Thus again difappointed, he refumed his accuftomed plainnefs of garb, and neglect of his perfon, and went again upon the continent for another year, with purfuits of higher aim, more congenial to his talents and former principles. Returning 
to England in the year 1773 , he faw, that fpring, Mifs Honora Sneyd united to his friend Mr. Edgeworth, who was become a widower; and, in the year 1780 , he learned that his fecond love of that name, Mifs Elizabeth Sneyd, was alfo, after the death of Honora married to Mr. Edgeworth.

It was fingular that Mr. Day nould thus, in the courfe of feven years, find himfelf doubly rivalled by his moft intimate friend; but his own previounly renounced purfuit of thofe beautiful young women, Ieft him without either caufe or fenfations of refentment on their account.

From the year 1773 this hitherto loverenounced philofopher refided chiefly in London, and amid the fmall and feleet circle which he frequented there, often met the pretty and elegant Mirs Efther Mills of Derbyhire, who, with modern acquircments, and amongft modinh luxuries, 
fuited to her large fortune, had cultivated her underftanding by books, and her virtues by benevolence. The again unpolined ftoic had every charm in her eyes,

"She faw Othello's vifage in his mínd."

But, from indignant recollection of hopes fo repeatedly baffled, Mr. Day looked with diftruft on female attention of however flattering femblance; nor was it till after years of her modeft, yet tender devotion to his talents and merit, that he deigned to afk Mifs Mills, if the could, for his fake, refign all that the world calls pleafures; all it's luxuries, all it's oftentation... If, with him, the could refolve to employ, after the ordinary comforts of life were fupplied, the furplus of her affluent fortune in clothing the naked, and feeding the hungry; retire with him into the country, and fhun, through remaining 
exiftence, the infectious taint of human fociety.

Mr. Day's conftitutional fault, like poor Cowper's, feemed that of looking with fevere and difgufted eyes upon thofe venial errours in his fpecies, which are mutually tolerated by mankind. This ftain of mifanthropy was extremely deepened by his commerce with the world, reftrained as that commerce had ever been. Satiric, jealous, and difcerning, it was not eafy to deceive him; yet, in a few inftances, he was deceived by the appearance of virtues congenial to his own:

* For ncither man, nor angel can difcern

"Hypocrify, the ouly evil that walks

"Invifible, except to God alone."

To propofals fo formidable, fo fure to be rejected by a heart lefs than infinitcly attached, Mifs Mills gladly affented; but fomething more remained. Mr. Day infifted, 
fifted, that her whole fortune fhould be fettled upon herfelf, totally out of his prefent or future control; that if the grew tired of a fyftem of life fo likely to weary a woman of the world, the might return to that world any hour the chofe, fully cmpowered to refume it's habits, and it's pleafures.

They married, and retired into the country about the year 1780 , according to the beft recollection of the author of thefe memoirs. No carriage; no appointed ferrant about Mrs. Day's own perfon; no luxury of any fort. Múfic, in which the was a diftinguifhed proficient, was deemed trivial. She banifhed her harpfichord and mufic-books. Frequent experiments upon her temper, and her attachment, were made by him, whom the lived but to obey and love. Over thefe the often wept, but never repined. No wife, bound in the stricteft fetters, as to the incapacity of claiming 
claiming feparate maintenance, ever made more abfolute facrifices to the moft imperious hurband, than did this lady, whofe independence had been fecured, and of whom nothing was demanded as a duty.

Thus Mr. Day found, at laft, amid the very clais he dreaded, that of fafhionable women, a heart whofe paffion for him fupplied all the requifites of his high-toned expectations.

Some eight or ten years after his marriage, the life of this fingular being be: came, in its meridian, a victim to one of his uncommon fyftems. He thought highly of the gratitude, generofity, and fenfibility of horfes; and that whenever they were difobedient, unruly, or vicious, it was owing to previous ill ufage from men. He had reared, fed, and tamed a favourite foal. When it was time it fhould become ferviceable, difdaining to employ a horfebreaker, he would ufe it 
to the bit and the burthen himfelf. He was not a good horfeman. The animal difliking his new fituation, heeded not the foothing voice to which he had been accuftomed. He plunged, threw his mafter, and then, with his heels, ftruck him on the head an infantly fatal blow. If was faid that Mrs. Day never afterwards faw the fun; that the lay in bed, into the curtains of which no light was admitted during the day, and only rofe to ftray alone through her garden, when night gave her forrows congenial gloom. She furvived this adored hurband two years, and then died, broken-hearted, for his lors.

Ere the principal fubject of this biographic tract is refumed, the reader will not be forry to learn the future deftiny of Sabrina. She remained at fchool three years; gained the efteem of her inftructrefs; grew feminine, elegant, and amiable. This young woman proved one of many inftances 
that thofe modes of education, which have been fanctioned by long experience, are feldom abandoned to advantage by ingenious fyftem-mongers.

When Sabrina left fchool, Mr. Day allowed her fifty pounds annually. She boarded fome years near Birmingham, and afterwards at Newport, in Shrophire. Wherever the refided, wherever the paid vifits, the fecured to herfelf friends. Beautiful and admired, the paffed the dangerous interval between fixteen and twenty-five, without one reflection upon her conduct, one ftain upon her difcretion. Often the gueft of Dr. Darwin, and other of her friends in Lichfield, efteem and affection formed the tribute to her virtues.

Mr.Day correfponded with her parentally, but feldom faw her, and never without witneffes. Two years after his marriage, and in her twenty-fixth year, his friend, $\mathrm{Mr}$. Bicknel, propofed himfelf; that very $\mathrm{Mr}$. 
Bicknel, who went with Mr. Day to the Foundling Horpital at Shrewfbury, and by whofe furetyfhip for his upright intentions the governors of that charity permitted Mr. Day to take from thence that beauteous girl, and the young Lucretia.

Mr. Bicknel, high in practice as a barrifter, was generally thought an advantageous match for Sabrina. More from prudential, than impaffioned impulfe, did fhe accept his addreffes, yet became one of the moft affectionate, as well as the beft of wives. When Mr. Day's confent was anked by his protégée, he gave it in thefe ungracious words: "I do not refufe my confent to your marrying Mr. Bicknel; but remember you have not afked my advice." He gave her the promifed dower, five hundred pounds.

Mr. Bicknel, without patrimonial fortune, and living up to his profeffional income, did not fave money. His beloved 
wife brought him two boys. When the eldeft was about five years old, their father was feized with a paralytic ftroke, which, in a few weeks, became fatal. His charm. ing widow had no means of independent fupport for herfelf and infants. Mr. Day faid he would allow her thirty pounds annually, to affift the efforts which he expected the would make for the maintenance of herfelf and children. To have been more bounteous muft furely have been in his heart, but it was nat in his fyftem. Through the benevolent exertions of Mr. Harding, Solicitor General to the Queen, the fum of eight hundred pounds was raifed among the gentlemen of the bar for Mrs. Bicknel and her fons; the intereft to be the mother's during her life, and the principal, at her deceafe, to be divided between her.children.

That excellent woman has lived many years, and yet lives with the good Dr. E 3 Burney 
Burney of Greenwich, as his houfekeeper, and affiftant in the cares of his academy. She is treated by him, and his friends, with every mark of efteem and refpect due to a gentlewoman, and one whofe virtues entitle her to univerfal approbation. Her name was not in Mr. Day's will, but Mrs. Day continued the allowance he had made her, and bequeathed its continuance from her own fortune during Mrs. Bicknel's life. Mr. and Mrs. Day left no child.

Mr. Edgeworth, having alfo loft his third wife, Elizabeth, is now the hurband of a fourth, a daughter of the reverend Dr. Beaufort of Ireland, He had four children by his firft; a fon, who of late years died in America; Mifs Edgeworth, the celebrated writer of Stories for Children, and Moral Tales for Young People, \&c.; Mifs Anna, married to the ingenious Dr. Beddoes of Briftol ; and Mifs Emmeline, married to Mr. King, furgeon of the

fame 
fame place. Honora left him an infant girl and boy, when the died in the year I780. The former inherited her mother's name, her beauty, and her malady, and died of confumption at fixteen. The amiable fon yet lives, with fine talents, but infirm health. By his third wife, Elizabeth, he has feveral children; and by the prefent, two or three. From Mr. Edgeworth's large family elaborate fyftems of infantile education have proceeded: of them the author of thefe memoirs cannot fpeak, as the has never feen them. Other compofitions, which are faid to be humorous and brilliant, are from the fame fource. 
se

mathes and

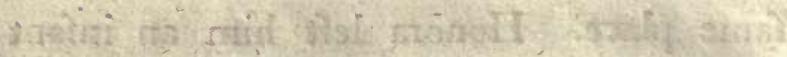

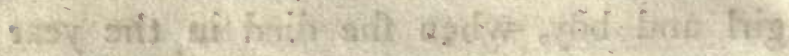

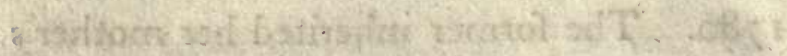

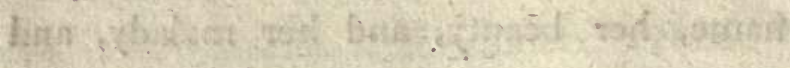
- ine sit2. :

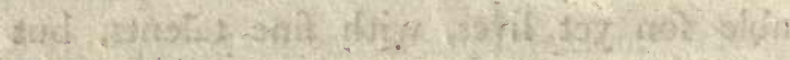

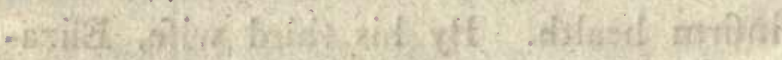

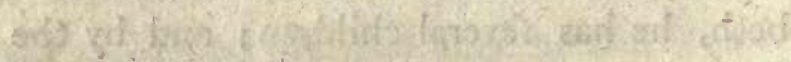

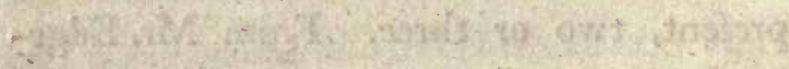

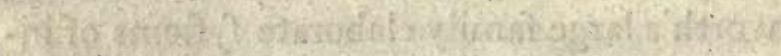

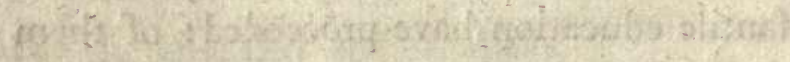

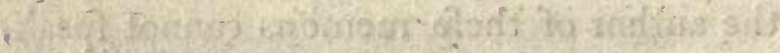

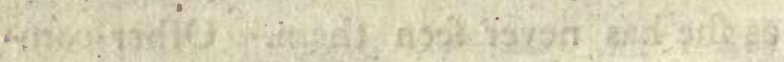

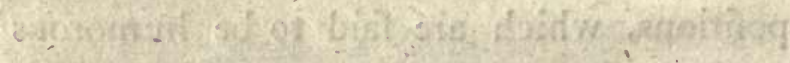

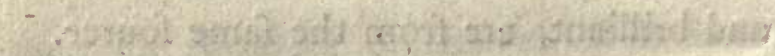

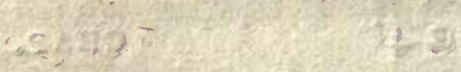




\section{CH A P T R II.}

Ir is now perhaps more than time to refume the recollected circumftances of Dr. Darwin's life.

After Dr. Small and Mr. Michell vanifhed from the earth, and Mr. Day and Mr. Edgeworth, in the year 1772 , left the Darwinian fphere, the prefent fir Brooke Boothby became an occafional inhabitant of Lichfield; fought, on every poffibility, the converfation of Dr. Darwin, and obtained his lafting friendnip. Sir Brooke had not lefs poetic fancy than Mr. Day, and even more external elegance than Mr. Edgeworth poffeffed when he won Honora's heart; elegance, which time, its 
general foe, has to this hour but little tarnifhed in the frame of fir Brooke Boothby.

A votary to botanic fcience, a deep reafoner, and a clear-fighted politician, is fir Brooke Boothby, as his convincing refutation of that fplendid, dazzling, and mifleading fophiftry, Burke on the French Revolution, has proved. Ever to be lamented is it, that national pride, and jealoufy, made our efficient fenate, and a large majority of people in thefe kingdoms, unable to difcern the fallacy which fir Brooke's anfwer unveiled. Fallacy, which has eventually overthrown the balance of power in Europe; built up, by the ftrong cement of oppofition, the Republic's menacing and commanding tower, and wafted in combat with the phantom, Jacobinifm, the nerves and finews of defence againft the time when real danger may affault Great Britain,

About the period at which fir Brooke firft fought Dr. Darwin, fought him, alfo, 
Mr. Munday of Marketon, whofe exertions, as a public magiftrate, have through life been moft benignly fedulous and wife; with whom

"The fair-ey'd Virtues in retirement dwell ;"

and whore ' Needwood Foreft' is one of the mort beautiful local poems that has been written. Its landfcapes vivid and appropriate; its epifodes fweet and interefting; its machinery well fancied and original; its numbers fpirited, correct, and harmonious; while an infufion of fweet and gentle morality pervades the whole, and renders it dear to the heart as to the eye and ear. Great is the lofs to poetic literature, that, of this delightful compofition, only a few copies were privately printed, for prefents to the author's friends and acquaintance; that he cannot overcome his reluctance to expore it to the danger of illiberal criticifm from fome of the felf-elected cenfors in cvery periodical publication. The public imagines, 
imagines, that, on éach fubject difcufied in a review and magazine, it obtains the joint opinion of a fet of learned men, employed to appreciate the value of publications. That in every fuch work many writers are engaged is true; yet is it no lefs true that in each feparate tract the opinion is merely individual on every various theme. One perfon is appointed to review the medical, another the chirurgical, another the clerical, another the hiftorical, another the philofophical articles, another the ethics in profe, and another the poetry; and each criticifes fingly, and unafyfted, in his appointed range.

The moft diftinguifhed of Dr.Darwin's fcientific friends, who vifited him from a diftance when he lived in Lichfield, have now been enumerated.

He once thought inoculation for the meafles might, as in the fmall-pox, materially foften the difeafe; and, after the patriotic example of lady Mary Wortley Montague, 
tague, he made the trial in his own family, upon his youngeft fon, Robert, now Dr. Darwin of Shrewibury, and upon an infant daughter, who died within her firft year. Each had, in confequence, the difeafe fo feverely, as to repel, in their father's mind, all future defire of repeating the experiment.

In the year $1 y 68$, Dr. Darwin met with an accident of irretrievable injury in the human frame. His propenfity to mechanics had unfortunately led him to conftruct a very fingular carriage. It was a platform, with a feat fixed upon a very high pair of wheels, and fupported in the front, upon the back of the horfe, by means of a kind of probofcis, which, forming an arch, reached over the hind quarters of the horfe; and paffed through a ring, placed on an upright piece of iron, which worked in a focket, fixed in the faddle. The horfe could thus move from one fide of the road to the other, quartering, as it is called, at the will of the driver, whofe conftant attention was necef- 
farily employed to regulate a piece of machinery contrived, but not well contrived, for that purpofe. From this whimfical carriage the Doctor was feveral times thrown, and the laft time he ufed it, had the miffortune, from a fimilar accident, to break the patella of his right knee, which caufed, as it always muft caufe, an incurable weak-

- nefs in the fractured part, and a lamenefs, not very difcernible indeed, when walking on even ground.

It is remarkable, that this uncommon accident happened to three of the inhabitants of Lichfield in the courfe of one year; firft, to the author of thefe memoirs in the prime of her youth; next, to Dr. Darwin; and, laftly, to the late Mr. Levett, a gentleman of wealth and confequence in the town. No fuch misfortune was previoufly remembered in that city, nor has it once recurred through all the years which have fince elapfed.

Dr. Darwin was happy in the talents, do- 
cility, and obedience, of his three fons. An high degree of ftammering retarded and embarraffed his utterance. The eldeft boy, Charles, had contracted the propenfity. With that wifdom, which marked the Doctor's obfervations on the habits of life; with that decifion of conduct, which always infantly followed the conviction of his mind, he fent Charles abroad; at once to break the force of habit, formed on the contagion of daily example, and from a belief, that in the pronunciation of a foreign language, hefitation would be lefs likely to recur, than in fpeaking thofe words and fentences, in which he had been accuftomed to hefitate. About his twelfth year he was committed to, the care of the fcientific, the learned, the modeft, and worthy Mr. Dickinfon, now, rector of Blimel, in Shrophire.

That the purpofe of the experiment might not be fruftrated, Dr. Darwin impreffed that good man's mind with the neceffity 
ceffity of not permitting his pupil to converfe in Englifh; nor ever to hear it uttered after he could at all comprehend the French language. Charles Darwin returned to England, after a two year's refidence on the continent, completely cured of ftammering; with which he was not afterwards troubled; but his utterance was, from that time, fomewhat thick and hurried.

Since thefe memoirs commenced, an odd anecdote of Dr. Darwin's early refidence at Lichfield was narrated to a friend of the author by a gentleman, who was of the party in which it happened. Mr. Sneyd, then of Bifhton, and a few more gentlemen of Staffordhire, prevailed upon the Doctor to join them in an expedition by water, from Burton to Nottingham, and on to Newark. They had cold provifion on board, and plenty of wine. It was midfummer; the day ardent and fultry. The noontide meal had been made, and the 
the glafs gone gayly round. It was one of thofe few inftances, in which the medical votary of the Naiads tranfgreffed his general and ftrict fobriety. If not abfolutely intoxicated, his fpirits were in a high ftate of vinous exhilaration. On the boat approaching Nottingham, within the diftance of a few fields, he furprifed his companions by ftepping, without any previous notice, from the boat into the middle of the river, and fwimming to fhore. They faw him get upon the bank, and walk coolly over the meadows toward the town: they called to him in vain, he did not once turn his head.

Anxious left he fhould take a dangerous cold by remaining in his wet clothes, and uncertain whether or not he intended to defert the party, they rowed inftantly to the town, at which they had not defigned to have touched, and went in fearch of their river-god.

In paffing through the market-place 
they faw him ftanding upon a tub, encircled by a crowd of people, and refifing the entreaties of an apothecary of the place, one of his old acquaintance, who was importuning him to go to his houfe, and accept of other raiments till his own could be dried.

The party, on preffing through the crowd, were furprifed to hear him fpeaking without any degree of his ufual ftammer.

" Have I not told you, my friend, that " I had drank a confiderable quantity of "s wine before I committed myfelf to the "river. You know my general fobriety; "s and, as a profeffional man, you ought sc to know, that the unufual exiftence of 66 internal ftimulus, would, in its effects " upon the fyftem, counteract the external "cold and moifture."

Then, perceiving his companions near him, he nodded, fmiled, and waved his hand, as enjoining them filence, thus, without hefitation, addreffing the populace. 
"Ye men of Nottingham, liften to me. "You are ingenious and induftrious me" chanics. By your induftry life's comforts " are procured for yourfelves and families. "If you lofe your health, the power of " being induftrious will forfake you. That " you know; but you may not know, that " to breathe frerh and changed air con"ftantly, is not lefs neceffary to preferve " health, than fobriety itfelf. Air becomes "unwholefome in a few hours if the win" dows are Thut. Open thofe of your "fleeping-rooms whenever you quit them. " to go to your workhops. Keep the " windows of your workihops open when" ever the weather is not infupportably "cold. I have no intereft in giving you " this advice. Remember what I, your " countryman, and a phyfician, tell you. "If you would not bring infection and " difeafe upon yourfelves, and to your "wives and little ones, change the air you 
" breathe, change it many times in a day, "by opening your windows."

So faying, he ftept down from the tub, and returning with his party to their boat, they purfued their voyage.

Dr. Johnfon was feveral times at Lichfield, on vifits to Mrs. Lucy Porter his daughter-in-law, while Dr. Darwin was one of its inhabitants. They had one or two interviews, but never afterwards fought each other. Mutual and frong diflike fubfifted between them. It is curious that in Dr. Johnfon's various letters to Mrs. Thrale, now Mrs. Piozzi, publinhed by that lady after his death, many of them, at different periods, dated from Lichfield, the name of Darwin cannot be found; nor indeed, that of any of the ingenious and lettered people who lived there; while of its mere common-life charaders there is frequent mention, with many hints of Lichfield's intellectual barrenners, 
rennefs, while it could boaft a Darwin, and other men of claffical learning, poetic talents, and liberal information.

Of that number was the Rev. Thomas Seward Canon-Refidentiary of its Cathedral; known to the lettered world as critical editor of Beaumont and Fletcher's Plays, in concert with Mr. Simpfon. Their edition came out in the year $175^{\circ}$. By people of literary tafte and judgment, it is allowed to be the beft commentary on thofe dramatic poets which has appeared; and that from the lucid ability of Mr. Seward's readings and notes. Strange, that dramas, fo entirely of the Shakefperian fchool, in the bufinefs and intereft of their plots; in the ftrength and variety of their characters; and which, in their fentiments and language, poffefs fo much of Shakefpeare's fire, fhould be coldly and ftupidly neglected in the prefent day, which has not yet forgotten to proclaim the Bard of Avon to be, what he furely is, the firft 
poet the world has produced. Shakefpeare has had few more fpirited eulogifts than Mr. Seward, in the following lines, written about the year $174^{\circ}$, and publifhed, together with other little poems of his, in Dodfley's Mifcellany.

Great Homer's birth feven rival cities claim,

Too mighty fuch monopoly of fame!

Yet not to birth alone did Homer owe

His wond'rous worth, what Egypt could beftow,

With all the fchools of Greece, and Afia join'd,

Enlarg'd th' immenfe expanfion of his mind.

Nor yet unrivall'd the Meonian ftrain,

The Britin Eagle and the Mantuan Swan

Tower equal heights; but happier, Stratford, thou

With uncontefted laurels deck thy brow!

Thy Bard was thine unfchool'd, and from thee brought More than all Egypt, Greece, or Afia taught;

Not Homer's felf fuch peerlefs honours won,

The Greek has rivals, but thy Shakefpeare none !

In the later editions of Dodfley' Mircellany, the word fwan, in the fourth couplet, 
couplet, is moft abfurdly changed to fwain, becaufe it chimed more completely to the foregoing rhyme, Arain, at the expenfe of every thing like fenfe and accuracy in the appofite terms; at the expenfe of making a bird and a man fly equal heights ere balloons were dreamed of. Mr. Seward was often heard to laugh at this inftance of editorial prefumption and ftupidity*.

Another of the Lichfield literati, overlooked by the arrogant Johnfon, was the Reverend Arch-Deacon Vyfe, the amiable the excellent father of the prefent ingenious Dr. Vyfe of Lambeth, and his gallant brother General Vyfe. Mr. Vyfe was not only a man of learning, but of Prioric talents in the metrical impromptu. Gentle reader, behold an inftance! and if thou hateft not rhyme, as does many an ungentle reader, "worfe than toad or afp," thou wilt not think it intrufive.

* This gentleman was father of the writer of thefe memoirs.

$$
\text { F } 4 \quad \mathrm{Mrs}_{8}
$$


Mrs. Vyfe, herfelf a beautiful woman, had a fair friend whofe name was Char lotte Lynes. At a convivial meeting of Lichfield gentlemen, moft of whom could make agreeable verfes, it was propofed that every perfon in company hould give a ballad or epigram on the lady whofe health he drank. Mr. Vyfe toafted Mifs Lynes, and, taking out his pencil, wrote the following ftanzas extempore.

Shall Pope fing his flames

With quality dames,

And ducheffes toaft when he dines;

Shall Swift verfes compofe

On the Girl at the Rofe,

While unfung is my fair Charlotte Lynes?

O ! were Phoebus my friend,

Or would Bacchus but lend

The fpirit that flows from his vines,

The lafs of the mill,

Molly Mogg, and Lepell,

Should be dowdies to fair Charlotte Lynes.

Any porter may ferve,

- For a copy, to carve 
An Alcides, with mufcular chines;

But a Venus to draw,

Bright as fun ever faw,

Let him copy my fair Charlotte Lynes..

In the midft of gay fights,

And foreign delights,

For his country the banifh'd man pines;

Thus, from her when away,

Though my glances may ftray,

Yet my heart is with fair Charlotte Lynes.

It is Atropus' fport,

With her theers to cut thort

The thread, which dame Lachefis twines

But forbear, you curft jade,

Or cut mine, not the thread

That was fpun for my fair Charlotte Lynes!

For quadrille when the fair

Cards and counters prepare

They caft out the tens, eights, and nines,

And in love 'tis my fear

The like fate I thall thare,

Difcarded by fair Charlotte Lynes.

With hearts full of rapture

Our good dean and chapter

Count 
Count over, and finger their fines;

But-I'd give their eftate,

Were it ten times as great,

For one kifs of my fair Charlotte Lynes.

The young pair, for a crown,

On the book laid him down,

The facrift obfequiounly joins,

Were I bilhop I fwear

Id refign him my chair,

To unite me with fair Charlotte Lynes.

For my firft night I'd go

To thofe regions of fnow,

Where the fun, for fix months, never fhines,

And $O$ ! there fhould complain

$\mathrm{He}$ too foon came again

To difturb me with fair Charlotte Lynes !

Thefe verfes were much read, admired, and copied. Mr. Vyfe thought his fair Charlotte growing too vain in confequence, and once, when the was complimented on the fubject in a large company, he faid fmilingly, 
"Charlotte the power of fong can tell,

"For 'twas the ballad made the belle."

The late Reverend William Robinfon was alfo a choice fpirit amongt thofe Lichfieldians, whofe talents illuminated the little city at that period. Too indolent for authorifm, he was, by wit and learning, fully empowered to have fhone in that fphere. More of him hereafter.

Thefe were the men whofe intellectual exiftence paffed unnoticed by Dr. Johnfon in his depreciating eftimate of Lichfield talents. But Johnfon liked only worfhippers. Arch-deacon Vyfe, Mr. Seward, and Mr. Robinfon, paid all the refpect and attention to Dr. Johnfon, on thefe his vifits to their town, due to his great abilities, his high reputation, and to whatever was eftimable in his mixed character; but they were not in the herd that "paged his heels," and funk, in fervile filence, under the force of his dogmas, when their hearts 
and their judgments bore contrary teftimony.

Certainly, however, it was an arduous hazard to the feelings of the company to oppofe, in the flighteft degree, Dr. Johnfon's opinions. His ftentor lungs; that combination of wit, humour, and eloquence, which "could make the worfe appear the better reafon:" that farcaftic contempt of his antagonift, never fuppreffed or even foftened by the due reftraints of goodbreeding, were fufficient to clofe the lips, in his prefence, of men, who could have met him in fair argument, on any ground, literary or political, moral or characteriftic.

Where Dr. Johnfon was, Dr. Darwin had no chance of being heard, though at leaft his equal in genius, his fuperior in fcience; nor indeed, from his impeded utterance, in the company of any overbearing declaimer; and he was too intellectually great to be an humble liftener to Johnfon, therefore he fhunned him, on having experienced 
perienced what manner of man he was. The furly dictator felt the mortification, and revenged it, by affecting to avow his difdain of powers too diftinguifhed to be an object of genuine fcorn.

Dr. Darwin, in his turn, was not much more juft to Dr. Johnfon's genius. $\mathrm{He}$ uniformly fpoke of him in terms, which, had they been deferved, would have juftified Churchill's " immane Pompofo," as an appellation of fcorn; fince, if his perfon was huge, and his manners pompous and violent, fo were his talents vaft and powerful, in a degree from which only prejudice and refentment could withhold refpect.

Though Dr. Darwin's hefitation in fpeaking precluded his flow of colloquial eloquence, it did not impede; or at all leffen, the force of that concifer quality, wit. Of fatiric wit he poffeffed a very peculiar fpecies. It was neither the dead-doing broadfide of Dr. Johnfon's fatire, nor the aurora borealis of Gray, whofe arch, yet coy and quiet faftidi- 
faftidiournefs of tafte and feeling, as recorded by Mafon, glanced bright and cold through his converfation, while it feemed difficult to define its nature; and while its effects were rather perceived than felt, exciting furprife more than mirth, and never awakening the pained fenfe of being the object of its ridicule. That unique in humorous verfe, the Long Story, is a complete and beautiful fpecimen of Gray's fingular vein.

Darwinian wit is not more eafy to be defined; inftances will beft convey an idea of its character to thofe who never converfed with its poffeffor. To give fuch as are recollected at this moment, it will be neceffary to recall Mr. Robinfon, already mentioned as a choice fpirit of Lichfield. His perpetual ftream of frolic raillery was of a fpecies fo fingular, as to have exclufively obtained, wherever he was known, the title of rector, "The Rector," as if there were no other. The odd excurfions 
of his fancy were enriched by an exhaufters ftore of claffic, hiftoric, and theological learning, grotefquely applied to the paffing fubjects of converfation, and that with unrivalled eafe and happinefs. It is to be regretted that no records remain of talents fo uncommon, except in the fading traces of contemporary recollection, which time and mortality obliterate fo foon.-Frequently, during his youth and middle life, in the farhionable circles of Bath, London, and the fummer public places, the whimfical fallies of the Rector's fportive imagination, which were never coarfe or low, common place or ill-natured, had confiderable publicity and eclat. They were like the lambent lightning of a calm fummer evening, brilliant, but not dangerous. The fweetnefs of his temper was the fecurity of every man's felf-love; and, while his humorous gayety " fet the table " in a roar," the company laughed at their eafe. 
But then good-nature was the only curb his wit could endure. Without the lightert taint of infidelity, Robinfon could not refift the temptation of lancing it even at the moft ferious objects and themes.

One evening, when he and Dr. Darwin were in company together, the Rector had, as ufual, thrown the bridle upon the neck of his fancy, and it was fcampering over the church-yard, and into the chancel, when the Doctor exclaimed - "Excellent! "Mr. Robinfon is not only a clever fellow, "but a $d-d$ clever fellow."

Soon after the fubject of common fwearing was introduced, Mr. R. made a mock eulogium upon its power to animate dullnefs, and to feafon wit.-Dr. Darwin obferved, "Chrift fays, Swear not at all. "St. Paul. tells us we may fwear occa"fronally. Mr. Robinfon advifes us to " fwear inceffantly: Let us compromife "between thefe counfellors, and fwear " by non-en-ti-ties. I will fwear by my 
"im-pu-dence, and Mr. Robinfon by his "6 mo-deft-y."

That gentleman, whofe wit, where it met no equal refiftance, kept an untired and fparkling courfe, could feldom recover its track when the jeft and the laugh were with his adverfary. So often was it thus when Dr. Darwin and he met, that Mr. R. rather fhunned than fought the rencounter. It was curious, that he, who met indulgence from his clerical and pious brethren for thofe frolic emanations, wont to play upon the themes his heart revered, fhould fo often find himfelf reproved, -with cutting raillery, for the practice, by one not famous for holding religious fubjects in veneration.

Dr. Darwin was converfing with a brother Botanift, concerning the plant Kalmia, then a juft imported ftranger in our greenhoufes and gardens. A lady; who was prefent, concluding he had feen it, which in fact he had not, anked the Doctor what 
were the colours of the plant. He replied, " Madam, the Kalmia has precifely the colours of a feraph's wing." So fancifully did he exprefs his want of confcioufnefs refpecting the appearance of a flower whofe name and rarenefs were all he knew of the matter.

Dr. Darwin had a large company at tea. His fervánt announced a ftranger lady and gentleman. The female was a confpicuous figure, ruddy, corpulent, and tall. She held by the arm a little, meek-looking, pale, effeminate man, who, from his clofe adherence to the fide of the lady, feemed to confider himfelf as under her protection.

" Dr. Darwin, I feek you not as a phy"fician, but as a Belle Efprit. I make "this hufband of mine," and the looked down with a fideglance upon the animal: "treat me every fummer with a tour " through one of the Britifh counties, " to explore whatever it contains worth " the attention of ingenious people. On 
8s arriving at the feveral inns in our route, is I always fearch out the man of the "vicinity moft diftinguifhed for his genius " and tafte, and introduce myfelf; that he " may direct, as the objects of our exami" nation, whatever is curious in nature, " art, or fcience. Lichfield will be our " headquarters during feveral days. Come, " Doctor, whither muft we go, what muft "we invertigate to-morrow, and the next "day, and the next? here are my tablets "and pencil."

"You arrive, madam, at a fortunate " juncture. To-morrow you will have an "opportunity of furveying an annual ex" hibition perfectly worth your attention. "To-morrow, madam, you will go to "Tutbury bull-running."

The fatiric laugh with which he ftammered out the laft word, more keenly pointed this $n y$, yet broad rebuke to the vanity and arrogance of her fpeech. She 
had been up amongft the boughs, and little expected they would break under her fo fuddenly, and with fo little mercy. Her large features fwelled, and her eyes flanhed with anger-" I was recommended "to a man of genius, and I find him in"folent and ill-bred."-Then, gathering up her meek and alarmed hufband, whom the had loofed when the firft fpoke, under the fhadow of her broad arm and fhoulder, the ftrutted out of the room.

After the departure of this curious couple, his guefts told their hoft he had been very unmerciful. I chofe, replied he, to avenge the caufe of the little man, whofe nothingnefs was fo oftentatioufly difplayed by his lady-wife. Her vanity has had a fmart emetic. If it abates the fymptoms, The will have reafon to thank her phyfician who adminiftered without hope of a fee. 


\section{H A P TE R - III.}

AвоUт the year I $77 \mathrm{I}$, commenced that great work, the Zoonomia, firft publifhed in 1794 ; the gathered wifdom of threeand-twenty years. Ingenious, beyond all precedent, in its conjectures; and embracing, with giant-grafp, almoft every branch of philofophic fcience; difcovering their bearings upon each other, and thofe fubtle, and, till then, concealed links by which they are united; and with their feparate, conjunctive and collective influence upon human organization; their fometimes probable, and at others demonftrative, power, under judicious application, of reftoring that regularity to the mechanifm of animal life, 
which is comprehended under the term health.

It cannot be denied that in the purfuit of a new and favorite fyftem, Dr. Darwin has, in fome inftances, imperiounly rejected the adverfe facts which oppofed his theory. His chapter on Inftinct, highly ingenious as it is, affords proof of his hypothetical devotion. He there denies, at leaft by ftrong implication, the exiftence of that faculty fo termed, and which God has given to his inferior family, in lieu of the rational. But this wonderfully ingenious philofopher feeks in vain to melt down in his fyftem of imitation amongft brutes, the eternal boundaries which feparate inftinct and reafon.

God, who has exempted the orders of brutal life from refponfibility for their actions in this terreftrial fphere, gave them inftinct, incapable of error, but alfo, beyond a certain very limited degree, incapa- 
ble of improvement; incapable of all that are termed the artificial paffions.

God, who made man accountable, and earthly life his ftate of trial, gave him the nobler faculty of reafon, liable to err, but, in countlefs degrees, more connected with volition; and, according to its different degrees of native ftrength, almort interminably capable of improvement.

Inftinct cannot be that lower degree of reafon which empowers the animal to $o b-$ ferve, and, by will and choice, to imitate the actions, and acquire the arts of his fpecies; fince, were it fo, imitation would not be confined to his own particular genus, but extend to the actions, the cuftoms, and the arts of other animals; as men obferve, and emulate, the actions, cuftoms, and arts of the natives of other countries. Thus, improvement would have advanced amongft brutes, in proportion as it has advanced in mankind. That it has not ad-

$$
\text { G } 4
$$
vanced 
vanced in brutal life, through countlefs generations, we have the teftimony of all records to afcertain. Therefore is it, that the infinctive faculty muft be a totally different power to the rational; in as much as it has a perfection unknown to reafon, and as it has an incapacity of progreffion which counteracts that limited perfection, and renders it a thoufand fold inferior to the expanding, afpiring, and ftrengthening power of human intelligence. Between the feparate nature of thofe faculties, infurmountable and everlafting are the barriers. Philofophy cannot throw them down; but in the attempt, as in many another,

"Vaulting AmBitron doth o'erleap itfelf,

" And falls where it would mount."

If the Creator had indeed given to brutal life that degree of reafon, which Dr. Darwin allots to it, when he afferts, 
that its various orders act from imitation, which muft be voluntary, rather than from impulfe, which is refyflefs, the refulting mirchief of diforder and confufion amongft thofe claffes had outweighed the aggregate good of improvement. It is reafonlefs, will-lefs inftinct, limited but undeviating, which alone could have preferved, as they were in the beginning, are now, and evei thall be, the numberlefs divifions and fubdivifions of all merely animal life. As attraction is the planetary curb of the folar fyftem, confining all orbs to their proper fpheres, fo is inftinct the reftraint, by which brutes are withheld from incroaching upon the allotted ranges and privileges of their fellow-brutes ; from lofing their diftinct natures in imitation, blending and endlefs. If imitation were the fource of brutal acquirements, whence the undeviating famenes of thofe acquirements? whence their never cxtended limit?

Wherefore, 
Wherefore, fince the ear of the feathered warbler is open to the immenfe variety of ftrains, poured from the throat of birds' of other plume, whence its invariable choice of the family fong? And, when the female fees fuch numbers of different nefts building around her for the reception of the callow brood, whence her inflexible attachment to the family neft?

Dr. Darwin read his chapter on Inftinct to a lady, who was in the habit of breeding canary-birds. She obferved that the pair, which he then faw building their neft in her cage, were a male and female, who had been hatched, and reared in that very cage, and were not in exiftence when the moffy cradle was fabricated, in which they firft faw light. She afked him how, upon his principle of imitation, he could account for the neft he then faw building, being conftructed, even to the precife difpofal of every hair and fhred of wool, upon 
the model of that, in which the pair were born, and on which every other canarybird's neft is conftructed, where the proper materials are furnifhed. That of the pyefinch, added the, is of much compacter form, warmer, and more comfortable. Pull one of them to pieces for its materials; place another before thefe canary-birds, as a pattern, and fee if they will make the flighteft effort to imitate their model! No, the refult of their labors will, upon inItinctive, hereditary impulfe, be exactly the flovenly little manfion of their race; the fame with that which their parents built before themfelves were hatched. The Doctor could not do away the force of that fingle fact, with which his fyftem was incompatible; yet he maintained that fyftem with philofophic fturdinefs, though experience brought confutation from thoufand fources.

Mr. Fellowes, the eminent champion in our 
our day, of true and perfect Chriftianity, againft the gloomy mifreprefentations of the Calvinifts, has not lefs truely than ingenioufly obferved, that "Dr. Darwin's " underftanding had fome of the properties " of the microfcope; that he looked with "fingularly curious and prying eyes, into " the economy of plants and the habits " of animals, and laid open the labyrinth " of nature in fome of her moft elabo"rate proceffes and moft fubtle combina"tions; that he was acquainted with " more links in the chain of fecond caufes "than had probably been known to any "s individual, who went before him; but "s that he dwelt fo much, and fo exclufively " on fecond caufes, that he too generally "feems to have forgotten that there is a " firft."

Certainly Dr. Darwin's diftinguifhed power of difclofing the arcana of nature, enabled him to explore, and detect, the fallacy 
fallacy of many received and long-eftablifhed opinions ; but the proud confciournefs that his fcientific wand fo often porfeffed the power attributed by Milton to Ithuriel's fpear, betrayed him, at times, into fyftematic error. Convinced, by deep thought and philofophic experience, that mankind received fo many prejudices for truths, he looked too jealoufly at all its mort revered and facred axioms. Beneath the force of that jealoufy he denied the power of inftinct, and folved it into imitation. To have admitted, on the teftimony of all impartial obfervation, all fair experiment, the unblending natures of inftinct and reafon, muft have involved that refponfibility of man to his Creator for hisactions in this his ftate of trial, which Dr. Darwin confidered as a gloomy unfounded fuperftition. Unqueftionably, if reafon, like inftinct, were incapable of warp from the power of volition, man 
could have no vice which might juftly render him amenable to punifhment in a future ftate; neither could he have any virtue for whofe cultivation he might hope eternal reward. But, fince his rational faculty is choice, not impulfe, capable, at will, of refinement or degradation; whether it thall be his pole-ftar to virtue and piety, or his ignis-fatuus to vice and irreligion, it inevitably follows that man is accountable to God for his conduct; that there is a future and retributory ftate.

If this brilliant and dazzling philofopher had not clofed the lynx's eye of his underftanding on that clear emanation from the fource of intellectual as well as of planetary light, he had indeed been great and illuminated above the fons of men. Then had he difdained to have mingled that art in his wifdom, which was fometimes found in his common-life actions, and of which he not unfrequently boafted.

That 
That noble fimplicity which difdains the varnifh of difingenuous defign in principle and in conduct, in converfation and in writing, was the defideratum of Dr. Darwin's ftrong and comprehenfive mind. It's abfence rendered his fyftems, which were fo often luminous, at times impenetrably dark by paradox. It's abfence rendered his poetic tafte fomewhat meretricious from his rage for ornament ; chilled his heart againft the ardor of devotion, and chained his mighty powers within the limits of fecond caufes, though formed to foar to INFINITE.

If, however, the doctrines of the Zoonomia are not always infallible, it is 2 work which muft fpread the fame of it's author over lands and feas, to whatever clime the fun of fcience has irradiated and warmed. The Zoonomia is an exhauftlefs repofitory of interefting facts, of curious experiments in natural productions, and in 
medical effects; a vaft and complicated fcheme of difquifition, incalculably important to the health and comforts of mankind, fo far as they relate to objects merely terreftrial; throwing novel, ufeful, and beautiful light on the fecrets of phyfrology, botanical, chemical, and aerological.

The world may confider the publication of the Zoonomia as a new era of pathologic fcience; the fource of important advance in the power of difclofing, abating, and expelling difeafe. Every young profeffor of medicine, if God has given him comprehenfion, affiduity, and energy, hould devote his nights and days to ftudying this great work. It will teach him more than the pages of Galen and Hippocrates; than fchools and univerfities know to impart. Thofe inftructions which, through the channel of it's pages, flow to the world, enabled Dr. Robert Darwin of Shrewfoury 
tó attain inftant eminence as a phyfician in that county, at his firft outfetting, and in the bloom of fcarcely ripened youth; to continue a courfe of practice, which has been the bleffing of Shrophire; it's fphere expanding with his growing fame. That fon, who joins to a large portion of his father's fcience and fkill, all the ingenuous kindnefs of his mother's heart. That fon, whofe rifing abilities and their early eclat, recompenfed to Dr. Darwin a fevere deprivation in the death of his eldeft and darling fon, Charles, of whom this memoir has already fpoken. He was fnatched from the world in the prime of his youth, and with the higheft character at the univerfity of Edinburgh, by a putrid fever, fuppofed to have been caught from diffecting, with a flightly wounded finger, a corpfe in a ftate of dangeroufly advanced putrefaction. When fociety became deprived of his luxuriantly bloffom- 


\section{$9^{8}$}

ing talents, Mr. Charles Darwin had recently received an honorary medal from the Society of Arts and Sciences, for having difcovered a criterion by which pus may be diftinguifhed from mucus.

A few years before Dr. Darwin left Lichfield as a refidence he commenced a botanical focicty in that city. It confifted of himfelf, Sir Brooke Boothby, then Mr. Boothby, and a Proctor in the Cathedral jurifdiction, whofe name was Jackfon. Sprung from the loweft poffible origin, and wholly uneducated, that man had, by the force of literary ambition and unwearied induftry, obtained admittance into the courts of the fpiritual law, a profitable fhare of their emoluments, and had made a tolerable proficience in the Latin and French languages. His life, which clofed at fixty, was probably fhortened by late acquired habits of ebriety. He pafled through it's courfe a would-be philofopher,

a turgid 
a turgid and folemn coxcomb, whofe morals were not the beft, and who was vain of lancing his pointlefs fneers at Revealed Religion.

Jackfon admired Sir Brooke Boothby, and worlhipped and aped Dr. Darwin. $\mathrm{He}$ became a ufeful drudge to each in their joint work, the tranflation of the Linnean fyftem of vegetation into Englifh from the Latin. His illuftrious coadjutors exacted of him fidelity to the fenfe of their author, and they corrected Jackfon's inelegant Englifh, weeding it of it's pompous coarfeners.

The Doctor was probably difappointed that no recruits flocked to his botanical ftandard at Lichfield. The young men of the genteel claffes in that city devoted themfelves to profeffions with which natural hiftory had no infeparable connexion. However ufeful, entertaining, and creditable might be it's ftudies, they felt little defire to deck the board of fer- 
fion, the pulpit, or the enfigns of war, with the Linnean wreaths and the chemical cryftalines. Thus the original triumvirate received no augmentation, yet the title was maintained. Various obferwations, figned Lichfield Botanical Society, were fent to the periodical publications, and it was amufing to hear fcientific travellers, on their tranfit over Lichfield, inquiring after the ftate of the botanical fociety there.

About the year 1779, at the houfe of his friend, Mr. Sneyd of Belmont, whofe feat in the wild and hilly part of Staffordthire Moorlands is eminent for its boldly romantic features, Dr. Darwin wrote an addrefs to its owner, from the Naiad of that fcene. Her rivulet originally took its courfe along the deep bottom of cradling woods, luxuriantly clothing the fteeplyfloping mountains, which a rough glen, and this it's brook, divided. 
Mr. Sneyd caufed the rough and tangled glen to be cleared and hollowed into one entire bafin, which the brook immediately filled with the pureft and moft tranfparent water, Only a very narrow, marginal path is left on each fide, between the water and thofe high woody mountains which thut the liquid fcene from every other earthly object. This lake covers more than five acres, yet is not more than feventy yards acrofs at the broadeft part. The length is, therefore, confiderable. It gradually narrows on it's flow, till fuddenly, and with loud noife, it is precipitated down a craggy, darkling, and nearly perpendicular fall of forty feet. The ftream then takes its. natural channel, lofing itfelf in the fombre and pathlefs woods which ftretch far onward.

While we walk on the brink of this liquid concave; while we liften to the roar, with which the tumbling torrent paffes

$$
\text { H } 3
$$

away; 
away; while we look up, on each fide, to the umbrageous eminences, which leave us only themfelves, the water, and the fky, we are impreffed with a fenfe of folemn feclufion, and might fancy ourfelves in the folitudes of Tinian or Juan-Fernandes. The trees and fhrubs which, from fuch great elevation, impend over the flood, give it their own green tint without leffening its tranfparency. Glaffy fmooth, this lake has not a wave till within a few yards of its precipitance. But it is time to introduce Dr. Darwin's verfes, already mentioned. They were written before the exiftence of the Lake, and while the brook, which formed it, had the filence imputed to it by the poet.

Addrefs of a Water Nymph, at Belmont, to the Owner of that place.

O1 Friend to Peace and Virtue, ever flows

For thee my filent and unfullied ftream, 
Pure and untainted as thy blamelers life!

Let no gay converfe lead thy fteps aftray

To mix my chafte wave with immodeft wine,

Nor with the poifonous cup, which Chemia's hand

Deals, fell enchantrefs, to the fons of folly!

So thall young Health thy daily walks attend,

Weave for thy hoary brow the vernal flower

Of chcerfulnefs, and with his nervous arm

Arreft th' inexorable fcythe of Time.

The exhortation was not difobeyed; the benediction was not fruitlefs. Mr. Sneyd ftill lives to exhilarate the fpirits of his friends, and to be the bleffing of his neighbourhood. The duties of a public magiftrate, exerted with energy, and tempered with kindnefs; the hofpitality of his focial manfion; his purfuit of natural hiftory, and tafte for the arts, are unleffened by time, and no corporal infirmity allays their enjoyment. After a lapfe of feventy years he paffes feveral hours every day, in all feafons when the weather is dry, in the open air, forming for his fcenes new plans 
of cultivation and ornament. Look at Mr. Sneyd, ye young men of fortune, and reflect upon the robuft and happy confequence of youthful fobriety, of religion, morality, and a cultivated mind!

" The age of Juclu is as a lufty winter,

" Frofty, but kindly.

In the fpring of the year 1778 the children of Colonel and Mrs. Pole of Radburn, in Derbythire, had been injured by a dangerous quantity of the cicuta, injudicioufly adminiftered to them in the hoopingcough, by a phyfician of the neighbourhood. Mrs. Pole brought them to the houfe of Dr. Darwin, in Lichfield, remaining with them there a few weeks, till, by his art, the poifon was expelled from their conftitutions, and their health re. ftored.

Mrs. Pole was then in the full bloom of her youth and beauty. Agreeable features; 
tures; the glow of health; a fafcinating fmile; a fine form, tall and graceful; playful fprightlinefs of manners; a benevolent heart, and maternal affection, in all its unwearied cares and touching tendernefs, contributed to infpire Dr. Darwin's admiration, and to fecure his efteem. Soon after the left Lichfield, with her renovated little ones, their reftorer fent to his friend, Mr. Bolton of Birmingham, the following directions for making a tea-vafe, defigned as a prefent from the Doctor to Mrs. Pole.

Friend Bolton, take thefe ingots fine From rich Potofi's fparkling mine; With your nice art a tea-vafe mould, Your art, more valu'd than the gold. With orient pearl, in letters white, Around it, "To the Fairent," write; And, where proud Radburn's turrets rife, To bright Eliza fend the prize,

I'll have no bending ferpents kirs The foaming ware, and feem to hifs; 
No fprawling dragons gape with ire, Aud fnort out fteam, and vomit fire; No Naiads weep; no fphinxes ftre; No tail hung dolphins fwim in air. Let leaves of myrtle round the rim, With rofe-buds twifting, thade the brim; Each fide let woodbine ftalks defcend, And form the branches as they bend; While on the foot a Cupid ftands And twines the wreath with both his hands,

Perch'd on the rifing lid above,

O place a lovelorn, turtle dove,

With hanging wing, and ruffled plume,

With gafping beak, and eye of gloom.

Laft, let the fwelling boffes fhine With filver, white, and burniflid fine, Bright as the fount, whofe banks befide Narciffus gaz'd, and lov'd, and died.

Vare, when Éliza deigns to pour, With fnowy hand, thy boiling fhower; And fweetly talks, and fmiles, and fips The fragrant fteam, with ruby lips, More charms thy polifh'd orb thall thew Than Titian's glowing pencil drew;

- More than "his chifel foft unfurl'd, Whofe heav'n-wrought ftatue charms the world. 
Soon after the compofition of thefe gallant verfes to Mrs. Pole, circumitances arofe which gave rife to the following ode, not lefs beautiful, though much lefs gay.

Fly, gentle fteeds ! - o'er yon unfriendly towers Malignant ftars, with baleful influence reign; Cold Beauty's frown infects the cheerlefs hours, And Avarice dwells in Love's polluted fane!

Dim, diffant towers! whofe ample roof protects All that my beating bofom holds fo dear, Far hining lake $\downarrow$ whofe filver wave reflects Of Nature's faireft forms, the form moft fair;

Groves, where at noon the neeping Beauty lies; Lawns, where at eve ber graceful footfteps rove; For ye full of have heard my fecret fighs, And caught unfeen, the tear of hopelefs love;

Farewell! a long farewell !-your fhades among.

No more thefe eyes thall drink Eliza's charms;

No more thefe ears the mufic of her tongue! -

O! doom'd for ever to another's arms! 
Fly, gentle fteeds ! - my bleeding heart convey

Where brighter Icenes and milder planets thine;

Where Joy's white pinion glitters in the ray,

And Love fits fmiling on his cryftal fhrine !

About the fummer 1778 the Countefs of Northefk refted at one of the inns in Lichfield, on her way to Scotland by the fhorteft poffible ftages. She had been a year in England, for the benefit of her health, wafting rapidly by hemorrhage. Ineffectually had the moft eminent phyficians of London and Bath endeavoured to check the progrefs of her difeafe. Her youngeft daughter, Lady Marianne Carnegie, then an amiable girl of thirteen ${ }_{2}$ now alas no more, and their friend, Mrs. Scott, were the companions of Lady Northefk's journey. Her ladyfhip told the miftrefs of the inn that the was going home to die, the phyficians having confeffed that art could do no more 
in her cafe. The perfon replied, "I wifh, "Madam, that you would fend for our "Doctor, he is fo famous." Lady Northefk confented.

When Dr. Darwin came, he obferved. that he could do little on tranfient obfervation, where the difeafe was fo obftinate, and of fuch long continuance; preffed her to remove with her daughter and friend to his houfe, and that they would remain his guefts during a fortnight. The invitation was accepted. He requefted the author of thefe memoirs frequently to vifit his new patient, contribute to amufe her, and abate the inevitable injury of perpetual felf-attention.

Mifs Seward felt herfelf extremely interefted in this lady, and anxious to fee thofe fufferings relieved which were fo patiently fuftained. Lady Northerk lay on a couch, through the day, in Dr. Darwin's parlour, drawing with difficulty that breath, which 
feemed often on the point of final evaporas tion. She was thin, even to tranfparency; her cheeks fuffufed at times with a flunh, beautiful, though hectic. Her eyes remarkably lucid and full of intelligence. If the languor of difeafe frequently overhadowed them, they were always relumined by every obfervation to which the liftened, on lettered excellence, on the powers of fcience, or the ingenuity of art. Her language, in the high Scotch accent, had every happinefs of perfpicuity, and always expreffed rectitude of heart and fufceptibility of tafte.

Whenever her great and friendly phyfician perceived his patient's attention engaged by the converfation of the reft of the circle, he fat confidering her in meditative filence, with looks that expreffed,"You thall not die thus prematurely, if " my efforts can prevent it."

Ore evening, after a long and intenfé 52037 reveries 
reverie, he faid,-"Lady Northefk, an art "was practifed in former years, which " the medical world has very long difufed; " that of injecting blood into the veins by " a fyringe, and thus repairing the wafte " of difeafes like yours. Human blood, "and that of calves and heep, were "ufed promifcuouny. Superftition at" tached impiety to the practice. It was "put a ftop to in England by a bull of " excommunication from fome of our "Popifh Princes, againft the practitioners " of fanguinary injection. - That it had " been practifed with fuccefs, we may, "from this interdiction, fairly conclude; " elfe reftraint upon its continuance muft " have been fuperfluous. We have a very " ingenious watch-maker here, whom I " think I could inftruct to form a proper "inftrument for the purpofe, if you chofe "to fubmit to the experiment." - She replied cheerfully, "that the had not "the 
"the leaft objection, if he thought it "eligible."

Mifs Seward then faid- "If the trial " Thould be determined upon, perhaps "Lady Northerk would prefer a fupply "from an healthy human fubject, rather "than from an animal. My health is "perfect, neither am I confcious of any " lurking diseafe, hereditary or accidental. "I have no dread of the lancet, and will " gladly fpare, from time to time, fuch a " portion from my veins to Lady Northefk, "as Dr. Darwin Shall think proper to " inject."

He feemed much pleafed with the propofal, and his amiable patient expreffed gratitude far above the juft claim of the circumftance. Dr. Darwin faid he would confult his pillow upon it.

The next day, when Mifs S. called upon Lady N. the Doctor took her previoufly into his ftudy, telling her, that he 
had refigned all thoughts of trying the experiment upon Lady Northefk; that it had occurred to him as a laft refource, to fave an excellent woman, whofe diforder, he feared, was beyond the reach of medicine ; "but," added he, "the con"ftruction of a proper machine is fo nice " an affair, the leaft failure in its power " of acting fo hazardous, the chance at "laft from the experiment, fo precarious, " that I do not choofe to ftake my reputa"tion upon the rifque. If the clie, the " world will fay I killed Lady Northefk, "though the London and Bath phyficians " have pronounced her cafe hopelefs, and "fent her home to expire. They have. "given her a great deal too much medicine. "I thall give her very little. Their fyftem " of nutritious food, their gravy jellies, and "ftrong wines, I have already changed for " milk, vegetables, and fruit. No wines ever; " no meat, na ftrong broth, at prefent. If 
"this alteration of diet prove unavailing, "her family and friends muft lofe her."

It was not unavailing; the gathered ftrength under the change from day to day. The difeafe abated, and in three weeks time the purfued her journey to Scotland, a convalefcent, full of hope for herfelf; of grateful veneration towards her phyfician, whofe refcuing fkill had faved her from the grave; and full, alfo, of overrating thankfulnefs to Mifs S. for the offer the had made. With her, Lady Northefk regularly correfponded from that time till her fudden and deplorable death. . All Lady N.'s letters fpoke of completely recovered health and ftrength. She fent Mifs Seward a prefent of fome beautiful Scotch pebbles for a necklace, picked up by her own hands, in her Lord's park, and polifhed at Edinburgh .

Lady Northenk might have lived to old. age, the bleffing of her family and friends. 
Alas! the time had paffed by in which Mifs Seward was accuftomed to expect a letter from her friend!

Inquiry taught her that Lady Northerk had perifhed by the dreadfully-frequent accident of having fet fire to her clothes. Lady Marianne Carnegie wrote to Mifs S. the year after, and continued to honor her with feveral letters while her Ladyfhip lived with her father at Ethic Houfe, on the ocean's edge. It was there that fhe dedicated many of her youthful years to the pious endeavour of mitigating Lord Northerk's deep anguiph for the lofs of his Lady, which had induced him inflexibly to renounce all fociety, except with his own family. That might be faid of Ethic Houfe which Dr. Johnfon faid of the Ifle of Raafay, in the Hebrides. "Without " were the dark rocks, the roaring winds, " and tumultuous deep;" but, alas for Lady Marianne! it could not alfo be faid, 
as of Raafay, that "witlin were the "focial comforts, the voice of gaiety, the " dance, and the fong." Yet did the fupport, with uncomplaining patience, in the flower of her youth, this deep folitude; this monotony of natural objects, in which little variety could be found, beyond the change of fmiling and frowning feas, the hufhed and the bellowing waters.

In the autumn of this year Mrs. Pole of Radburn was taken ill; her diforder a violent fever. Dr. Darwin was called in, and perhaps never, fince the death of Mrs. Darwin, prefcribed with fuch deep anxiety: Not being requefted to continue in the houfe through the enfuing night, which he apprehended might prove critical, he paffed the remaining hours till day-dawn beneath a tree oppofite her apartment, watching the paffing and repaffing lights in the chamber. During the period in which a life he fo paffionately valued was: 
in danger, he paraphrafed Petrarch's celebrated fonnet, narrating a dream, whofe prophecy was accomplifhed by the death of Laura. It took place the night on which the vifion arofe amid his number. Dr. Darwin extended the thoughts of that fonnet into the following elegy.

Dread Dream, that, hovering in the midnight air, Clafp'd, with thy duky wing, my aching head, While, to Imagination's ftartled ear,

Toll'd the flow bell, for bright Eliza dead.

Stretch'd on her fable bier, the grave befide, A fnow-white throud her breathlefs bofom bound,

- O'er her wan brow the mimic lace was tied, And Loves, and Virtues, hung their garlànds round.

From thofe cold lips did fofteft accents flow?

Round that pale mouth did fweetert dimples play?

On this dull cheek the rofe of beauty blow, And thore dim eyes diffure celeftial day?

Did this cold hand unalking want relieve, Or wake the lyre to every rapturous found ? How fad, for other's woe, this breaft would heavel How light this heart, for other's tranfport, bound ! 
Beats not the bell again ?-Heav'ns ! do I wake? Why heave my fighs, why gufh my tears anew ?

Unreal forms my trembling doubts miftake, And frantic Sorrow fears the vifion true.

Dream! to Eliza bend thy airy flight, Go, tell my charmer all my tender fears, How Love's fond woes alarm the filent night, And fteep my pillow in unpitied tears.

The fecond verfe of this charming elegy affords an inftance of Dr. Darwin's too exclufive devotion to diftinct picture in poetry; that it fometimes betrayed him into bringing objects fo precifely to the eye, as to lofe in fuch precifion their power of ftriking forcibly upon the heart. The pathos in that fecond verfe is injured by the words, " mimic lace," which allude to the perforated borders of the fhroud. The expreffion is too minute for the folemnity of the fubject. Certainly it cannot be natural for a fhocked and agitated mind to obferve, or to defcribe with fuch petty accurary. Befides 
the allufion is not fufficiently obvious. The reader paufes to confider what the poet means by "mimic lace." Such paufes deaden fenfation, and break the courfe of attention. A friend of the Doctor's pleaded ftrongly that the line might run thus,

"On her wan brow the fradoruy crape was tied;"

but the alteration was rejected. Inattention to the rules of grammar in the firft verfe, was alfo pointed out to him at the fame time. The dream is addreffed,

"Dread dream, that clafped my aching head,"

but nothing is faid to it; and therefore the fenfe is left unfinifhed, while the elegy proceeds to give a picture of the lifelefs beauty. The fame friend fuggefted a change, which would have remedied the defect, thus,

"Dread rus the dream, that, in the midnight air, "Clafp'd, with it's dufky wing, my aching head, "While to, \&rc." 
Hence, nat only the grammatic error would have been done away, but the grating found, produced by the near alliteration of the harn $d r$, in "dread dream," removed, by placing thofe words at a greater diftance from each other.

This alteration was, for the fame reafon, rejected. The Doctor would not fpare the word hovering, which he faid ftrengthened the picture; but furely the image ought not to be elaborately precife, by which a dream is transformed into an animal, with black wings.

Soon after Mrs. Pole's recovery from her dangerous illnefs, Dr. Darwin wrote the following little poem.

ODE TO THE RIVER DERWENT;

Written in a romantic Valley near its source.

Derwent, -what fcenes thy wandering waves behold, As burfting from thine hundred fprings they fray, And down thefe vales, in founding torrents roll'd, Scek to the fhining Eaft their mazy way! 
Here dufky alders, leaning from the cliff,

Dip their long arms; and wave their branches wide;

There, as the loofe rocks thwart my bounding fkiff,

White moonbeams tremble on the foaming tide.

Pafs on, ye waves, where, drefs'd in lavifh prine,

Mid rofeate bowers, the gorgeous Chatfworth beams, Spreads her fmooth lawns along your willowy fide,

And eyes her gilded turrets in your ftreams.

Pafs on, ye waves, where Nature's rudeft child,

Frowning incumbent o'er the darken'd floods,

Rock rear'd on rock, mountain on mauntain pil'd,

Old Matlock fits $s_{2}$ and thakes his creft of woods.

But when fair Derby's ftately towers you view, Where his bright meads your fparkling currents drink;

OI fhould Eliza prefs the morning dew, And bend her graceful footfteps to your brink,

Uncurl your eddies, all your gales confine, And, as your fcaly nations gaze around, Bid your gay nymphs pourtray, with pencil fine, Her radiant form upon your filver ground.

With playful malice, from her kindling cheek Steal the warm blufh, and tinge your paffing ftream; Mock the fweet tranfient dimples, as the fpeaks, And, as the turns her eye, reflect the beam! 
And tell her, Derwent, as you murmur by, How in thefe wilds with hopelefs love I burn, Teach your lone vales and echoing caves to figh, And mix my briny forrows with your urn?

This elegiac ode is rich in poetic beauty. The epithet willowy, in the third ftanza, appeared queftionable, till it was recollected that it is the weeping willow that was meant, with which art has adorned the Derwent in his courfe through the lawns of Chatfworth. The common fpecies of that tree has no fpontaneous growth on the edge of rivers which alternately rufh and flow through their rocky channel in mountainous countries. Common willows border the heavy, fluggifh ftreams of flat and fwampy fituations. Dwarf-alders, nuttrees, and other buhes of more ftinted height, and darker verdure, fringe the banks of the Derwent, the Wie, and the Larkin, on their paffage through the Peak-

fcenery, 
fcenery, and form a more rich and beautiful curtain than the taller, the ftraggling, and pale-hued willow.

Matlock is not juftly called Nature's rudeft child. If his rocks were without clothing, he might properly be fo called. Rude gives an idea of barrennefs, and Matlock is luxuriantly umbraged; much more luxuriantly than Dove-Dale; while every traveller through Derbyfhire muft recollect, how rich and fmiling the Matlock-fcenery, compared to the favage magnificence of Eyam-Dale, commonly, though not properly, called Middleton-Dale.

There, indeed, we fee rocks piled on rocks, unfoliaged and frowning. They form a wall, of vaft height, on either fide the white limeftone bottom of that deep and narrow valley, with the little fparkling rill which fpeeds through it.

In feveral reaches of the curves, made by this Salvatorial Dale, it is from the 
temperature of the air alone that the feafons can be afcertained; fince there are no trees, to mark by their foliage the reign of fylvan beauty; no grafs, to denote it by its lively hue. Nothing but the grey, the barren, and lonely rocks, with, perhaps, a few ftraggling Scotch firs waving on the tops of the cliffs above; and their dufky fprays neither winter ftrips nor fpring enlivens.

This dale is, indeed, "Peak's rudeft " child." Of late years, injury has been done to the towery and fantaftic forms of many of the rocks, from their having been broken in pieces by gunpowder explofion, for the fake of mending the turnpike roads. The mills; for fmelting the lead-ore in this dale, blot the fummer noon, and increafe its fultrinefs by thofe volumes of black fmoke which pour out from their chimnies; but in the night they have a grand effect, from the flare 
of the pointed flames, which ftream amid the fmoke, and appear like fo many fmall rolcanos.

Mr. Longfton, of Eyam, has adorned a part of this fcene by a hanging garden and imitative fort. The fteep, winding paths of the garden are planted with wild - thrubs, natives of the fteril foil, and which root their fibres in the fiffures of the rocks. The effect, in defcending thofe paths from the cliffs above, is very ftriking. They command the ftupendous depths of the vale below and a confiderable portion of its curve.

About the year 1777 , Dr. Darwin purchafed a little, wild, umbrageous valley, a mile from Lichfield, amongft the only rocks which neighbour that city fo nearly. It was irriguous from various fprings, and fwampy from their plenitude. A moffy fountain, of the pureft and coldeft water imaginable, had, near a century back, in- 
duced the inhabitants of Lichfield to build a cold bath in the bofom of the vale. That, till the doctor took it into his poffeffion, was thie only mark of human induftry which could be found in the tangled and fequeftered fcene.

One of its native features had long excited the attention of the curious; a rock, which, in the central depth of the glen; drops perpetually, about three times in a minute. Aquatic plants border its top and branch from its fiffures. No length of fummer drought abates, no rains increafe its humidity, no froft congeals its droppings. The Doctor cultivated this fpot,

"And Paradife was open'd in the wild."

In fome parts he widened the brook into fmall lakes, that mirrored the valley; in others, he taught it to wind between nurubby margins. Not only, with trees of various 
various growth did he adorn the borders of the fountain, the brook, and the lakes, but with various claffes of plants, uniting the Linnean fcience with the charm of landfcape.

For the Naiad of the fountain, he wrote the following infcription.

\section{SPEECH OF A WATER NYMPH.}

If the meek flower of bafhful dye,

Attract not thy incurious eye ;

If the foft, murmuring rill to reft

Encharm not thy tumultuous breaft,

Go, where Ambition lures the vain,

Or Avarice barters peace for gain !

Dr. Darwin reftrained his friend Mifs Seward's fteps to this her always favourite fcene till it had affumed its new beauties from cultivation. He purpofed accompanying her on her firft vifit to his botanic garden, but a medical fummons into the country deprived her of that pleasure. 
pleafure. She took her tablets and pencil, and, feated on a flower-bank, in the midft of that luxuriant retreat, wrote the following lines, while the fun was gilding the glen, and while birds, of every plume, poured their fong from the boughs.

O, come not here, ye Proud, whofe breafts infold Th' infatiate with of glory, or of gold;

O come not ye, whofe branded forcheads wear Th' eternal frown of envy, or of care ;

For you no Dryad decks her fragrant bowers; For you her fparkling urn no Naiad pours; Unmark'd by you light Graces fkim the green, And hovering Cupids aim their thafts unfeen.

But, thos! whofe mind the well-attemper'd ray Of Tafte, and Virtue, lights with purer day; Whofe finer fenfe each foft vibration owns, Mute and unfeeling to difcorded tones; Like the fair flower that fpreads itsilucid form To meet the fun, but huts it to the form; For thee my borders nurfe the glawing wreath, My fountains murmur, and my zephyrs breathe; My painted birds their vivid plumes unfold, And infee armies wave their wings of gold. 
And if with thee fome haplefs maid thould ftray, Difaftrous love companion of her way,

O lead her timid ftep to yonder glade,

Whofe weeping rock incumbent alders thade!

There, as meek Evening wakes the temperate breeze, And moonbeams glimmer through the trembling trees, The rills, that gurgle round, thall footh her ear, The weeping rock thall number tear for tear; And as fad Philomel, alike forlorn, Sings to the night, reclining on her thorn, While, at fweet intervals, each falling note Sighs in the gale, and whifpers round the grot, The fifter-woe fhall calm her aching breaft, And fofteft ilumbers fteal her cares to reft.

Thus fpoke the "Genius as he ftept along, And bade thefe lawns to Peace and Truth belorig; Down the fteep flopes he led, with modert $\mathrm{kkill}_{\text {, }}$ The graffy pathway and the vagrant rill; Stretch'd o'er the marhy vale the willowy mound, Where thines the lake amid the cultur'd ground; Rais'd the young woodland, fmooth' d' the wavy green, And gave to Beauty all the quiet fcene.

O! may no ruder ftep thefe bowers prophane, No midnight waffailers deface the plain;

* By the Genius of the place is meant its firft cultivator, Dr. Darwin. 
And when the tempefts of the wintry day Blow golden Autumn's varied leares away, Winds of the North, reftrain your icy gales, Nor chill the borom of thefe HaLLOWED VALES I*

When Mifs Seward gare this little poem to Dr. Darwin, he feemed pleafed with it, and faid, "I fhall fend it to the "periodical publications; but it ought to "form the cxordium of a great work. "The Linnean Syftem is unexplored poetic "ground, and an happy fubject for the " muife. It affords fine fcope for poetic "landfcape; it fuggefts metamorphofes "of the Ovidian kind, though reverfed. "Ovid made men and women into flowers, "plants, and trees. You hould make

- Thefe verfes, in their original ftate, as infcribed here, will be found in Mr. Shaw's Hiftory of Staffordmire, publimed in 1798, near four years before the death of Dr. Darwin ; fee Article Lichfield, page 347. Their author chofe to affert her claim to them in the Doetor's lifetime, fince they had appeared in the periodical Publications many years before the Botanic Garden paffed the prefs, and had borne her fignature. 
"Howers, plants, and trees, into men and " women. I," continued he, " will write " the notes, which muft be fcientific; and " you thall write the verfe."

Mifs S. obferved, that, befides her want of botanic knowledge, the plan was not ftrictly proper for a female pen; that the felt how eminently it was adapted to the efflorefcence of his own fancy.

$\mathrm{He}$ objected the profeffional danger of coming forward an acknowledged poet. It was pleaded, that on his firft commencing medical profeffor, there might have been no danger; but that, beneath the unbounded confidence his experienced fkill in medicine had obtained from the public, all rifque of injury by reputation flowing in upon him from a new fource was precluded; efpecially fince the fubject of the poetry, and ftill more the notes, would be connected with pathology.

Dr. Darwin took his friend's advice, 
and very foon began his great poetic work; but previoufly, a few weeks after : they were compofed, fent the verfes Mifs S. wrote in his Botanic Garden, to the Gentleman's Magazine, and in her name. From thence they were copied in the Annual Regifter; but, without confulting her, he had fubftituted for the laft fix lines, eight of his own. He afterwards, and again without the knowledge of their author, made them the exordium to the firft part of his poem, publinhed, for certain reafons, fome years after the fecond part had appeared. No acknowledgment was made that thore verfes were the work of another pen. Such acknowledgment ought to have been made, efpecially fince they pafled the prefs in the name of their real author. They are fomewhat altered in the exordium to Dr. Darwin's Poem, and eighteen lines of his own are interwoven with them. 
In September 1780 , a playful corre. fpondence paffed between Dr. Darwin and Mifs Seward, in the name of their refpective cats. The fubject was ludicrous as it was fingular, but the mock-heroic refult pleafed very generally, as the permiffion of taking copies had been folicited and obtained by feveral of their acquaintance. Some literary friends of the writer of thefe pages, remembering the bagatelles with pleafure, perfuaded her to infert them. She is apprehenfive that they may be confidered as below the dignity which a biographic fketch of deceafed Eminence ought perhaps to preferve; yet, as in this whimfically gay effufion, Dr. Darwin appears in a new light of comic wit and Iportive ingenuity, the ventures to comply with their requeft. 
From the Perfian Snow, at Dr. Darwin's, to Mifs Po Felina, at the Palace, Lichfield.

\section{Lichfield Vicarage, Sept. $7,1780$.}

Dear Mifs Puffey,

As I fat, the other day, bafking myfelf in the Dean's Walk, I faw you, in your ftately palace, wafhing your beautiful round face, and elegantly brinded ears, with your velvet paws, and whifking about, with graceful finuofity, your meandering tail. That treacherous hedgehog, Cupid, concealed himfelf behind your tabby beatuties, and darting one of his too well aimed guills, picrced, $O$ crucl imp! my fluttcring heart.

Ever fince that fatal hour have I watched, day and night, in my balcony, hoping that the ftillnefs of the ftarlight evenings 
evenings might induce you to take the air on the leads of the palace. Many ferenades have I fung under your windows; and, when you failed to appear, with the found of my voice made the vicarage re-echo through all its winding lanes and dirty alleys. All heard me but my cruel Fair-one; the, wrapped in fur, fat purring with contented infenfibility, or flept with untroubled dreams.

Though I cannot boaft thofe delicate varicties of melody with which you fometimes ravin the ear of night, and 1tay the liftening ftars; though you fleep hourly on the lap of the favourite of the mufes, and are patted by thofe fingers which hold the pen of fcience; and every day, with her permiffion, dip your white whifkers in delicious cream; yet am I not deftitute of all advantages of birth, education, and beauty. Derived from Perfian kings, my fnowy fur yet retains

$$
\text { K } 4
$$


the whitenefs and fplendor of their ermine.

This morning, as I fat upon the Doctor's tea-table, and faw my reflected features in the nop-bafin, my long white whikkers, ivory teeth, and topaz eyes, I felt an agreeable prefentiment of my fuit; and certainly the flop-bafin did not flatter me, which fhews the azure flowers upon its borders lefs beauteous than they are.

You know not, dear Mifs Puffey Po, the value of the addrefs you neglect. New milk have $\mathrm{I}$, in flowing abundance, and mice pent up in twenty garrets, for your food and amufement.

Permit me, this afternoon, to lay at your divine feet the head of an enormous Norway Rat, which has even now ftained my paws with its gore. If you will do me the honor to fing the following fong, which I have taken the liberty to write, as expreffing the fentiments I wifh you to enter- 
entertain, I will bring a band of catgut, and catcall, to accompany you in chorus.

$$
\text { Air :-fpirituofi. }
$$

Cats I fcorn, who, lleek and fat, Shiver at a Norway rat;

Rough and hardy, bold and free, Be the cat that's made for me!

He, whofe nervous paw can take My lady's lapdog by the neck; With furious hifs attack the hen, And fnatch a chicken from the pen. If the treacherous fwain thould prove Rebellious to my tender love, My fcorn the vengeful paw thall dart, Shall tear his fur, and pierce his heart.

\section{Chorus.}

Qu-ow wow, quall, wawl, moop.

Deign, moft adorable charmer, to pur your affent to this my requeft, and believe me to be with the profoundeft refpect, your true admirer.

\section{Snow*.}

* The cat, to whom the above letter was addreffed, had been broken of her propenfity to kill birds, and lived 
Anfwer.

Palace, Lichfield, Sept. 8, 1780.

$I$ am but too fenfible of the charms of Mr. Snow ; but while I admire the fpotlers whiteners of his ermine, and the tygerftrength of his commanding form, I figh in fecret, that he, who fucked the milk of benevolence and philofophy, thould yet retain the extreme of that fierceners, too juftly imputed to the Grimalkin race. Our hereditary violence is perhaps commendable when we exert it againft the foes of our protectors, but deferves much blame when it annoys their friends.

The happincls of a refined education

feveral years without molefting a dove, a tame Iark, and a redbreoft, all which ufed to fly about the room where the cat was daily admitted. The dove frequently fat on puffey's back, and the little birds would peck fearlefsly from the plate in which the was eating. 
was mine; yet, dear Mr. Snow, my advantages in that refpect were not equal to what yours might have been: but, while you give unbounded indulgence to your carnivorous defires, I have fo far fubdued mine, that the lark pours his mattin fong, the canarybird varbles wild and loud, and the robin pipes his farewell fong to the fetting fun, unmolefted in my prefence; nay, the plump and tempting dove has repofed fecurely upon my foft back, and bent her gloffy neck in graceful curves as the walked around me.

But let me haften to tell thee how my fenfibilities in thy favor were, laft month, unfortunately repreffed. Once, in the noon of one of its moft beautiful nights, I was invited abroad by the ferenity of the amorous hour, fecretly ftimulatcd by the hope of meeting my admired Perfian. With filent fteps I paced around the dimly-gleaming leads of the palace. I had acquired 
acquired a tafte for fcenic beauty and poetic imagery, by liftening to ingenious obfervations upon their nature from the lips of thy own lord, as I lay purring at the feet of my miftrefs.

I admired the lovely fcene, and breathed my fighs for thee to the liftening moun. She threw the long fhadows of the majeftic cathedral upon the filvered lawn. I beheld the pearly meadows of Stow Valley, and the lake in its bofom, which, reflecting the Junar rays, feemed a fheet of diamonds. The trees of the Dean's Walk, which the hand of Dulnefs had been reftrained from torturing into trim and deteftable regularity, met each other in a thoufand various and beautiful forms. Their liberated boughs danced on the midnight gale, and the edges of their leaves were whitened by the moonbeams. I defcended to the lawn, that I might throw the beauties of the valley into perfpective 
perfpective through the graceful arches, formed by their meeting branches. Suddenly my ear was: ftartled, not by the voice of my lover, but by the loud and diffonant noife of the war-fong, which fix black grimalkins were raifing in honor of the numerous victories obtained by the Perfian, Snow; compared with which, they acknowledged thofe of Engliph cats had little brilliance, eclipfed, like the unimportant victories of the Howes, by the puifiant Clinton and Arbuthnot; and the ftill more puiffant Cornwallis. It fung: that thou didit owe thy matchlefs might. to thy lineal defcent from the invincible Alexander; as he derived his more than mortal valour from his mother Olympia's illicit commerce with Jupiter. They fung that, amid the renowned fiege of Perfepolis, while Roxara and Statira were. contending for the honour of his attentions, the conqueror of the world deigned 
to beftow them upon a large white female cat, thy grandmother, warlike Mr. Snow, in the ten thoufandth and ninety-ninth afcert.

Thus far their triumphant din was mufic to my ear; and even when it fung that lakes of milk ran curdling into whey, within the ebon concave of their pancheons, with terror at thine approach; that mice fquealed from all the neighbouring garrets; and that whole armies of Norway rats, crying out amain, "the "devil take the hindmort," ran violently into the minfter-pool, at the firft gleam of thy white mail through the fhrubs of Mr. Howard's garden.

But $\mathrm{O}$ ! when they fung, or rather yelled, of larks warbling on funbeams, fafcinated fuddenly by the glare of thine eyes, and falling into thy remorfelefs talons; of robins, warbling foft and folitary upon the leaflefs branch, till the pale cheek of winter dimpled into joy; of hundreds of thofe bright 
bright breafted fongfters, torn from their barren fprays by thy pitilers fangs!-Alas! my heart died within me at the idea of fo prepofterous a union!

Marry you, Mr. Snow, I am äfraid I cannot; fince, though the laws of our community might not oppofe our connection, yet thofe of principle, of delicacy, of duty to my miftrefs, do very powerfully oppofe it.

As to prefiding at your concert, if you extremely wifh it, I may perhaps grant your requeft; but then you muft allow me to fing a fong of my own compofition, applicable to our prefent fituation, and fet to mufic by my fifter Sophy at Mr. Brown's the organift's, thus,

Air :-affettuofo.

He, whom Puffy Po detains

A captive in her filken chains,

Muft curb the furious thirft of prey,

Nor rend the warbler from his fpray! 
Nor let his wild, ungeherous ráge

An unprotected foe' engage.

o, . Thould cat of Darwir prove

Foe to pity, foe to love!

Cat, that liftens day by day,

To mercy's mild and horried lay,

Too furely would the dire difgrace

More deeply brand our future race,

The ftigma fix, where'er they range,

That cats can ne'er their nature change.

Should I confent with thee to wed, Thefe fanguine crimes upon thy head, And ere the wifh'd reform I fee, Adieu to lapping Seward's tea!

Adieu to purring gentle praife

Charm'd as the quotes thy mafter's lays !Could I, alas ! our kittens bring Where fweet her plumy favorites fing, Would not the watchful nymph efpy Their father's fiercenefs in their eye, And drive us far and wide away, In cold and lonely barn to ftray ?

Where the dark owl, with hideous fcream, Shall mock our yells for forfeit cream, As on ftarv'd mice we fwearing dine, And grumble that our lives are nine.

\section{Chorus :-largo.}

757. Waal, woee, trone, moan, mall, oll, moule. 
The ftill too much admired Mr. Snow will have the goodnefs to pardon the freedom of thefe expoftulations, and excufe their imperfections. The morning, O Snow! had been devoted to this my correfpondence with thee, but I was interrupted in that employment by the vifit of two females of our fpecies, who fed my ill-ftarred paffion by praifing thy wit and endowments, exemplified by thy elegant letter, to which the delicacy of my fentiments obliges me to fend fo inaurpicious a reply.

\section{I am, dear Mr. Snow, Your ever obliged,}

Po Felina. 


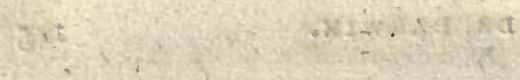

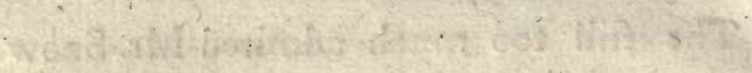

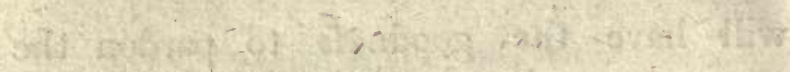

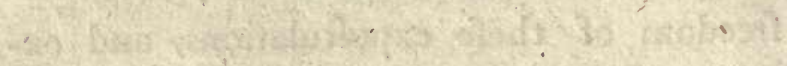

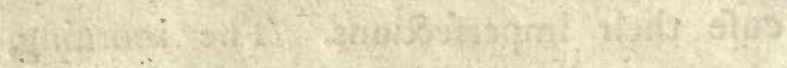

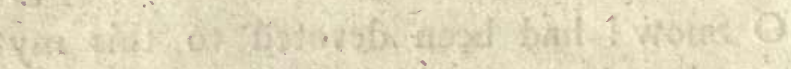

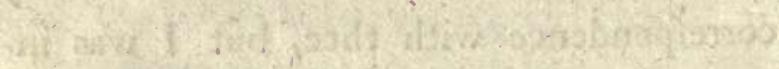

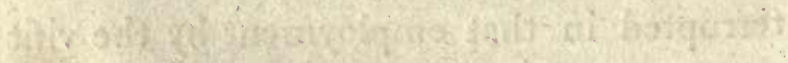

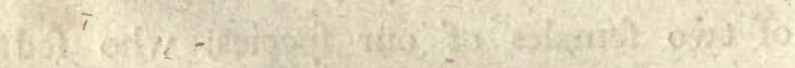

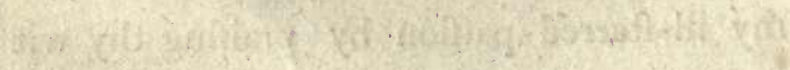

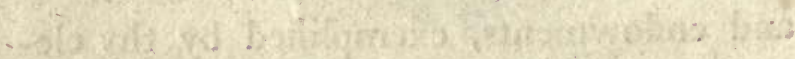

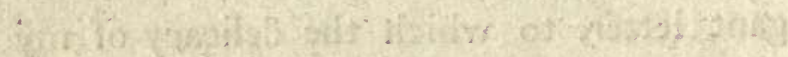

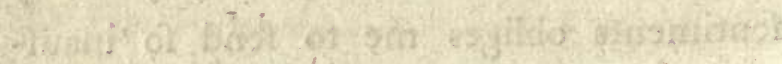
(5)

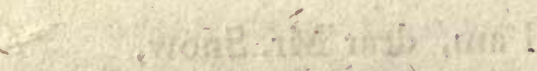

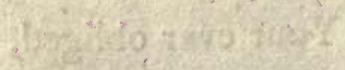

Diflogioge 


\section{CHA PTER IV.}

DuRING the courfe of the year I 780 , died 'Colonel Pole. Dr. Darwin, more fortunate than Petrarch, whofe deftiny his own had refembled in poetic endowment and hopelefs love, then faw his adored Laura free, and himfelf at liberty to court her favor, whofe coldnefs his mufe had recorded; to " drink fofter effu"fion from thofe eyes," which duty and difcretion had rendered repulfive. $\mathrm{He}$ foon, however, faw her furrounded by rivals, whofe time of life had nearer parity with her own, yet in its fummer bloom, while his age nearly approached its halt century; whofe fortunes were affluent and 
patrimonial; while his were profeffional; who were jocund bachelors, while he had children for whom he muift provide.

Colonel Yole had numbered twice the years of his fair wife. His temper was faid to have been peevifh and fufpicious, yet not beneath thofe circumftances had her kind and cheerful attentions to him grown cold or remifs. He left her a jointure of fix hundred pounds per annum; a fon to inherit his eftate, and two female children amply portioned.

Mrs. Pole, it has already been remarked, had much vivacity and fportive humor, with very engaging franknefs of temper and manners. Early in her widowhood the was rallied in a large company upon Dr. Darwin's paffion for her, and was afked what he would do with her captive philofopher. "He is not very fond of " churches, I believe, and if he would go - there for my fake, I. Thall fcarcely fol"low. 
"low him. He is too old for me.""Nay, madam, what are fifteen years on "the right fide?" She replied, with an arch fmile, "I have had fo much of that "right fide!"

Whe confeffion was thought inaufpicious to the Doctor's hopes; but it did not prove fo; the triumph of intelled was complete. Without that native perception and awăkmed tafte for literary excellence, which the firft charming Mrs. Darwin poffeffed, this lady became tenderly fenfible of the flattering difference between the attachment of a man of genius, and wide celebrity, and that of young fox-hunting efquires; dafhing militaries, and pedantic gownfmen; for the was faid to have fpecimens of all thefe claffes in her train. They could fpeak their own paffion, but could not immortalize her charms. However benevolent, friendly, and fweet-tempered, the was not perhaps exactly the woman to, have exclaimed with Akenfide, 
"Mind, mind alone, bear witnefs earth and heaven!

"The living fountain in itfelf contains

"Of beauteous and fublime!

Yet did her choice fupport his axiom when the took Dr. Darwin for her hufband. Darwin, never handfome, or perfonally graceful, with extremely impeded utterance; with hard features on a rough furface; older much in appearance than in reality; lame and clumfy - and this, when half the wealthy youth of Derby- Mire were faid to have difputed the prize with him.

But it was not without fome ftipulations, apparently hazardous to his pecuniary intereft, that Mrs. Pole was perfuaded to defcend from her Laura-eminence to wifehood, and probably to filence for ever, in the repofe of poffeffion, thofe tender ftrains, which romantic love and defpair, and afterwards the ftimulating reftleffnefs of doubtful hope, had occafionally awakened.

During 
During that vifit to Dr. Darwin, in which Mrs. Pole had brought her fick children to be healed by his fkill, the had taken a diflike to Lichfield, and decidedly faid, nothing could induce her to live there. His addreffes did not fubdue that refolve.

After fo long and profperous a refidence, to quit that city, central in the Mercian diftrict, from whence his fame had diffufed itfelf through the circling counties, feemed a great facrifice; but the philofopher was too much in love to hefitate one moment. He married Mrs. Pole in $1.78 \mathrm{I}$, and removed directly to Derby. His reputation and the unlimited confidence of the public followed him thither, and would have followed him to the metropolis, or to any provincial town, to which he might have chofen to remove.

Why he conftantly, from time to time, withftood folicitations from countlefs families of rank and opulence, to remove to 
London, was never exaclly underftood by the writer of thefe memoirs. She knows that the moft brilliant profpects of fuccefs in the capital were opened to him, from various quarters, early on his refidence at Lichfield, and that his attention to them was perpetually requefted by eminent people. Undoubtedly thofe profpects acquired added ftrength and luftre each year beneath the ever-widening fpread of his fame. Confcious of his full habit of body, he probably thought that the eftablifhed cuftom of imbibing changed and pure air by almoft daily journies into the country, effential to his health; perhaps to the duration of his life. In allufion to that perpetual travelling, a gentleman once humoroufly directed a letter "Dr.Darwin upon the road.". When himfelf wrote to Dr. Franklin, complimenting him on having united philofophy to modern feience, he directed his letter merely 
merely thus, "Dr. Franklin, America ;" and faid, he felt inclined to make a ftill more flattering fuperfeription. " Dr. "Franklin, the World." His letter reached the fage, who firft difarmed the lightning of its fatal power, for the anfwer to it arrived, and was fhown in the Darwinian circles; in which had been queftioned the likelihood of Dr. Franklin ever receiving a letter of fuch general fuperfcription as the whole weftern empire. Its fafe arrival was amengft the triumphs of genius combined with exertion, "they " make the world their country."

From the time of Dr. Darwin's marriage and removal to Derby, his limited biographer can only trace the outline of his remaining exiftence; remark the dawn and expanfion of his poctic fame, and comment upon the claims which fecure its immortality. The lefs does the regret. this limitation, as Mr. Dewhurft Billoury, 
his pupil in infancy, his confidential friend, and frequent companion through ripened youth, is now writing at large, the life of Dr. Darwin, who once more became an happy hufband, with a fecond family of children, fpringing faft around him. To thofe children the Mifs Poles, is themfelves grew up to womanhood, were very meritorioufly attentive and attached. The eldeft Mirs Pole married Mr. Bromley, and is faid to be happy in her choice of a worthy and amiable man. The fecond Mifs Pole gave her lovely felf to Mr. John Gifborne, younger brother to the celebrated moralift and poet of that name.

Mr. John Girborne's philofophic energies, poetic genius, extenfive benevolence, ingenuous modefty, and true piety, render him a pattern for all young men of fortune, and an honor to human nature. In the year $179 \%$, he publifhed a fpirited and elegant local poem, entitled, "The Vales of Weaver." 
Weaver." It is evidently of the Darwinian fchool, though in a thorter meafure, and has genius to fupport the peculiar manner of poetic writing which it emulates and has caught. In this poem we meet appropriate and vivid landfcape. Some of the epithets are perhaps exceptionable, and too free ufe is made of the word glory in feveral inftances, particularly in its application to moon-light. Pope's faulty, though admired fimile, in the laft paffage of the 8 th book of the Iliad, has mifled fucceeding poets; inducing them to lavifh upon the lunar effufions thofe terms of fuperlative fplendor which they fhould referve for the fun in his ftrength. The Bard of Twickenham, fo generally difcriminating, is indifcriminate when he ftyles the moon "refulgent lamp of night," and its white and modeft beams " a flood of " glory." Scholars fay, he found no example in the original paffage for this fundefraud. 
defrauding magnificence. We do not find it for the moon in Cowper's more literal tranflation of the Homeric landfcape, two fins againft truth pardoned, and the fcene, as penciled by Cowper, is beautiful; thus :

$\Lambda s$ when around the clear; bright moon, the ftars Shine in full fplendor, and the winds are huth'd, The groves, the mountain tops, the headland heights, Stand all apparent; not a vapor ftreaks The boundlefs blue, but æther, open'd wide, All glitters, and the Thepherd's heart is cheer'd.

Surely the original does not fanction an image which nature never prefents, fince, when the moon is clear and bright, the ftars do not fpangle the firmament plenteoufly, or fplendidly. A few ftars, and never more than a few, fometimes glimmer through her flood of fnowy and abforbing light. At any rate, fplendor is a falfe term. When the night is cloudlers, and the moon abfent, the ftellar hoft glows 
and fparkles very brightly; but it's refulting mafs of light by no means amounts to fplendor.

Nature hallows, and poetry confecrates all the moon-light fcenery in Milton. It is never more charming than in the following inftance.

Now glow'd the firmament

With living faphirs. Hefperus, that led

The ftarry hoft, rode brighteft, till the moon,

Rifing in clouded majefty, o'er all

Apparent queen, unveild her peerlefs light,

And o'er the dark her filver mantle threw.

Since Pope and Cowper, as tranllators of Homer, have been brought into a degree of comparifon on thefe pages, the writer of them cannot refift the avowal of her opinion, that, on the whole, and confidered merely as poems, great fuperiority is with Pope, as to perfpicuity, elegance, and intereft; the grace of picture, and the har- 
mony of numbers. In a few ftriking paffages Cowper may be the nobler, but his mufe is for ever vifibly and awkwardly. ftruggling for literality, where he fhould have remembered the painter's adage, "It " is better to fin againft truth than " beauty," fo long as the fenfe is not perverted, and nature is not outraged by inappropriate epithets, which muft always injure the diftinctnefs of imagery and landfcape.

If, in the preceding infance, Cowper's moon-light is chafter than Pope's, fee how much more grandly the rhyme tranflation gives the remaining lines of that clofing paffage.

So numerous feem? thofe fires, the bank between Of Zanthus, blazing, and the fleet of Greece, In profpect all of Troy; a thoufand fires Each watch'd by fifty warriors, feated near. The fteeds befide the chariot ftood, their corn Chewing, and waiting till the golden-thron'd Aurora thould reftore the light of day.

COWPER'S HOMER, Firft Edition.

Nothing 
Nothing can be more confufed and unhappy than the language of this paffage. It is left doubtful whether it is the fires that are blazing, or the river that by reflection blazes; and, "the bank between," is ftrange language for "between the banks." Chewing feems below the dignity of heroic verfe, and the compound epithet golden-thron'd, fine in itfelf, is ruined as to effect, by clofing the line when its fubftantive begins the next. Obferve how exempt from all thefe faults is Pope's tranflation of the fame paragraph.

So many' flames before proud Ilion blaze, And lighten glimmering Zanthus with their rays.

The long reflection of the diftant fires

Gleam on the walls, and tremble on the fpires.

A thoufand piles the dufky horrors gild, And thoot a thady luftre o'er the field. Full fifty guards each flaming pile attend, Whofe umber'd arms, by fits, thick flafhes fend. Lond neigh the courfers o'er their heaps of corn, And ardent warriors wait the rifing morn. 
Poetry has no picture more exquifite than we meet in the fecond, third, and fourth lines; but an infinite number, equally vivid and beautiful, rife to the reader's eye, as it explores the pages of Doctor Darwin's Batanic Garden.

While the powers of metrical landfcapepainting are the theme, not unwelcome to thofe who feel its inchantment, will be inftances which muft prove that they are poffefled by Mr. John Gifborne in a degree which would difgrace the national tafte if they thould be fuffered to pafs away without their fame. "The Vales of Weaver" is this young man's firft publication. Beneath thanklefs neglect the efflorefcence of a rich imagination will probably fink blighted, like the opening flowers of the fpring before an eaftern mildew, no more to rife in future compofitions to the view of that public which had eftimated fo coldly the value of the firft. 
We have read various defcriptions of a winter's night, and it's enfuing morning; but the following fketch is not borrowed from any of them. We feel that it was drawn beneath a lively remembrance of real impreffion made on the author's mind by the circumftances themfelves; therefore, it will not fail to touch the vibrating chords of recollected fenfation in every reader of fenfibility. Book-made defcriptions are trite and vapid; but nature is inexhauftible in her varieties, and will always prefent to the eye of genius either new images, or fuch combination of images as muft render them new ; and they will rife on his page in the morning frefhnefs of originality. Thefe facred arcana the referves for the poet, and leaves the mere verfifier to his dull thefts.

VALES OF WEAVER.

O Wootton! oft I love to hear

Thy wintry whirlwinds, loud and clear;

With dreadful pleafure bid them fill

My liftening ear, my bofom chill. 


\section{As the fonorous North affails}

Weaver's bleak wilds, and leaflers vales,

With awful majefty of might

He burfts the billowy clauds of night;

Booms * the refounding glens among,

And roaring rolls his fnows along.

In clouds againft my groaning fath

Broad, feathery flakes inceffant dafh,

Or wheel below, and mingling form

The frolic pageants of the ftorm.

Hark ! with what aggravated roa:

Echo repeats her midnight lore;

Rends her dark folitudes and caves,

And bellowing thakes the mighty graves $t$.

Couch'd on her feat the timid hare Liftens each boifterous fweep of air; Or peeps, yon blafted furze between, And eyes the fnow-bewildered fcene; Inftant retracts her fuuddering head, And neftles chofer in her bed.

All fad and ruffled, in the grove

The fieldfare wakes from dreams of love;

Hears the loud north and fleety fnow, And views the drifted brakes below;

- A word admirably expreffing the noife of winds, and applied to it here for the firft time in poetry.

+ The numerous tumuli on Weaver and the adjacent hills. 
Swift to her wing returns her beak,

And thivers as the tempefts break.

Up ftarts the village-dog aloof,

And howls beneath his rifted roof;

Looks from his den, and blinking hears

The driving tumult at his ears !

Inftant withdraws his fearful breaft,

Shrinks from the ftorm, and fteals to reft.

So * Thrinks the pining fold, and fleeps

Beneath the valley's vaulted deeps;

Or crops the fefcue's dewy blade,

And treads unfeen the milky glade;

Forms by it's breath fair opening bowers,

Tranfparent domes, and pearly thowers.

Thus night rolls on till orient dawn

Unbars the purple gates of morn,

Unfolds each vale and fnow-clad grove,

Mute founts and gloffy banks above.

* So flrinks the pining fold.]. It often happens that meep in this and in the Peak country, are immerfed many feet deep in fnow for feveral days before they are difcovered. The perpetual fteam from their noftrils keeps the fnow, immediately over their heads, in a diffolving ftate, and hence a tunnel is conftantly forming through the heaps above. This tunnel greatly facilitates their difcovery, and fupplies them with abundance of frem air. The warmth of thefe animals foon diffolves the furrounding fnow, and at length the drift is fo completely vaulted, that they are able to ftretch their limbs, and fearch for fubfiftence. It is afferted that theep have been frequently found alive after having been entombed in the fnow during a fortnight. 
Thin ftreaky clouds, convex'd by fturms, Slowly expand their tiffued forms;

Long bars of grey and erimfon bright

Divert the golden threads of light;

Till glory's nafcent curve difplays

One fplendid orb, a world of rays !

Then lightens heaven's etherial bound, And all the fpangled country glows around.

Now that we have obferwed what power this author poffeffes to bring back to our recollection a ftormy night.in winter, fucceeded by a ruddy dawn, blazing upon it's frofted landfcape, let us turn to his mifty morning, in the fame feafon, gradually clearing up into a mild and funny day.

When Winter's icy hand

Whitens Britannia's thivering land, Then flow the billowy vapors glide, And roll their lazy oceans wide.

Oft have I mark'd from Mathfield's brow,

Her mitt-embofom'd realms below,

While, here and there, a foaring tree

Waded amid the vapory fea, And Ambourn's fpire to diftant fight Tower'd, like a maft, in dubious light. 
If, through the paly gloom, the fun

With ftriggling beams his journey won,

Soon as he rais'd his crimfon eye

With tranfport flafh'd th' illumin'd $\mathrm{Aky}_{\text {; }}$

The vane, rekindling at his blaze,

Shot, like a meteor, through the haze;

The trees in liquid luftre flow'd,

And all the dim tranfparence glow'd,

*.

The ruftic, on his fields below,

Shoves from his lot the melting fnow;

Salutes the welcome change, and feems

To tafte of life's diviner ftreams;

Breathes with delight the temperate air,

And views, with half-clos'd eyes, the boundlefs glare.

What a pretty fummer fcene rifes in the following verfes from the fame poem!

\section{- Wide, fpread}

An elm uprears his reverend head;

* $\Lambda$ Lapland fcene, which fucceeds to the laft line, is omitted, not from its want of poetic beauty, but merely to fhorten the quotation. 
His front the whifpering breeze receives, The blue fky trembles through it's leaves;

A cottage group beneath his thade, Their locks with flowers and ruhes braid; And, gurgling round dark beds of fedge, A brook juft fhows it's filver edge.

But now, turning from The Vales of Weaver, let us feek the Botanic Garden. The commencement of that poem in 1779 has been previoufly mentioned, with the circumftance which gave it birth. It confifts of two parts; the firft contains the Economy of Vegetation, the fecond the Loves of the Plants. Each is enriched by a number of philofophical notes. They ftate a great variety of theories and experiments in botany, chemiftry, electricity, mechanics, and in the various fpecies of air, falubrious, noxious, and deadly. The difcoverics of the modern profeffors in all thofe fciences, are frequently mentioned with praife highly gratifying to them. In 
thefe notes explanations are found of every perfonified plant, it's generic hiftory, it's local fituation, and the nature of the foil and climate to which it is indigenous; it's botanic and its common name.

The verfe corrected, polifhed, and modulated with the moft fedulous attention; the notes involving fuch great diverfity of matter relating to natural hiftory; and the compofition going forward in the fhort receffes of profeffional attendance, but chiefly in his chaife, as he travelled from one place to another, the Botanic Garden could not be the work of one, two, or three years; it was ten from its primal lines to its firf publication. The immenfe price which the bookfeller gave for this work, was doubtlefs owing to confiderations which infpired his truft in it's popularity. Botany was, at that time, and ftill continues a very fafhionable ftudy. Not only philorophers, but fine ladies and gentlemen, fought 
to explore it's arcana. This poem, therefore, involved two claffes of readers by whom it would probably be purchafed. Every fkilful Botanift, every mere Tyro in the fcience, would wifh to poffefs it for the fake of the notes, though infenfible, perhaps, as the verieft ruftic, to the charms of poetry; while every reader, awakened to them, muft be ambitious to fee fuch a conftellation of poetic ftars in his library; all that gave immortality to Ovid's fame, without the flighteft imitation of his manner, the leaft debt to his ideas; fince, though Dr. Darwin often retells that poet's ftories, it is always with new imagery and heightened intereft.

Cerrtainly it was by an inverfion of all cuftom that Dr. Darwin publifhed the fecond part of his poem firft. The reafon given for fo extraordinary a manouvre in that advertifement which led the younger fifter before the elder on the field of pub- 
lic exhibition, is this, that the appearance of the firt part had been deferred till another year, for the purpofe of repeating fome experiments in vegetation.

The Doctor was accuftomed to remark, that whenever a ftrange ftep had been taken, if any way obnoxious to cenfure, the alleged reafon was fcarcely ever the real motive. His own fingular management in this inftance, and the way in which he accounted for it, proved a cafe in point. He was confcious that the fecond part of his work would be more level than the firft to the comprehenfion, more congenial to the tafte of the fuperficial reader, from it's being much lefs abftract and metaphyfic, while it poffeffed more than fufficient poetic matter to cntertain and charm the enlightened and judicious few. They, however, he well knew, when his firft part fhould appear, would feel it's fuperiority to the earlier publication, it's grander conceptions, it's more fplendid - 
fplendid imagery, though lefs calculated to amufe and to be underftood by common readers. Thofe of that laft number who had purchafed the firft part would not like to poffefs the poem incomplete, and therefore would purchafe the fecond. The obfervations of this paragraph refer to the poetry of the work, and to the two claffes of readers who would value it chiefly on that account. The notes to each part muft render them equally valuable to the votaries of botany, and other modern fciences.

It is with juft and delicate criticifm that Mr. Fellowes again obferves of Dr. Darwin's poctry: "In perfpicuity, which is " one of the firft excellences in poetic as " well as profe compofition, this author " has perhaps few equals. He is clear, " even when defcribing the moft intricate " operations of nature, or the mort com" plex works of art; and there is a lucid "tranf-. 
" tranfparency in his ftyle through which

"we fee objects in their exact figure and

" proportion; but Dr. Darwin's poetry

"wants fenfation; that fort of excellence

" which, while it enables us to fee dif-

" tinctly the objects defcribed, makes us

" feel them acting on our nerves."

A little reflection is, perhaps, neceffary precifely to underftand this criticifm, diftinguinhing between vivid poetry which does not excite fenfation, and vivid poetry which does excite it. Inftances will beft elucidate the diftinction. See the two following defcriptions of a wintery evening, late in autumn.

\section{BOTANIC GARDEN,}

Then o'er the cultur'd lawns and dreary wafte, Retiring Autumn flings her howling blaft,

Bends in tumultuous waves the ftruggling woods, And thowers her leafy honors on the floods, In withering heaps collects the flowery fpoil, And each chill infect neeps beneath the foil. 
Quoted from a fonnet of Mr. C. Lloyd's publined with Mr. Colridge's poems.

Difmal November $1 \mathrm{me}$ it fooths to view,

At parting day, the fcanty foliage fall

From the wet fruit-tree, or the grey ftone wall, Whofe cold films gliften with unwholefome dew;

To watch the fweepy mifts from the dank earth

- Enfold the neighbouring copfe, while, as they pafs,

The filent rain-drop bends the long, rank grafs, Which wraps fome bloffom's immatured birth;

And, through my cot's lone lattice, glimmering grey,

Thy damp chill evenings have a charm for me,

Difmal November!

The picture is equally juft and ftriking in both the above quotations; but the firft, though more dignified, does not thrill our nerves, and the fecond does. We admire in the former the power and grace of the poet; in the latter we forget the poet and his art, and only yearn to fee images reflected in his mirror, which we have annually, and many times fhuddered to furvey in real life.

When 
When Dr. Darwin defcribes the glowworm, fuppofing it's light to be phofphoric, he thus exhorts his allegoric perfonages, the nymphs of fire, meaning the electrical - powers.

Warm, on her moffy couch, the radiant worm, Guard from cold dews her love-illumin'd form, From leaf to leaf conduet the virgin light, Star of the earth, and diamond of the night!

Nothing can be more poetic, more brilliant than this picture; yet, when Shakefpear fays,

"The glow-worm fhows the morning to be near,

"And 'gins to pale his ineffectual fire,"

we feel fenfation which the more refplendent picture of this infect had failed to infpire, notwithftanding the pleafure it had given us, the admiration it had excited.

Probably the reafon why Dr. Darwin's poetry, 
poetry, while it delights the imagination, leaves the nerves at reft, may be, that he feldom mixes with the picturefque the (as it is termed in criticifm) moral epithet, meaning that quality of the thing mentioned, which pertains more to the mind, or heart, than to the eye, and which, inftead of picture, excites fenfation. Shakefpear gives no diftinct picture of the glowworm, fince the only epithet he ufes for it is not defcriptive of its appropriate luftre, which has a tint fpecified in the enfuing quotation.

of From the bloom that fpreads

" Refplendent in the lucid morn of May,

of To the green light the little glow-worm fheds

" On mofly banks, when midnight glooms prevail,

" And Silence broods o'er all the fhelter'd dale."

If Dr. Darwin alfo omits to mention the particular hue of this infect, when it is luminous, he conveys that hive to the imagi- 
inagination when he fays, "Star of the " earth," fince the largeft and brighteft ftars have the fame mafter-tint. Offian fays, "Night is dull and dark, no ftar "with its green, trembling beams!".

But Shakefpear's moral epithet, ineffectual, does better than paint it's object. It excites a fort of tender pity for the little infect, lhining without either warmth or ufeful light, in the dark and lonely hours.

BOTANIC GARDEN.

And now the rifing moon, with luftre pale, O'er heaven's dark arch unfurls her milky veil.

This picture is charming: yet when Milton paints the fame object thus,

$$
\text { s- Now reigns, }
$$

"Full orb'd, the moon, and with more pleafant light, "shadowy, rets off the face of things,"

the charm is on the nerves, as well as on the 
the eye. The moral epithet pleafant, excites fenfation, while the picturefque epithet, fhadowy, has all the truth, the grace, and power of the pencil. It is that charm on the nerves to which Mr. Fellowes fo well applies the word, fenfation. It feems a new term in criticifm, and is ufeful to exprefs what pathos would exprefs too ftrongly, and therefore with lefs accuracy. Pathos is the power of affecting the heart; by fenfation is meant that of acting upon the nerves.

Beneath their torpor, the heart, or the paffions, cannot be affected; but the nerves may be awakened to lively, or penfive pleafure, by compofition which, not exciting any pofitive paffion, may not act upon the heart in a degree to juftify the application of the word, pathetic; and for this gentler, fubtler, and more evanefcent influence, which almoft imperceptibly touches the paffions 
paffions without agitating them, Mr. F.'s term is happy.

Dr. Darwin's excellence confifts in delighting the eye, the tafte, and the fancy, by the ftrength, diftinctnefs, elegance, and perfect originality of his pictures; and in delighting the ear by the rich cadence of his numbers; but the paffións are generally afleep, and feldom are the nerves thrilled by his imagery, impreflive and beauteous as it is, or by his landfcapes, with all their vividnefs.

It may, however, be juftly pleaded for his great work, that it's ingenious and novel plan did not involve any claim upon the affections. We are prefented with an highly imaginative and fplendidly defcriptive poem, whofe fucceffive pictures alternately poffefs the fublimity of Michael Angelo, the correctnefs and elegance of Raphael, with the glow of Titian; whore landfcapes have, at times, the ftrength of 
Salvator, and at others the foftnefs of Claude; whofe numbers are of ftately grace, and artful harmony; while its allufions to ancient and modern hiftory and fable, and its interfperfion of recent and extraordinary anecdotes, render it extremely entertaining. Adapting the paft and recent difcoveries in natural and fcientific philorophy to the purpofes of heroic verfe, the Botanic Garden forms a new clafs in poetry, and by fo doing, gives to, the Britifh Parnaffus a wider extent than it poffeffed in Greece, or in ancient, or modern Rome.

Nor is it only that this compofition takes unbeaten ground, and forms an additional order in the fanes of the Mufes, it forms that new order fo brilliantly, that though it may have many imitators, it will probably never have an equal in it's particular clafs; neither would it's ftyle apply happily to fubjects lefs intrinfically picturefque. The fpecies 
Ipecies of praife here given to this work is all that it's author defired to excite. We have no right to complain of any writer, or to cenfure him for not poffeffing thofe powers at which he did not aim, and which are not neceffarily connected with his plan.

To the fubject Dr. Darwin chofe, his talents were eminently calculated. Neither Pope nor Gray would have executed it fo well; nor would Darwin have written fo fine an Effay on Man, fo incerefting a Churchyard, or fo lovely an Ode on the profpect of the fchool at which he was educated, had that fchool been Eaton. He would not have fucceeded fo tranicend. ently on themes, which demanded cither pathos, or that fort of tender and delicate feeling in the poet, which excites in the reader fympathetic fenfation; or yet in the facred morality of ethic poetry, which however it may admit, or require that 
fancy adorn it with fome rare, and lovely flowers, "allows to ornament but a fecond "place, and always renders it fubordinate " to intrinfic worth and juft defign." To whomfoever he might have been practically inferior on themes he has left unattempted, he is furely not inferior to Ovid; and if poetic tafte is not much degenerated, or Thall not hereafter degenerate, the Botanic Garden will live as long as the Mètamorphofes.

That in his poetic ftyle Dr. Darwin is a mannerift cannot be denied; but fo was Milton, in the Paradife Loft; fo was Young, in the Night Thoughts; fo was Akenfide, in the Pleafures of Imagination. The Darwinian peculiarity is in part formed by the very frequent ufe of the imperative mood, generally beginning the couplet either with that, or with the verb active, or the noun perfonal. Hence, the accent lies oftener on the firft fyllable of each couplet in his 
verfe than in that of any other rhymift: and it is, in confequence, peculiarly fpirited and energetic. Dr. Darwin's ftyle is alfo diftinguifhed by the liberal ufe of the fpondee, viz. * two monofyllables, equally accented, following each other inftantly in fome part of the line.

Spondees, judicioufly ufed, vary and increafe the general harmony in every fpecies of verfe, whether blank or rhyme.' They preferve the numbers from too lufcious fweetnefs, from cloying famenefs, from feeble elegance, and that, by contrafting the fmoothnefs of the dactyls, and the rich melodies of the iambic accents. So difcords refolving into concords, infpirit. the ftrains of mufical compofition. But it is poffible to make too frequent ufe of the fpondee in poetry, as of the difcord in mufic. Dr.Darwin's ear preferved him

* This explanation is for the ladies. 
from that exuberance; but Mr. Bowles, one of the fineft poets of this day, often renders his verfification, which is, at times, moft exquifitely fweet, harh, by the too frequently-recurring fpondee.

From that gentleman's verfe a couple of inftances may be felected, to fhow, in one, that harmony may be improved by a fparing ufe of that accent, and injured in the other, by ufing it too freely.

\section{MR. BOWLES HOPE.}

But lufty Enterprife, with looks of glee, Approach'd the drooping youth, as he would fay, Come to the wild woods and the hills with me, And throw thy fullen myrtle wreath away!

\section{BOWLES ELEGIAC STANZAS,}

Haft thou * not vifited that pleafant place,

Where in this hard world I have happieft been, And thall I tremble at thy lifted mace,

That hath pierc'd all on which life feem'd to lean?

* Death. 
The recurrence of two equally accented words three times in the ftanza, and twice in the laft line, incumbers the verfification, while the fingle ufe of the fpondee in the preceding four lines, from Hope, gives it grace and beauty.- Dr. Darwin, in the following pafiage, has ufed it frequently, without producing any fuch dead weight upon the verfe. The quotation is from the charge of the Botanic Queen to the Nymphs of Fire, a poetic allegory for the influence of the fluid matter of heat in forwarding the germination and growth of plants.

Pervade, pellucid forms, their cold retreat!

Ray, from bright orbs, your viewlefs floods of heat!

From earth's deep wafles electric torrents pour,

Or fhed from heav'n the fcintillating thower!

Pierce the dull root, relax its fibre trains,

Thaw the thick blood that lingers in its veins!

Melt with warm breath, the fragrant gums that bind Th' expanding foliage in its fcaly rind I 
And as in air the laughing leaflets play, And turn their. fhining bofoms to the ray, Nymphs, with fweet fmile, each opening flower invite, And on its damafk eyelids pour the light!

On reflection, it fhould feem that it is the fituation of thefe twin accents in the line, which prevents their frequent recurrence from producing harhnefs. It will be obferved in the laft quotation, that all the many fpondees are preceded by two fyllables; and that it is only when they are preceded by an odd fyllable, either one or three, that they increafe the harmony by their fparing, and injure it by their frequent appearance. One fyllable only. goes before the fpondee in this line from the Botanic Garden.

The wan fars glimmering through the filver train.

Three fyllables in this verfe from the fame poem.

Where now the South-fea heaves its wafte of froft. 
Again,

Loud firieks the lone thrufh from his leaflefs thorn.

And, in that laft inftance, the fpondee recurring twice in one line, harhnefs is the refult. Once ufed only, and the harhnefs had been avoided; thus,

And thrieks the lone thrufh from the leatlefs thorn.

The following is a couplet where the fpondee fucceeding to three monofyllables has an exquifite effect of found echoing fenfe.

\section{BOTANIC GARDEN.}

With paler luftre where Aquarius burns, And howers the fill fnow from his hoary urns.

We find another ftriking peculiarity in Dr. Darwin's ftyle, that of invariably prefenting 
fenting a clafs by an imperfonified individual; thus,

Where, nurs'd in-night, incumbent Tempeft throuds

The feeds of thunder in circumfluent clouds.

\section{Again,}

Where, with chill frown, enormous Alps alarms

A thoufand realms horizon'd in his arnss.

\section{Again,}

Sailing in air, when dark Monfoon enthrouds

His trophic mountains in a night of clouds.

Similar inftances crowd the pages of the Botanic Garden. There is extreme fublimity in the whole of that paffage, which converts the monfoon winds into an individual monfter,

That fhowers on Afric all his thoufand urns.

Dr. Johnfon, Mr. Burke, and Dr. Parr, have the fame habit in their profe; "Cri" ticifm pronounces," inftead of " Critics

"pronounce." 
"pronounce." " Malignance will not " allow," inftead of "Malignant people " will not allow." " Good-nature refufes "to liften," inftead of " a good natured " man refufes to liften," and fo on.

This manner of writing, whether in verfe or profe, fweeps from the polifhed marble of poetry and eloquence, a number of the fticks and ftraws of our language : its articles, conjunctives, and prepofitions. Addifon's ferious Effays are fo littered with them and with idioms, as to render it ftrange that they fhould ftill be confidered as patterns of didactic oratory. No man of genius, however, adopts their diffure and feeble ftyle, now that the ftrength, the grace, and harmony of profewriting, on the dignified examples of our later effayifts, fenators, and pleaders, give us better examples. Thefe obfervations relate folely to the grave compofitions of the celebrated Atticus. The quiet, eafy, 
elegant gaiety of his comic papers in the Spectator, remains unrivalled.

It has been already obferved in the courfe of this tract, that Dr. Darwin's mufe ranges through nature and art, through hiftory, fable, and recent anecdote, to vary, infpirit, and adorn this her luxuriant work. If the imperfonizes too lavinhly; if devoted to picture, the covers every inch of the walls of her manfion with landfcapes, allegoric groups, and with fingle figures; if no infterfticial fpace is left to increafe the effect of there fplendid forms of the imagination: yet be it remembered, that it is always in the reader's power to draw each picture from the mars, and to infulate it by his attention. It will recompenfe by its grandeur, its beauty, or its terrific grace, the pains he may take to view it in every light, ere he proceeds to examine other objects in the work, which he will find of equal force and fkill in their formation. 
Dr. Darwin gives us, in this poem, claffic fables from Homer, Virgil, and Ovid, and $f_{0}$ gives them, places the perfons of each little drama in fuch new and interefting fituations and attitudes, that he muft indeed be a dull profe-man who thall exclaim undelighted, "This is an old ftory." 


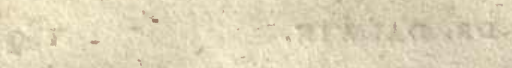

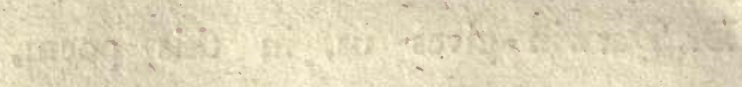

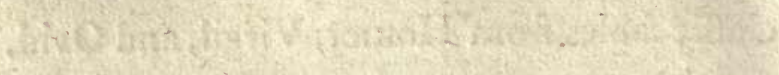

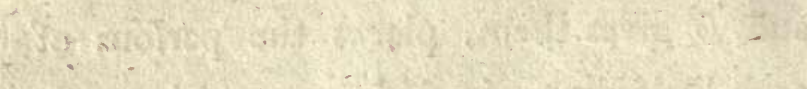

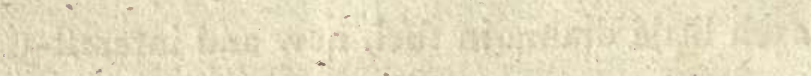

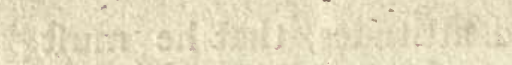

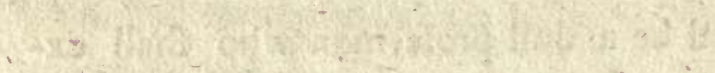

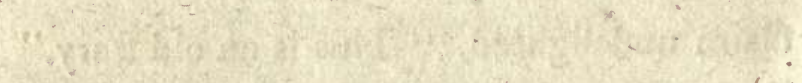

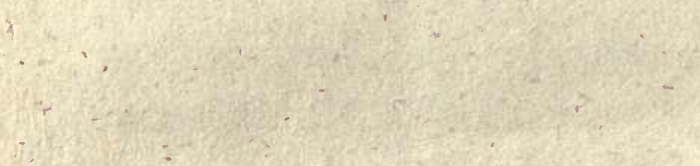

(a) 110 s 


\section{CH A P T E R V.}

ANALYsis of the firft part of the Botanic Garden.

\section{THE ECONOMY OF VEGETATIOI.}

After that landfcape of the fcene which forms the exordium, the Goddefs of Botany defcends in gorgeous gaiety.

She comes!-the Goddefs!-thro the whifpering air, Bright as the morn, defcends her blufhing car; Each circling wheel a wreath of flowers entwines; And gemm'd with flowers the filken harnefs thines; The golden bits with flowery ftuds are deck'd, And knots of flowers the crimfon reins connect. And now on earth the filver axle rings, And the fhell finks upon it's nender fprings; Light from her airy feat the Goddefs bounds, And fteps celeftial prefs the panfied grounds. 
Spring welcomes her with fragrance and with fong, and, to receive her commiffions, the four Elements atterid. They are allegorifed as Gnomes, Water-Nymphs, Sylphs, and Nymphs of Fire. Her addrefs to each clafs, and the bufinefs the allots to them, form the four Cantos of this firft part of the poem.

The Ladies of Ignition receive her primal attention. The picture with which her addrefs commences; is of confummate brilliance and grace ; behold it, reader, and judge if this praife be too glowing!

Nymphs of primeval fire, your veftal train Hung with gold treffes o'er the vaft inane; Pierc'd with your filver fhafts the throne of night, And charm'd young Nature's opening eyes with light, When Love Divine, with brooding wings unfurl'd, Call'd from the rude abyfs the living world.

The Darwinian creation, which enfues, charms us infinitely, even while we recol- 
lect its frmpler greatnefs on the page of Mofes, and on its fublime paraphrafe in the Paradife Loft. The creation in this poem is aftronomic, and involves the univerfe; and as fuch is of excellence yet unequalled in its kind, and never to be excelled in the grandeur of its conceptions.

Let there be light, proclaim'd th' Almighty. Lord, Aftonifh'd Chaos heard the potent word; Through all his realms the kindling ether runs, And the mafs ftarts into a million funs. Earths round each fun, with quick explofion, burft, And fecond planets iffue from the firft; Bend, as they journey, with projectile force, In bright ellipfis, their reluctant courfe;

Orbs wheel in orbs, round centres centres roll, And form, felf-balanc'd, one revolving whole; Onward they move, amid their bright abode, Space without bound, the bofom of their God.

The word of the Creator, by an allufion to the effects of a fpark upon gunpowder, fetting into inftant and univerfal blaze the ignited particles in Cháos, till they burft into count- 
lefs funs, is an idea fublime in the firft degree.

The fubfequent comments of the Goddefs on the powers of the nymphs of fire, introduce lovely pictures of the lightning and the rainbow; the exterior $1 \mathrm{ky}$, the twilight, the meteor, and the aurora-borealis ; of the planets, the comet, and all the etherial blazes of the univerfe.

She next exhibits them as fuperintending the fubterranean and external volcanos.

You, from deep cauldrons and unmeafur'd caves,

Blow flaming airs, or pour vitrefcent waves;

O'er fhining oceans ray volcanic light,

Or hurl innocuous ember' 3 through the night.

She compares them to Venus and her Nymphs, after they had defcended to the cave of Vulcan. The claffic fable forms a varied and lively little drama. The Goddefs proceeds to remind her hand-maids of their employments; fays, they lead their glittering 
glittering bands around the finking day, and when the fun retreats, confine, with folds of air, his lingering fires to the cold bofom of earth.

O'er eve's pale forms diffufe phofphoric light, And deck with lambent flames the forine of night.

Surely there cannot be a more beautiful defcription of a vernal twilight. The phorphorefcent quality of the Bolognian ftone, Beccari's prifmatic Thells, and the harp of Memnon, which is recorded to have breathed Spontaneous chords when thone upon by the rifing fun, are all compared to the twilight glimmerings of the horizon; fo alfo the luminous infects, the glowworm, the fire-Hlies of the tropics, the fabulous ignis fatuus, and the gymnotus electricus, brought to England from Surinam in South America, about the year 1783 ; a firh, whofe electric power is, on provocation, mortal to his enemy. He is com-

$$
\text { ० } 2 \text { pared }
$$


pared to the Olympic eagle, that bears the lightning in it's talons.

Dr. Darwin confiders the difcovery of the ufes of fire, as the earlieft and moft important of the artificial comforts. Hence, the Goddefs praifes her nymphs of that element, as the primal inftructers of favage man. Its dangerous excellence is illuftrated by the fevere beauty of the ferpent-haired Medufa, as it blazes on the fhield of Minerva.

They are next addreffed as the patroneffes of chemiftry; teaching the ufes of gunpowder, and infpiring Captain Savery with the invention of the fteam-engine. The unpoetical name renders this introduction of a real perfon amidft allegoric beings, unhappy; efpecially fince no dranatic circumftance in his deftiny recompenfes the infelicity. A defcription of that eminently-ufeful machine is given with 
the accuracy of a mechanic philofopher, and the dignity of a great poet. A prophecy follows, that it's powers will, in future times, be applied to the purpofes of facilitating land and water carriage, and in navigating balloons.,

The wonderful effects of this vaft machine are fuppofed to refemble the exploits of Hercules, and feveral of thofe exploits are very finely pictured.

All the operations of electricity next pafs in review; a lovely female receiving the hock on a waxen elevation; alfo a circle of young men and women electrified. Their refulting fenfations are defcribed with perfect truth and elegance, and the effeets of this difcovery in paralytic cafes are thus exquifitely mentioned,

Palfy's cold hands the fierce concuffion own, And Life clings trembling on her tottering throne. 
Such powers in this artful lightning are compared to thore of the natural; its deleterious excefs, to the fire of heaven that fcathes the oak; its milder degree, to the fairy rings, which the poet believes to have been imprinted by the flathes of the thunder ftorm darting on the grafs and circularly blighting it.

The difaftrous fate of profeffor Richman, at Peterfourgh, purfuing electric experiment with fatal temerity, rifes to the eye, and makes the reader a Phuddering fpectator of its progrefs and refult.

Dr. Franklin, with his preferving rods, is compared to the celebrated Florentine gem, Cupid fnatching the lightnings from Jupiter, which the poct confiders as a noble allegory, reprefenting Divine Juftice difarmed by Divine Love. The poetic fcene, from the Gem, is one of the fweeteft little dramas of this poem; fo fweet, there 
is no refifting the temptation of here exhibiting it to thofe to whom the work itfelf may not infantly be acceffible.

Thus when, on wanton wing, intrepid Love Snatch'd the rais'd lightning from the arm of Jove, Quick o'er his knee the triple bolt he bent, The clufter'd darts and forky arrows rent; Snapp'd, with illumin'd hands, each flaming thaft, His tingling fingers thook, and ftamp'd, and laugh'd.

Bright o'er the floor the fcatter'd fragments blaz'd, And Gods, retreating, tremblẹd as they gaz'd. Th' immortal Sire, indulgent to his child, Bow'd his ambrofial locks, and Heav'n relenting, fmil'd.

Of the great fuperiority of poetic to actual picture, this paffage is one of the countlefs proofs, perceived by every reader who has power to meet the ideas of the Bard. Suppofe the fubject of this little fable to be engraven, or painted with the utmoft excellence, yet the exquifitely natural action of the infant god thaking his fingers, and laughing and ftamping, from that degree of pain experienced on lightly toruching 
touching an ignited fubftance; the fcattering over the floor the broken darts and arrows of the lightning; the alarmed deities retreating, and the indulgent nod and increafing fmile of Jupiter, are all progreffive circumftances which genius may paint on the imagination, but not on the canvafs.

The Goddefs next adverts to the influence of her nymphs on animal circulation, from the theory of the phofphoric acid colouring and warming the blood, and hence becoming an indifpenfable ingredient in vital formation

From the crown'd forehead to the proftrate weed.

This theory is illuftrated by the noble fable of Eros, or Divine Love, iffuing from the great egg of night, floating in chaos; but furely the image of this celeftial love is too gay for the fublimity of its birth; " gaudy wings, foft fmiles, golden curls, 
" and filver darts," might fuit the cyprian but not the hieroglyphic Cupid.

\section{- Higher far of him,}

And with myfterious reverence we deen.

MILTOX.

Her Nymphs thus eulogized,

The Goddefs paus'd, admir'd, with confcious pride,

Th' effulgent legions marthall'd by her fide,

Forms fpher'd in fire, with trembling light array'd,

Ens without weight, and fubftance without hade.

It may be obferved of the two laft lines that the imagination, which could with fuch appropriate and novel beauty inveft its ideal perfonages, cannot be too highly appreciated, and we might as well difdain the fun for often dazzling us with excefs of fplendor, as to fuffer the occafional redundance of ornament in this extraordinary work, to make us cold and infenfible to it's original, bold, and, in their clars, peerlefs excellences, 
The ufe of words entirely Latin has been objected to this poem, as ens, for life, in the laft verfe of the above quotation. Nieenefs of ear probably induced its fubftitution, and that from the proximity of the word light in the preceding line, which would have been of too fimilar found to life, had life been ured inftead of î́s Latin fynonifm, ens.

The Botanic Queen now proceeds to appoint the nymphs of fire their tanks. She bids them awaken the weft wind, chafe his.wan cheeks, and wring the rain-drops from his hair; bids them blaze around the frofted rills, and ftagnant waters, and charm the Naiad from her filent cave, where the fits enthrined in ice, clafping her empty urns. She is compared to Niobe.

Our Poet feems to have forgotten himfelf in thus throwing the year back into the Akirts of winter; fince, in opening this

Canto, 
Canto, he had defcribed the fprirg in all her glory, when the Botanic Queen defcended, and the imperfonized elements received her.

The nymphs are alfo commanded to affail the fiend of froft; to break his white towers and cryftal mail; to drive him to Zembla, and chain him to the northern bear. A fimile enfues, in which the grampus, and the fcene of the whale fifhery, in all the ftrength of poetic colouring, meets the attention of the reader.

Suppofed influence of the principle of internal heat in vegetation induces a command to thefe its agents to pour electric torrents from the deep waftes of earth, which may pierce the root, relax the fibres, and thaw the fap of plants, flowers, and trees. The afferted confequence of their obedience to this command produces, a noble fketch of the umbrageous wilds of

Canada. 
Canada. Their operations are oddly compared to the effects of the fympathetic inks, and of a picture drawn in them; and a receipt to make them is given in a note.

The nymphs are now exhorted to quit the fummer-regions when the dog-ftar fhall prefide in them. It's often blighting -influence on the fruits of the earth is illuftrated by an allufion to the fate of Semele. Then rifes an iceland fcene, and an aftronomic perfonification. Look at it, courteous reader, and if with eyes of indifference, arraign the power of prejudice in thy mind, or fufpect thy want of tafte for the higher orders of poetry.

There, in her azure coif, and fiarry fole;

Grey Twilight fits, and rules the fumbering Pole;

Bends the pale moon-bearn round the fparkling coati? And ftrews with livid hands eternal froft.

An agency of the ignited particles in creation, that of feparating the ice-iflands, fancifully induces a command from the Goddefs, 
Goddefs, that her nymphs fhould float their broken maftes of ice to the torrid climates. It is adorned with the feripture incident, Elijah, on mount Carmel, invoking -fire from heaven, and the incident is given with all the Darwinian power.

This Canto terminates with the obedience of the nymphs, and a fimile for their departure. They ftart from the foil, and wing their duteous flight,

While vaulted fkies, with freams of tranfient rays,

Shine as they pafs, and earth and ocean blaze.

A comparative defcription of the fireworks exhibited in great cities for the return of peace and liberty, after the cruel oppreffions of war, is of the moft accurate precifion; but it is faulty as a fimile, from it's extreme inferiority to the imaginary objects which it is meant to illuftrate. The nymphs of fire, flying on their appointed errands, in every direction, illuminating, with 
with evanefcent flafhes, the whole horizon, the fea, and the land, is fo grand an idea, that the wheels, the dragons, the ferpents, the mock ftars, and funs, of that ever childifh exhibition, become ludicrous, as fucceeding to a picture of fuch gay fublimity; for fublimity is not always confined to fombre objects. Proofs that it is not, are found in the Paradife Loft. When Adam obferves to Eve, on the approach of the angel Michael, that the glorious thape feems another morning rifen on mid-noon, the idea is no lefs fublime than it is gay.

This apprehended injudicioufners of the fire-work fimile fuggefts the remark, that a few fuch erratic luxuriances of a picturefque fancy, together with the peculiar conftruction of the Darwinian verfe, and it's lavifh perfonification, enabled an highly ingenious fatirift to burlefque the Loves of the Plants, by the Loves of the Triangles. Eminently fortunate for it's purpofe was 
the thought of transforming cubes, and cones, and cylinders, and other technical terms of mathematic and mechanic fcience, into nymphs and fwains, enamoured of each other. The verfe of this ironical poem is not only Darwinian, but it is beautifully Darwinian. The very Aightly allufive power of feveral of the fimilies in the Botanic Garden, is ridiculed with infinite fubtleners and wit; while the little ftories in this burlefque, fo comic in their fcantinefs of refemblance, are very elegantly told. That brilliant fatire amply refutes Lord Shafterbury's fyftem, that ridicule is the tert of truth, and that it is impoffible to ridicule with effeet what is intrinfically excellent. The warmeft admirers of Dr. Darwin's fplendid poem, and of the ingenious theories and ftated experiments of the notes, muft yet be amufed with fuch grotefque imitation of each; juft as they 
are diverted with the burlefque, in the Critic, of the death of Hotfpur, and of Eve's beautiful proteft to Adam,

Sweet is the breath of morn, \&c.

On the fubject of this fatire, Dr. Darwin wanted prefence of mind. Inftead of pretending, as he did, never to have feen or heard of the Loves of the Triangles, when queftioned on the fubject, he fhould voluntarily have mentioned that fatire every where, and praifed it's wit and ingenuity. He ought to have triumphed in a juft confcioufnefs, that his poem could lofe none of it's charms with the few, whofe praife is fame, by the artful refemblance of this falfe Florimel ; fecure that it's mock graces, brilliant as they are, would foon melt away, like the Nymph of Snow in the Fairie Queen, while the genuine charms of his mufe muft endure fo long as the Englifh language 
language fhall exift ; nay, fhould that perifh, Tranflation would preferve the Botanic Garden as one of its gems; if not in original brightnefs, would at leaft retain all that hoft of beauties which do not depend upon the perhaps intransfufable felicities of verbal expreffion. The lavifh magnificence of the imagery in this work, Genius alone, bold, original, creative, and fertile in the extreme, could have produced. It's profufion may cloy the faftidious, it's fplendor may dazzle the poetically weak of fight; but ftill it is the refult of that power, which Shakefpear characterifes when he fays,

The Poet's eye, in a fine phrenzy rolling,

Doth glance from heaven to earth, from earth to heaven, And as Imagination bodies forth The form of things unknown, the Poet's pen Turns them to thape, and gives to airy nothing A local habitation, and a name. 
SECOND CANTO

Opens with the charge of the Botanic Queen to her Gnomes, who are here reftored to that benevolent character allotted to them by Roficrufius, and which, to fuit his purpofe, Pope rendered malignant, in the Rape of the Lock. She addreffes them as miniftrant fpirits to fubterranean vegetation, and fpectators of all the aftronomic and terraqueous wonders of creation; of the Sun exploding our planet, the Earth, from his crater.

Except to introduce an extremely fine defcription of the fun's figns in the zodiac, it would be difficult to guefs why, the Gnomes fhould be fuppofed to have purfued the flying fphere, and encircled the year's ftarry girdle. Thofe fhould feem employments better fuited to the allotted nature of the Nymphs of Ignition, or at leaft of the Sylphs, than of thefe their fubter- 
fubterranean fifters. The epithet ardent, " your ardent troops," is a feldom-found inftance of inaccuracy in this poem, corrected and polifhed with fuch elaborate care; eager, active, any thing rather than an adjective metaphorically taken from fire, the affigned element of the nymphs recently difmiffed.

Next rifes the golden age, and Earth is inverted with Edenic privileges and exemptions. We are told, in a note, that there is an ancient gem, reprefenting Venus rifing out of the fea, fupported by two Tritons; that the allegory was originally an hieroglyphic picture, before letters -were invented, defcriptive of the formation of the earth from the ocean. The poet takes this opportunity of prefenting to his readers the moft beautiful portrait of Venus, firft emerging from her parent deep, that has been given by any Bard, ancient or modern; and it's features are unborrowed as they 
are peerlers. She has about her the traces of the humid element, from which the rifes, and they increafe her general lovelinefs and grace; wringing, with rofy fingers, her golden treffes, as they hang uncurled around her fair brows, while bright drops of water roll from her lifted arms, wander round her neck, ftand in pearls upon her polifhed fhoulders and back, and ftar with glittering brine her whole lucid form. Thus the Darwinian Venus,

O'er the fmooth furge, on filver fandals food, And look'd enchantment on the dazzled flood.

The firft terreftrial volcano is next defcribed; an earthquake of incalculable magnitude, producing continents and iflands on the before united and level earth, with feparating oceans rolling between them. The birth of the Moon is now reprefented as thrown from the Earth near

the 
the fouth-pole, in confequence of this primal convulfion, by the explofion of water, or other vapors of greater power. The lunar birth is thus beautifully prefented to the eye,

When rofe the continents, and funk the main, And Earth's huge fphere, exploding, burft in twain, Gnomes, how you gaz'd, when from her wounded fide, Where now the South-fea rolls its wafte of tide, Rofe, on fwift wheels, the Moon's refulgent car, Circling the folar orb, a fifter ftar; Dimpled with vales, with fhining hills embofs'd, And roll'd round Earth her airlefs realms of froft.

The difficulty of introducing thefe charming images, any other way than by reminding the Gnomes of what they are fuppofed to have feen, gives us, in this addrefs, the noun perfonal in apoftrophe, with a frequency which, far from being graceful, becomes almort ludicrous; as, "Gnomes, " how you gaz'd! \&c." - "Gnomes, " how you Thriek'd!" - " Gnomes 
"how you trembled!"- but infinite is the poetic fancy with which the hypothefis is maintained, of the earth being fruck from the crater of the fun, and the moon from the firft terreftrial volcano.

The Goddefs now reminds her fubterranean hand-maids of their affiftance in having formed into marble and other petrific fubftances, the diffolving Mells which covered the prominent parts of the earth, thrown up from her ocean in that firft convulfion, by fub-marine fires. Sculpture is here introduced, and poetic cafts of the famous ancient ftatues, the Hercules, Antinous, Apollo, and Venus, rife from the page. Roubilliac, unqueftionably the firft ftatuary of the modern world, is praifed with enthufiafm; and Mrs. Damer, the ingenious miftrefs of the chifel, with delight.

To the Gnomes is next imputed the power of extracting the faline particles 
from different kinds of earths; from proftrate woods, and from moraffes; and this introduces the defcription of a town in the immenfe falt-mines of Poland. With his peculiar ingenuity, this Bard of Fancy thows us the faline city; and that, and the ftatue fuppofed to be Lot's wife, the river and temple, gleam and fparkle on the imagination of every reader who has imagination. To thofe who have it not, the magnificent pageantries of this poem will pafs unreflected, unimpreffive,

And, like the bafelefs fabric of a vifion, Leave not a wreck behind.

Perfonification is furcly carried too far hen, in the next paffage, azotic gas is made the love of the virgin air, and fire. transformed into a jealous rival, indignant of the treacherous courthip. The trio are compared to Mars, Venus, and Vulcan, and the Homeric tale, of the enmerhed:

$$
\text { P4 pair, }
$$


pair, is told again. The mechanifm of the net; the ftruggles of the guilty goddefs to efcape; her impatient exhortations to her nymphs, to difunite the links of the iron net-work; her efforts to conceal her beauties from the furrounding deities, have all that truth to nature with which criticifm has juftly obferved, Shakefpear draws the manners of his imaginary beings. With much more of that appropriate verity has Darwin told this ftory than Homer, and not more voluptuoufly. This is the only paffage in the Botanic Garden which can juftly be taxed with - voluptuoufnefs, and with Homer its author thares the cenfure. Homer, whofe morality has been fo loudly, but fo partially applauded, fince his deities are all either libertine or unjuft; and of his heroes, only one is in himfelf a virtuous man, and he defends the caufe of his guilty brother, and does not once urge the reftoration of the ftolen wife to her in- 
jured hurband, an atonement not only in itfelf due, but which muft have raifed the fiege, faved the city, and fpared immenfe effufion of human blood. The ftory, if really founded, on hiftoric circumftances, might not have authorifed the reftoration of Helen, but it was in the poet's power to have made Hector urge it.

If the Homeric fable of Mars and Venus, in Vulcan's net, repeated by Darwin with new circumftances, more picturefque, not more indelicate, forms one fomewhat licentious paffage in the Botanic Garden, the Iliad contains feveral which are equally voluptuous, even after Pope has chaftened them. As to the amours of the Plants and Flowers, it is a burlefque upon morality to make them refponfible at its tribunal. The floral harems do not form an imaginary but a real fyftem, which philofophy has difcovered, and with which poetry fports. The impurity is in the imagination 
of the reader, not on the pages of the poet, when the Botanic Garden is confidered on the whole, as an immodeft compofition.

From the net of Vulcan, and the lovers it entangles, the Poet leads us to his forge, after the mention of iron, as produced by the decompofition of vegetable bodies. To perceive the ftrength and truth of the Forge-picture, no power of imagination, on the part of the reader, is neceffary; memory is fufficient. Who has not feen a blackfmith's thop, and heard its din? Here it blazes and refounds on the page. The formation of magnetic bars enfues, Though the power of the magnet has been known and applied to ufe from very early times, yet the Poet imputes thefe artificial magnets to their laft improver, the perfonal friend of his youth, Mr. Michell, mentioned early. in thefe memoirs. Of Mr. Michell's procefs in this improvement Dr. Darwin has formed another poetic defcription, 
defcription, fo diftinct that the operation may be performed from perufing it attentively.

And now we meet an animated aportrophe to Steel, praifing its ufe in navigation, agriculture, and war. This applaufive addrefs is one of the grandeft in the poem, where fo many are grand. What has poetry more noble than thefe firft fix lines of that eulogium?

Hail adamantine Steel! magnetic Lord,

King of the prow, the ploughnare, and the fword!

True to the pole, by thee the pilot guides

His fteady courfe amid the ftruggling tides !

Braves, with broad fail, th' immeafurable fea,

1 Cleaves the dark air, and aiks no ftar but thee!

A defcription of Gems fucceeds to that apoftrophe, as a work of the Gnomes, by whom, from marine acids mixed with the Thells of marine animals, and of calcareous, and argillaceous earths, they are here fuppofed 
pofed to be, from time to time, produced. Thefe natural transformations are comparatively illuftrated by thofe of Ovidian fable; and Proteus-gallantries are retold even more beautifully than Ovid has told them, particularly the ftory of Europa. It is here, beyond all poffible tranfendence, exquifite, and it clofes with a firited compliment to the natives of Europe.

Returning to the fubject, the Goddefs reminds her Gnomes of having feen the fubterranean volcanos forming the various fpecies of clay; from the porcelain of China, and of ancient Etruria, to thofe ufed in the beautiful productions of its modern namefake, brought to fo much perfection by the late Mr. Wedgewood. The mechanifm of the porcelain of China, with its ungraceful forms and gaudy ornaments, rifes on the page. The fuperiority, in the two laft circumftances, of our Englifn Etruria, is afferted, as producing " un-

" copied 
" copied beauty and ideal grace ;" and its mechanifm is alfo given, but in terms fo technical as to fpoil the harmony of the verfe in that paflage. Satire has caught hold of the feldom harhnefs, triumphantly difplaying it in the Loves of the Triangles. Mr. Wedgewood is addreffed as at once the friend of Art and Virtue. His medallion of the Negro-nave in chains, imploring mercy, is mentioned as reproaching our great national fin againft juftice and mercy, fo long refifting the admonitions of Benevolence and Piety, in the fenate; alfo another medallion of Hope, attended by Peace, and Art, and Labour. " It was made of clay from Botany Bay, " and many of them were fent thither, to " Thow the inhabitants what their materials "would do, and to encourage their in" duftry." The emblematic figures on the Portland Vafe, fo finely imitated in our new Etruria, next appear in all the charms 
of poetry, while the truth of their ingenious conftruction is fupported in the notes with wonderful learning and precifion, fo as to leave no doubt on the unprejudiced mind, that the Bard of Linneus has explained their real defign. This addrefs to Mr. Wedgewood clofes with the afferted immortality of his productions.

Coal, Jet, and Amber, are next imperfonized, an individual for the fpecies. The latter is placed on his " clectric throne," as a material, the natural properties of which were the fource of the difcoveries in electricity, and from which the name of that branch of modern fcience is derived, electron being the Greek word for amber. Led by its phofphoric light, Dr. Franklin comes forward in the act of difarming the lightning of its dire effects, by his electrical rods. His influence in procuring the freedom of America is applauded with much poetic imagery. The fhort-lived freedom 
of Ireland, in her acquirement of felf-legiflation, is allegorized by " the warrior $\mathrm{Li}$ " berty, helming his courfe to her thores." Another bold figure of Liberty fucceeds, prefented as a giant form, flumbering within the iron cage and marble walls of the French Baftile, unconfcious of his chains, till, touched by the patriot flame, he rends his flimfy bonds, lifts his coloffal form, and rears his hundred arms over his foes; calls to the good and brave of every country, with voice that echoes like the thunder of heaven, to the polar extremities;

Gives to the winds his banner broad unfurl'd, -And gathers in its thade the living world!

This fublime fally of a too-confidiag imagination has made the poet and his work countlefs foes. They triumph ovet him on a refult fo contrary; on the mortal wounds given by French crimes to real liberty. They forget, or choofe to forget, 
that this part of the poem (though publifhed after the other) appeared in 1791 , antecedent to the dire regicide, and to all thofe unprecedented fcenes of fanguinary cruelty inflicted on France by three of her republican tyrants, compared to whom the moft remorfelefs of her monarchs was mild and merciful.

The Botanic Queen now reminds her Gnomes of the means they had ufed to produce metallic fubftances; and, from the mention of filver and gold, the ftarts into a fpirited and noble exclamation over the cruelties committed by catholic fuperftition, in the Eaft and Wert Indies; and from them the turns, with equal indignation, to the Slave Trade, that plague-- pot on the reputation of our national humanity! that crying fin in the practice of our national religion! Greatly is it to the honor of our Englinh poets, within the laft twenty years, that, with very few exceptions, the 
beft and moft highly-gifted of them have fought their way to fame beneath the banners of Freedom and Mercy, whofe eternal nature no national or individual abufe, no hypocritical affumption, can change.

Thefe inftances of unchriftian barbarity lead to the ftory of the cruel and impious Cambyfes on his march to fubdue Ethiopia, after having deftroyed the temples and devafted the country of Thebes, and mafacred its inhabitants. The fate of that army is defcribed which he fent to plunder the temple of Jupiter, and which perifhed in the defert overwhelmed by fand. The Gnomes are confidered as minifters of that juft vengeance, and of the famine by which it was preceded; and this, by withholding the dews, and blafting regetation, and by fummoning the whirlwinds which caufe the fatal rife of the fand-tornados. The fucceffive horrors that overtook this army are depicted with the highert intereft and grandeur. 
grandeur. They rife in climax till the final overwhelming is thus brought to the thuddering imagination of the reader,

\section{- awhile the living hill}

Heav'd with convulfive throes,-and all was ftill!

language has nothing of more genuine fublimity.

Turning from this dread tragedy, the Botanic Queen affumes a lirelier ftrain, and compares her little minifters to the planets in an orrery. That beautiful machine is defcribed with it's fairy-mimicry of the ftellar evolutions. She exhorts her nymphs to the practice of feveral benevolent operations, guarding againft the mirchiefs of elementary excefs. Hannibal's renowned march over the Alps, againft tyrannic Rome, and the fuppofed means by which he facilitated his progrefs, are held up to their imitation. To this fucceeds an exhortation to feed the embryons, 
and forward the parturition of trees, plants, and flowers. For thofe offices a medical fimile occurs, and afterwards a fcripture ftory is told, Peter releafed from prifon by an angel, and to that angel the illuftrioufly benevolent Howard is compared.

Imputed affiftance, on the part of thefe fubterranean nymphs, in the chemical. decompofition of animal and regetable fubftances, introduces the ancient fable of the flaughtered, buried, and affurgent Adonis. His ftory is told with not lefs added poetic excellence than, with accerfion of perfonal beauty, he is faid to have arifen from the dark manfions of Proferpine, and to have returned to Venus. Dr. Darwin's reafons, given in the note to this paffage, for rejecting former interpretations of that allegory, are convincing; and his fubftituted folution is not only highly ingenious, but deeply philofophic; and good fenfe fanctions the conjecture. 
This fable clofes the addrefs of the Goddefs to her Gnomes. Their elfin flight on their appointed errands, is defcribed with playful elegance, and compared to the fucceffive fhadows that pars over a funny vale beneath the light clouds. With that comparifon the fecond Canto terminates. If the Gnomes make their exit with lefs poetic fplendor than their predeceffors, it muft be confidered that the Nymphs of Fire are perfonages of more intrinfic dignity.

\section{THE THIRD CANTO}

Opens with a charge to the Water Nymphs, and we are told that the Godders gives it in tones fo fweet and fonorous as to Mhake the wrinkling fountains, curl the deep wells, rimple the lakes, and thrill the rivers.

The three firft words felected to exprefs the different kind of actual vibration on the

- fountains, 
fountains, wells, and lakes, are inftances of that nice difcrimination which imparts fo much vitality to verfe, and gives back to the reader his faded recollection of the objects of nature in their comparative diftinctions. Though he may have viewed them often with unexamining eyes, yet no fooner do they arife before him on the poetic page than he recognifes their truth with the thrill of delight; for who that looks into the records of the Mufes, however infenfible to the creations of Fancy, can view without pleafure the faithfully reflected image of nature in the fubtle variety of her lineaments.

Thick as the dews which deck the morning flowers, Or rain-drops twinkling in the fun-bright thowers, Fair nymphs, emerging in pellucid bands, Rile, as the turns, and whiten all the lands.

Their miftrefs tells them alfo, how much the is confcious of their power and $u f e$, in the formation, fuftenance, and protection of Q3 
the vegetable world. In the exordium of this charge we meet a couplet rivalling in picturefque beauty the lines -in Collins' charming, though rhymelefs Ode to Evening, when he tells the grey-ftoled perfonage, that, from his hut on the mountain fide, he loves to contemplate, in a howery, twilight,

The hamlets brown, and dim-difcover'd fpires, And hear their fimple bells, and mark o'er all

Her dewy fingers draw The gradual, dufky veil.

The Botanic Queen fays to her aqueous miniftry in thefe rival lines,

Your lucid hands condenfe, with fingers chill,

The blue mirt hovering round the gelid hill.

This charge has one harfh line; thus, And as below the braids her hyaline hair. -

The employment gentle, the attitude graceful, that harfhnefs of meafure which 
is often fkilful when ufed to exprefs violent exertion, is here cenfurable.

Thefe new vicegerents are praifed as feeding the harveft, filling the wide-ribbed arch with hurrying torrents, to affift the operation of the mill and the progrefs of the barge, and leading the refluent water to it's parent main. Thefe operations on the water induce a fimile for the progreffive and returning courfe of the blood. The purpureal tint it gives to the fair complexion of youthful beauty; the warm glow to her hair, the laugh of health to her lip, and it's lightning to her eyes, form a lovely picture in this fimile; and it clofes with a medical obfervation in a fine poetic figure.

Juft difcernment will not ceafe to admire the facile fuccefs and artful grace with which this Poet fubdues the difficulty of rendering all forts of fcience fubfervient to the purpofes of high heroic verfe; or to abferve how feldom even the moft 
technical terms diminifh the harmony of his meafure, or the elegance of his imagery.

Mighty fway is attributed to the aqueous ladies over thofe realms of fcale and Thell, which are covered by the fea; and they are confidered as architects of the pearly palaces of the firh. The modern experiment of fmoothing rough waves with oil, is confidered as their fuggeftion; alfo various fub-marine and benevolent influences. To them the birth of rivers, from the Alpine fnows. The Danube, the Rhine, and the Tiber, are mentioned; the laft as flowing through his degenerate realms with diminifhed waters. The features of that degeneracy are marked; the race of patriots, heros, and legiflators, long fince become fingers, dancers, and monks; and the paffage concludes with this fublime picture of the prefent ftate of that longrenowned river:

Parts with chill ftream, the dim religious bower, Time-moulder'd baftion, and difmantled tower; 
By alter'd fanes, and namelefs villas glides, And claffic domes, that tremble on his fides; Sighs o'er each broken urn and yawning tomb, And mourns the fall of Liberty and Rome.

Rivers being the fubject, the Nile and it's annual overflow, gives rife to grand allegoric imagery, and to nobly-imagined fcenes. That overflow is afcribed to the monfoon winds, which deluge Nubia and Abyffinia with rain.

Sailing in air, when dark Monfoon en hrouds

His tropic mountains in a night of clouds;

Or, drawn by whirlwinds, from the Line returns, And Mowers on Afric all his thoufand urns; High o'er his head the beams of Sirius glow; And, dog of Nile, Anubis, barks below. Nymphs, you from cliff to cliff attendant guide, In headlong cataracts, the impetuous tide; Or lead o'er waftes of Abyffinian fands The bright expanfe to Egypt's fhowerlefs lands.

Her towns, her temples, and fultry plains are contrafted with a fublime defcription of Hecla and his burning mountain. It's column of boiling water is transformed into 
a malignant Sorcerefs, whofe baleful fpells had been broken by the power of theré benevolent Naiads.

The hypothefis, that warm falubrious fprings are produced by fteam arifing from water falling on fubterranean fires, and that this fteam is condenfed between the ftrata of incumbent mountains, and collected into fprings, occafions a fportive addrefs to Buxton. It is fucceeded by an elegant compliment to the Duchefs of Devonfhire, leading a train of Graces from Chatfworth to that tepid fountain. From the epithet fairy given to legions, we fhould fuppofe thefe Graces a part of the machinery of the Poet; but, as the paffage proceeds, it defcribes beautiful young women bathing with fuch exquifite precifion, that the fcene of action confidered, it becomes impoffible to contemplate them as ideal perfonages, efpecially as the laft couplet is utterly at war with acrial fubitance; thus, 
Round each fair Nymph her dropping mantle clings, And Loves emerging thake their fhowery wings.

The Loves, which are indifputably machinery, confufe the picture, if the Nymphs alfo are of that fpecies. The expreffion, fairy legions, is to be regretted; it renders the lively and lovely defcription amenable to Dr. Johnfon's cenfure of a paffage in one of our poets, " that it is metaphoric " in one point of view, and literal in " another."

The Duke of Devonfhire's public fpirit and architectural tafte, next become the theme, and they involve a charming picture of the Crefcent, that gem of Grecian -art in Britain; and of the new plantations which furround it. Derbyrhire ftone has an amber tint, and hence the Buxton Crefcent rifes a golden palace in the defert.

The Goddefs next congratulates her Water Nymphs on having celebrated the odd 
odd nuptials of pure Air and inflammable Gas. We had heard of their courthip earlier in the poem. That courthip, and this their marriage, forms one of the wildeft extravagances of the work; but the Homeric fable, which illuftrates the airy bride and groom, is charming in the firft degree. Juno, attired by Venus, to captivate Jove. With the moft luxuriant fancy, and with new circumftances, this little drama rifes again on the Darwinian page. It will not lofe, but gain in a juft eftimation of poetic merit, by comparifon with the tranflations, by Cowper and Pope, of this celebrated part of the Greek Poet's machinery. Let them be compared, and firft Cowper's literal tranflation, firft edition.

\section{— Firft, the lav'd all o'er}

Her beauteous body with ambrofial lymph;

Then polifh'd it with richeft oil divine,

Of boundlers fragrance. Oil, that in the courts

Eternal only fhaken through the Akies 
Breath'd odours, and through all the diftant earth * Her whole fair body with thefe fweets bedew'd, She pafs'd the comb through her ambrofial hair, And braided her light locks ftreaming profufe

From her immortal brows; with golden ftuds She made her gorgeous mantle faft before; Etherial texture, labour of the hands Of Pallas, beautified with various arts, And brac'd it with a zone, fring'd all around An hundred fold; her pendants, triple gemm'd, Luminous, graceful in her ears the hung $t$. And covering all her glories with a veil Sun-bright, new woven, bound to her fair feet Her fandals elegant. Thus full attir'd In all her ornaments, the iffued forth, And beck'ning Venus from the other powe Of Heav'n apart, the Goddefs thus befpake.

\section{Pope's tranflation of the fame paffage.}

Here firft the bathes, and round her body pours Soft oils of fragrance, and ambrofial thowers. The winds perfum'd, the balmy, gale convey Through heav'n, through earth, and all th' aerial way. Spirit divine! whofe exhalation greets The fenfe of Gods with more than mortal fweets. 
Thus, while fhe breath'd of heav'n, with decent pride Her artful hands the radiant treffes tied;

Part o'er her head in thining ringlets roll'd,

Part o'er her fhoulders wav'd like melted.gold;

Around her neck a heavenly mantle flow'd

That rich with Pallas' labour'd colours glaw'd;

Large clafps of gold the foldings gather'd round;

A golden zone her fwelling bofom hound;

Far-beaming pendants tremble in her car,

Each gem illumin'd with a triple ftar;

Then o'er her head the cafts a veil more white

Than new fall'n fnow, and dazzling as the light;

Laft, her fair feet celeftial fandals grace.

Thus iffuing radiant, with majeftic pace,

Forth from the dome th' imperial Goddefs moves, And calls the mother of the Smiles and Loves.

Pope has hown better tafte in female drefs than his mafter. A zone with an hundred folds of fringe upon it, muft be a very heavy and inelegant ornament. The zone of plain gold, fubftituted by the rhyme tranflator, is grander and more graceful as well as more fimple.

Darwin, who gives this fable after his own manner, tells us, that Venus not only 
lent the ceftus, but attired the Goddefs herfelf ; and paffing over the claffic ceremony of the bath, and the operation of the oils, which perhaps he thought too Hottentotin, he defcribes more concifely, yet not lefs brilliantly, this magnificent labour of the toilette; thus,

So, rob'd by Beauty's Queen, with fofter charms,

Saturnia woo'd the Thunderer to her arms;

O'er her fair limbs a veil of light the fpread,

And bound a ftarry diadem on her head;

Long braids of pearls her golden treffes grac'd,

And the charm'd ceftus fparkled round her waift.

The ceftus is here a vifible and brilliant ornament, inftead of being, as Homer afterwards tells us, hid in Juno's bofom. Pope, in a note to this paffage, obferves, that, by this difpofal, the Poet meant to convey an idea of the matron-like modefty of Juno, who conceals what is to render her engaging; while Venus, wearing the ceftus in open fight, oftentatioufly difplays the means by which the captivates: but 
this fort of leffer morality belonged not to the times in which Homer lived; neither is peculiar delicacy at all characteriftic of the Juno he has drawn. His more probable reafon for making her hide this ornamental fpell, was the danger that Jupiter, if he faw the borrowed zone, fo often feen on the perfon of his daughter, would know it, and, confcious of it's power to excite paffion, would have been aware of the defign of his wife, and either not allowed of the interview, or difarmed the girdle of it's magic. Supreme wifdom muft have foiled difcovered art. Neither of thefe fuppofitions occurred to Dr. Darwin, or perhaps his Juno alfo had hidden her gay talifman.

Homer exprefsly fays, Juno did not take her chariot on this conjugal vifit; but Darwin allots her that mode of conveyance, and the change enabled him to affign to the Emprefs of Heaven her due pomp and Itately 
fately retinue. Upon this imperial and celeftial equipage the modern poet has lavifhed all the fplendors of his imagination. Cupid is the chariotecr, and Zephyr flies before, flowering rofes from his wings; Naiads and Dryads, Fawns and Wood-Boys are in the train. The reader is empowered, by diftinctners of poetic defcription, to purfue the chariot with his eye, as it afcends the fteeps of Ida, now loft in it's thick woods, now in full blaze, winding around it's rocks.

But furely there is an error of judgment in making Cupid wing an arrow to the breaft of Jove, as the retinue approaches, fince that mode of awakening the paffions of Jupiter for his queen, renders the charmed ceftus a fuperfluous gift. And again, this gay car is reprefented as drawn by doves; from which it thould feem that Venus had lent her equipage, as well as her girdle, on that occafion. 
The addrefs of the God to his Goddefs is incomparably more elegant in the verfe of Darwin than in the tranflation of Cowper, or even of Pope. Thus fays Cowper, with all that cramp literality which hobbles through his verfion.

Soon he accofted her, and thus inquir'd:

" Juno, what region feeking, haft thou left

" Th' Olympian fummit, and haft here arriv'd

“With neither fteeds nor chariot in thy train ?"

\section{POPE.}

Fix'd on her eyes he fed his eager look, Then prefs'd her hand, and thus tranfported fpoke:

" Why comes my Goddefs from th' etherial 1 $\mathrm{ky}$, "And not her fteeds, and flaming chariot nigh ?"

\section{DARWIN.}

Pierc'd on his throne, the farting Thund'rer turns, Melts with foft fighs, with kindling rapture burns;

Clafps her fair hand, and eyes, in fond amaze, The bright Intruder with enamour'd gaze :

"And leaves my Godders, like a blooming bride, "The fanes of Argos, for the rocks of Ide ;

" Her gorgeous palaces, and amaranth bowers, "For cliff-top'd mountains, and aerial towers?" 
But to refume the Botanic Goddefs and her enumeration of the interefting employments of her third clafs of Nymphs; their difpofal of all thofe bright waters which make Britain irriguous, verdant, and fertile. We find this beautiful couplet in the courfe of the paffage:

You, with nice ear, in tiptoe trains pervade Dim walks of morn*, or evening's filent thade.

She then places them on the fhore, liftening to it's paufing murmurs, and to the fong of the Nereid, as on her playful fea-horfe the glides over the twilight-main. A nother exquifite picture arifes, profeffedly from an antique gem. Great fkill is thown in varying the attitude, appearance, and employments of this beautiful Sea-Nymph, on her voyage, from thofe of Europa, croffing the fea on her bull, in the preced-

* What exquifite pieture! 
ing Canto. Her's is a day, and this is a night voyage. Europa draws up her feet beneath her robe, fearful of touching the water ; the fecure Nereid drops them carelefsly down. Europa clings timidly round the neck of her Taurus, and refts her cheek upon the curls of his forehead, while her mantle floats unheeded on the breeze. The Nereid has no apprehenfion; the and her fteed are both in their element. She gives him the rein, lifts her eyes to the evening ftar, and fings the birth of Venus. She reftrains her arching veil, with her hands, from floating on the gales of night, while the mantle of, Europa was abandoned to the day-breeze. The Nereid is without fear, and therefore attends to the prefervation of her drefs; Europa is fomewhat frightened, and therefore pays no attention to hers. Thefe differences, however apparently, are not really trivial. The mcre verfifier knows not how to create them.

The 
The Poet knows their importance; how much they will infpirit his portraits, and diftinguin them from each other. In the progrefs of this epifode the Nereid loofes her veil (we may conclude the wind had fallen) and we meet the following defcription of a very graceful operation, that of a lovely female combing her lavinh treffes:

O'er her fair brow her pearly comb unfurls Her beryl locks, and parts the waving curls;

Each tangled braid, with glift'ning teeth unbinds, And with the floating treafure mufks the winds.

This is not a repetition of the employment of the new-born Venus, in the fecond Canto. She had recently emerged, and therefore her hair muft neceffarily hang uncurled, and the is in the attitude of wringing the water from her golden treffes; than which no pofition can be more favourable to female fymmetry.

Doctor Darwin's poem paints every attitude and employment which, in either 
fex, can be rendered elegant. No autho: ever had a mind more keenly awakened to grace in all its varieties, or could more exquifitely paint it.

That perception, and that talent, the, in his clafs of compofition, peerlefs Richardfon poffeffed in an equal degree. No profewriter ever was, or perhaps ever will be, fo great a painter; and to that power what a conftellation of other endowments contributed to immortalize the pages of Clariffa and Grandifon! Novels no longer, but Englifh Claffics, tranflated into every European language, and in all foreign countries confidered as fome of the nobleft efforts of Brition Genius, .

But the Darwinian Nereid has been left a little before her time; other circumftances attend her, too poetic to remain unnoticed. Her fong " thrills the waves;" and the Shadowy Forms of Night gleam on the margin of the Phore, "with pointed 
" ears," to denote the act of liftening. Perhaps that characteriftic had been better omitted, fince it belongs to brute, not to human animals, and is at war with the imaginary grace of thefe twilight forms. The Moon paufes, and the Stars thoot from their fpheres to liften. That laft circumPtance is evidently from Shakefpear's allegory in The Midfummer Night's Dream, alluding to the confpiracies formed in favor of the imprifoned Queen of Scotland, by the Duke of Norfolk, and other noblemen of the court of Elizabeth. This is the allegory:

I faw a Mermaid on a Dolphin's.back Uttering fuch dulcet and harmonious founds, That the rude fea grew civil at her fong, And certain ftars thot madly from their Spheres, To hear the Sea-Maid's mufic.

That he might guard againit the difpleafure of Elizabeth for this fally, it is immediately followed by as high an allegoric compliment paid to herfelf. 
On the Poet's difmiffal of the Nereid, the death of Mrs. French of Derby, is introduced as a fubject of forrow to the Water-Nymphs of its river. This picture of Milcena is very lovely, ftraying with her infants on the banks of the Derwent, and pondering, with fcientific eye, the infects and plants on the fhores of that ftream. There is a tender ftrain of morality in this paffage ; but the annexed epitaph on Mrs. French, however beautiful as poetry, is by no means fit for it's originally purpofed fituation, a tombftone in the great church at Derby. The author of thefe memoirs is ignorant whether, or not, it is there infcribed. "Clouds of filver, and Beauty " pleading for her hufband's errors at the " throne of God," may form a very poetical, but it is a very heathenim refurrection. The mention of Brindley, the Father of commercial Canals, has propriety as well as happinefs, Similitude for their courfe, 
to the finuous track of a ferpent, produces a fine picture of a gliding animal of that fpecies, and it is fucceeded by thefe fupremely happy lines:

So, with ftrong arm, immortal Brindley leads

His long canals, and parts the velvet meads;

Winding in lucid lines, the watery mars

Mines the firm rock, or loads the deep morafs ;

With rifing locks a thoufand hills alarms,

Flings o'er a thoufand ftreams it's filver arms;

Feeds the long vale, the nodding woodland laves,

And Plenty, Arts, and Commerce, freight the waves.

Nymphs; who erewhile on Brindley's early bier,

On fnow-white bofoms fhower'd th' inceffant tear, Adorn his tomb!-Oh, raife the marble burt, Proclaim his honors, and protect his duft ! With urns inverted, round the facred fhrine Their ozier wreaths let weeping Naiads twine, While on the top mechanic Genius ftands, Counts the fleet waves, and balances the fands!

There is a note to this paflage, which urges the duty of erecting a monument to Brindley in Lichfield Cathedral. Certainly it would be to the credit of thofe who fhould 
Thould fubfcribe to raife it, fince the county of Stafford has been fo materially benefited by his fuccersful plans; but in the above eulogium, Dr. Darwin has given him a more enduring memorial than ftone or marble could beftow.

The mechanifm of the pump is next defcribed with curious ingenuity. Common as is the machine, it is not unworthy of a place in this fplendid compofition, as bcing, after the finking of wells, the earlieft of thofe inventions, which, in fituations of exterior aridnefs, gave ready acceffion to water. This familiar object is illuftrated by a picture of Maternal Beauty adminiftering fuftenance to her Infant. To that fucceeds an energetic reproof, and pathetic admonition to mothers in affluent life, whom indolence, or diffipation, feduces to the unnatural negled of that delightful duty. For an infant numbering on the maternal bofom which has nourifhed him, 
there is the following allegoric fimile, of no common elegance :

Thus, charm'd to fweet repofe, when twilight hours Shed their foft influence on celeftial bowers, The cherub, Innocence, with fmile divine, Shuts his white wings, and neeps on Beauty's Mrine.

The Ode to Morning, in Elfrida, contains a nearly refembling image; thus:

Away, ye Elves, away,

Shrink at ambrofial morning's living ray!

That living ray, whofe power benign

Unfolds this fcene of glory to our eye,

Where, thron'd in artlefs majefty,

The cherub Beauty fits on Nature's ruftic thrine.

Probably to the involuntary plagiarifn. of forgotten impreffion, we owe this fifterpicture on the page of Dr. Darwin.

The ufe of water by the fire-engine next occurs. Poetry has nothing more fublime than this, the preceding picture of a Town on Fire :

From dome to dome when flames infuriate climb, Sweep the long ftreet, inveft the tower fublime; 
Gild the tall vanes amid th' aftonin'd night, And reddening heaven returns the fanguine light; While, with vaft ftrides and briftling hair, aloof Pale Danger glides along the falling roof; And giant Terror, howling in amaze, Moves his dark limbs acrofs the lurid blaze; Nymphs, you firft taught the gelid waves to rife, Hurl'd in refplendent arches to the fkies;

In iron cells condens'd the airy fpring; And imp'd the torrent with unfailing wing; On the fierce flame the fhower impetuous falls, And fudden darknefs fhrouds the Thatterd walls; Steam, fmoke, and duft, in blended volumes roll, And Night and Silence repoffers the pole.

Dryden, in his Annus Mirabilis, has defcribed the great fire in London. Some very fine lines occur in that defcription, but it is prolix and feeble in comparifor with the above.

The melancholy circumftances of the Woodmafon family, and that of Lady Molefworth, each of whom fuffered dreadfully by fire, are next pourtrayed with much pathetic folemnity, and the Water-

Nymphs 
Nymphs are reproached for not having prevented thofe evils.

After this mournful little drama, the Botanic Queen allots new tafks to thefe her hand-maids in the care of vegetation, and they are beautifully fpecified. To them fucceeds an highly interefting picture of Sympathy in a female form, bending over a rock to affift the fhip-wrecked mariners; the is thown afterwards as fupporting feeble Age on her arm, pouring balm into the wounds of Sorrow; fnatching the dagger from Defpair; lulling Envy to fleep, and while the repofes, ftealing her envenomed arrows from her quiver. An animated eulogium on a benevolent young lady of Ireland, diverfifies thefe commiffions; alfo three of Hercules labors. A flooded country is prefented in the deluged Etolia; and the Water Fiend, who caufed the inundation, and whom Hercules fubdues a fecond time, when affuming the 
form of a fnake, it attempts to efcape from the hero. It is thus admirably pictured:

Then to a fnake the finny Demon turn'd, His lengthen'd form, with fcales of filver burn'd;

Lafh'd, with refiflefs fweep, his dragon-train, And thot meandering o'er th' affrigbted plain.

Perhaps the defcription of the Fiend's next transformation into a Bull, is not eminently judicious; the terms "filver " hoofs," and "flowery meadows," which might well have fuited the gentle bull of Europa, are too nice and gay to harmonize well with the enraged monfter, one of whofe horns was torn off by Hercules. Of the habits and manners of that formidable Brute, when incenfed, a very inferior Poet, lately deceafed, has given a more impreffive picture. We fometimes find one or two good paffages in the writings of ordinary verfifiers. Sternhold's and Hopkins' nonfenfical and vulgar tranflation of the Pfalms, contain eight lines which Pope profeffed 
profeffed to envy. Though Hurdis was chofen Profeffor of Poetry in Oxford contrary to Pope's precept,

Let fuch teach others who themfelves excel,

yet he has given a defcription of the only very terrific Englin animal, which, when weeded of a long interrupting digreffion in the middle of it, about a thunder-ftorm, forms the moft natural portrait of a malicious Bull that can perhaps be found in any of our poets; thus,

\section{-Tis pleafure to approach,}

And, by the ftrong fence fhielded, view fecure

Thy terrors, Nature, in the favage Bull.

Soon as he marks me, be the tyrant fierce,

To earth defcends his head; hard breathe his lungs

Upon the dufty fod. - A fulky leer

Gives double horror to the frowning curls

That wrap his forehead; and ere long is heard,

From the deep cavern of his lordly throat,

The growl infufferable. *-Tramples then

- Here comes in the impertinent thunder ftorm. 
The furly Brate, impatient of difdain, And fpurns the foil with irritated hoof; Himfelf inhaler of the dufty fod;

- Himfelf infulted by the pebbly thower, Which his vain fury raifes. Nothing fear'd, Let him, incens'd, from agitated lungs Blow his thrill trump acute till echo ring, And, with a leer of malice, fteal away, Affault and vengeance fwearing ere be long !

The Iart command of the Botanic Goddefs to her Water-Nymphs, enforces their duties to plants and flowers; to render the vales irriguous, and to feed with their rills the floral and herbaceous roots. To the courfe of this moift nutriment through the vegetable fibres, is compared that of the chyle through the human frame; and to that, another fimile fucceeds. As the firft is fcientific, fo is the fecond picturefque; it is a Turkin pilgrimage to Mecca, confifting of various caravans on their road over the fultry and fandy defert, and meeting with a pure rill, which, defcending from diftant rocks, had taken it's courfe through 
through the wafte plain. The parched Travellers alight, kneel on the brink in grateful joy, and, bending over it, affuage their thirf. This rill fomewhat fuddenly becomes a lake, and reflects the eager and delighted multitude. With this little fcene the commiffionsto the $\mathrm{W}$ ater- $\mathrm{Nymphs}$ conclude, and their obedient flight is fcarcely lefs poetically featured than that of the Nymphs of Fire. The fimilies, which illuftrate the flight of the aqueous minifters, are the cvolutions of the waterfpider, and the exercife of fkaiting amongtt the natives of northern climates, The laft is thus admirably defcribed:

Sn where the North congeals his watry mafs, Piles high his fnows, and floors his feas with glafs, While many a month, unknown to warmer rays, Marks it's now chronicle by lunar days;

Stout youths and ruddy maids, a fportive train, Leave the white foil and ruth upon the main. From ifle to ine the moon-bright fquadrons ftray, And win, in graceful curves, their ealy way; 
On ftep alternate borne, with balance nice

Hang o'er the gliding fteel, and hifs along the ice.

EOURTH AND LAST CANTO OF THE ECONOMY OF VEGETATION,

Confirts of a charge to the Sylphs, as benevolent fpirits, to protect the vegetable fubftances, after they had emerged to light and air; to defend them from all the malignant operations of nature, and to cherifh and affift the influence they may receive from all her vital and benign powers.

The deadly and falubrious winds; the volcanic and peftilential airs; the Tornado, dreadful to mariners, \&c. ; every thing here has animal life and confcioufnefs. It was the author's plan, and he could not, at leaft in his own idea, depart from it with propriety. Hence, the Sylphs alfo are reminded of having prefided at the nuptials of the pureft of the Airs with Light. The paffage which ufhers in this whimfical marriage, 
marriage, is very beautiful, the expreffion, “ fimpering lips," excepted; but it was difficult to find variety of terms equally happy where the effect of pleafurable fenfations on the countenance muft fo often be defcribed. From thefe aerial nuptials vital fpirit is fuppored to proceed, which pervades and animates all nature. The loves and marriage of Cupid and Pfyche are prefented, poetically pictured from the well-known gems. This life-infufing air is contrafted with the Syroc of Italy, and the Simoon of the African defert. The laft is prefented as a Demon. Univerfal perfonification was the order of the Mufe in this work, not to be infringed; elfe, when circumftances are in themfelves fublime (and moit things terrible in nature become fublime in poetry), they are more likely to be of diminithed than increafed force, by the addition of fabled endowment. A comparifon between the Simoon defcribed 
defcribed literally by Southey, in his Joan of Arc, and figuratively by Darwin, will perhaps evince the truth of this obfervation.

The Botanic Gueen fays to her Sylphs,

Arreft Simoon amid his wafte of fand, The poifon'd javlin balanc'd in his hand !

Fierce on blue ftreams he rides the tainted air,

Points his keen eye, and waves his whifling hair;

While, as he turns, the undulating foil

Rolls it's red waves, and billowy deferts boil.

This is a fine picture of the Demon ot Peftilence. The fpeed of his approach is marked by the ftrong current of air in which he paffed, and by the term rohifling annexed to his hair. The winds have hitherto, almoft exclufively, poffeffed that term. Here transferred to the lifted hair of the Demon, it increafes the terrific power of his approach. But let the Simoon be viewed where it's terrible graces are native, 
and no attempt made to heighten them by allegory.

JOAN OF ARC, IOth BOoK.

- Ominous fear

Seizes the traveller o'er the tracklefs fands,

Who marks the dread Simoon acrofs the wafte Sweep it's fwift peftilence. To earth he falls,

Nor dares give utterance to the inward prayer,

Deeming the Genius of the defert breathes

The purple blaft of Death.

We are informed by travellers, that to inhale the leaft portion of this mephitic blaft is fatal. They therefore fall on their faces, and hold their breath till it has paffed over them.

But the Darwinian perfonification of the Tornado fublimely heightens the horror of that watry pert. It fucceeds that of the Simoon; and the Fog, invefted with animality, forms an immediate and friking contraft to the preceding monfters. It is drawn with fuch fingular felicity of 
imagination that there is no refifting the defire of quoting the paffage here:

Sylphs, with light thafts, you pierce the drowfy Fog, That lingering numbers on the fedge-wove bog, And with webb'd feet o'er midnight meadows creeps, Or flings his hairy limbs o'er ftagnant deeps.

The benevolent little fpirits are then exhorted to combat Contagion, ftealing from charnel-vaults to bring death to the people. The plague, which in $16_{3} 6$ raged in Holland, is here introduced, with a beautiful ftory of faithful Love prevailing over the defire of felf-prefervation. A young maid is firft feized in a, till then, uninfected family. This admirable line denotes the dread of it's other individuals to approach, affift, or comfort her,

And ftarting Friendhip Thunn'd her as the pafs'd.

Perceiving herfelf deferted, and fearing to fpread the infection amongft thofe the loved, the feeks the garden, determined to die 
die there. Her betrothed lover hears of her fituation, and purfues her thither; raifes a tent; procures her food, covering, and medicines; binds her fevered brows, and ftrews aromatic herbs and flowers upon her pillow. He efcapes the contagion himfelf, and reftores his beloved miftrefs to health. The Poet has very fweetly told this interefting tale; a fingle epithet is perhaps the only word it contains which could be altered to advantage. It is in the following line,

And clafp'd the bright infection in his arms.

The adjective bright is too gay for it's fituation; fair, or lov'd, would be more fubdued, and in better keeping with the mournful tendernefs of the narration.

Lefs bold, fays the Poet, was Leander, eying, as he fwam, the love-lighted tower. Lefs bold alfo, Tobias, inftructed by an angel to drive away the demon from the fatal bride. 
The Sylphs are now applauded by their Queen for having inftructed Torricelli and Boyle, concerning the properties of air, it's preffure and elafticity. The operations of the weather-glafs and air-pump are defcribed with philofophic accuracy and poetic elegance. Young Roffiere's dire fate, precipitated from his flaming montgolfier, comes forward here, and is pictured with great poetic ftrength; nor is the illuftration of that lamentable event, by the fable of Icarus, lefs happy in it's novel and mournful graces; his faithlefs and fcattered plumage dancing on the wave; the Mermaids decking his watry tomb, ftrewing over his corfe the pearly fea-flowers, and ftriking, in the coral towers, the paufing bell, which echos through the caves of Ocean! Surely it is not poffible to admire too fondly the beautiful and exhauflefs varieties of this darling Bard of Fancy.

Critics have afferted, that the poetic mind 
mind has little efflorefcence after middle life; that, however the judgment may ftrengthen, the vivid luxuriance of the imagination abates. Milton's Paradife Loft, Darwin's Botanic Garden, and Cowper's Ta1k, each began after life had many years declined from it's meridian, confute the dogma. Dr. Johnfon has combated it's fallacy, and with more truth obferved, that fo long as the underftanding retains it's ftrength, the fancy, from time to time, acquires added vigor and new ftores of imagery. Nor does the extreme poetic inferiority of the Paradife Regained to the Paradife Loft, at all difprove the converfe propofition. We are to look for that inferiority in the fo much more reftraining nature of the fubject, for poetry, above all others, improper. Poetry! to whofe very exiftence, if it is to deferve it's name, an infinitely larger portion of inventive and figurative ornament is neceffary than the hallowed 
hallowed fobriety of the New Teftament and it's myfteries, can admit without the moft revolting impropriety. It's choice, as the theme of an Epic Poem, was a radical error, which neceffarily involved thofe long trains of comparative profaicifm, over which we yawn, however fometimes awakened by noble paffages to recognife ftrength, which, though feldom put forth, we feel to be undiminifhed; to difcern fome rays of light which, amidft their infrequency, we yet perceive to be unfaded.

Frefh commendation is next given to the Sylphs for their infpirations in the mind of Dr. Prieftley, concerning his analyfis of the atmofphere. The paffage is moft poetic, although purely chemical. Air calcining the phlogiftic ores is termed the marriage of Ether with the Mine. Thefe nuptials are illuftrated by the retold ftory of Pluto and Proferpinc. There is much propriety in this illuftration, fince Lord Bacon has 
explained that fable as an hieroglyphic allufion, to fignify " the combination, or " marriage of etherial fpirit with earthly " materials."

A whimfical poffibility is next fuppofed: that Dr. Prieftley's difcoveries will hereafter enable adventurers to travel beneath the ocean in large inverted thips and diving balloons. A note to this paffage afferts, that the experiment was fuccefsfully made by a Frenchman in the reign of James the Firft, and it ftates the particulars. A fplendid fub-marine voyage next occurs. It is to the warm tropic feas and fhadowy ice-inles of the polar regions, and to be performed by Britannia. Her tears are to flow as the paffes over the fad and vifible remains of hip-wrecked lovers, mercantile and fcientific adventurers, particularly thofe of Day and Spalding, who each perifhed in their diving-bells. Here the deplored fate of 
of Captain Pierce, his family and fellowvoyagers, thus forms a tragic drama:

Oft o'er thy lovely daughters, haplef's Pierce!

Her fighs thall breathe, her forrows dew their hearfe. With brow upturn'd to heav'n, "We will not part," He cried, and clafp'd them to his aching heart.

Dafh'd in dread conflict on the rocky grounds,

Craft the fhock'd mafts, the ftaggering wreck rebounds; Through gaping feams the rufhing deluge fwims;

Chills their pale bofoms, bathes their huddering limbs ; Climbs their white fhoulders, buoys their ftreaming hair, And the laft fea-thriek bellows in the air.

Each, with loud fobs, their tender fire carefs'd, And gafping, ftrain'd him clofer to her breaft. Stretch'd on one bier they neep beneath the brine, And their white bones with ivory arms entwine.

The third, fourth, and fifth, couplets of the above quotation, are extremely fine pictures, and "found never echoed fenfe" with more folemn horror than " and the " laft fea-fhriek bellowed in the air." The defcription ought to have clofed with that line, and the next couplet fhould have immediately 
mediately followed the paternal exclamation. Beyond the utmoft power of the pencil do the fix grand verfes of this paffage image death by thipwreck; but the " white bones and " ivory arms" of the concluding line, are every way exceptionable. They difturb the awful impreffion made on the mind by the laft fea-nhriek. Aiming to be pathetic they are in reality ludicrous, the ivory arms of bones! The bones of ivory arms we might underftand, though it would be affected expreffion, but the converfe terms feem nonfenfe. One of the firf of our exifting poets, Mr. Crowe, public orator at Oxford, whofe compofitions, by their genuine excellence, atone for their too limited quantity, has told this fad ftory with folemn and fimple beauty in his Lewefdon Hill, one of the nobleft local poems in our language. In his narration we find nothing which can ftrictly be termed picturefque, though the four introductory lines 
are highly fo ; but we find a great deal of Milton's manner in the progrefs of the tale, written in view of the rocks on which the Halfewell fruck.

\section{LEWESDON HILL.}

See bow the fun, here clouded, afar off

Pours down the golden radiance of his light

Upon th' enridged fea, where the black thip

Sails on the phofpher-feaming waves.-So fair,

But falfely flattering, was yon furface calm,

When forth for India fail'd, in evil hour,

That veffel, whofe difaftrous fate, when told,

Fill'd every breaft with horror, and each eye

With piteous tears, fo cruel was the lofs!

Methinks I fee her, by the wintry. ftorm

Shatter'd and driven along paft yonder ifle!

She ftrove, her lateft hope by ftrength or art,

To gain the port within it; or at worft,

To thun that harbourlefs and hollow coaft,

From Portland eaftward to the Promontory,

Where ftill St. Albans high-built chapel ftands.

But art nor ftrength avail her, on the drives,

In ftorm and darknefs, to that fatal coaft!

And there, mid rocks and high o'erhanging cliff,

Dafh'd piteoufly, with all her precious freight 
Was loft, by Neptune's wild and foamy jaws

Swallow'd up quick! The richlieft laden thip

Of fpicy Ternate, or that, annual fent

To the Philippines o'er the fouthern main

From Acapulco, carrying maffy gold,

-Were poor to this; freighted with hopeful youth

And beanty, and high courage undifmay'd

By mortal terrors; and paternal love,

Strong and unconquerable, even in death.

Alas! they perin'd all,-all in ONE HOUR !

Refuming the principal fubject of thefe ftrictures, we find the harmonic difcoveries attributed to the acrial hand-maids. Their miftrefs fuppofes them to have breathed their grand and exquifite infpirations into the ear of Handel; to wake the tones on the fhell of Echo; to melt in fweet chords upon the Eolian harp; and on the lips of Cecilia to breathe the fong. Another lovely picture arifes here, from an ancient gem, Cupid on a Lion's back, playing on a lute.

The Goddefs proceeds to confider her Nymphs 
Nymphs of Air as Minifters of Divine Vengeance on the Guilty, through the medium of temperts, and the peftilential winds of the Eart, as Samiel, Harmattan, \&c. and the fcripture ftory of the fate of Senacherib is told. The ravage of death, produced by thofe peftilential gales, forms a fublime perfonification ; thus,

Hark ! or the camp the venom'd ternperf fings! Man falls on man; on buckler buckler rings;

Groan anfwers groan; to anguifh anguifh yields, And death's dread accents frake the tented fields. High rears the Fiend his grinning jaws, and wide Spans the pale nations with coloffal fride:

Waves his broad falchion with uplifted hand, And his vaft thadow darkens all the land I

Whether by coincidence or plagiarifm on the part of Dr. Darwin, is uncertain, but in Mr. Sergeant's noble prophetic Ode on the Woes of the Houfe of Stuart, commencing with fair unfortunate Mary's calamities, we find the laft fublime image, thus, 
From Orkney's formy fteep

The fpirit of the inles infuriate came;

Round him flafh'd the aretic flame, His dark cloud hadow'd the contentious deep !

This Ode was publined in 1788 . The Economy of Vegetation in 1791 .

That poem proceeds with another exhortation to the etherial Cohorts to protec the vernal children; impart the talifman which guides the veering winds, and, by it's influence, enchain Borcas and Eurus, fo often fatal to early luxuriance, vegetable and animal. Thus fhall they, the beautifully fays,

Rock th' uncurtain'd cradle of the year.

The deftruction and reproduction of the atnofphere, is allegorifed by a monfter of magnitude more immenfe than that of Satan, when, on the page of Milton, he ftrides from hill to hill. This is a Camelion beneath the northern confellation. 
We find much grandeur of fancy in this aerial giant. His groan is the thunder, his figh the tempert, as he fteers his courfe to the fouth, and fpreads his thadowy limbs over the line, with froft and famine in his track. The Sylphs are adjured to direct his courfe to benevolent purpofes; to cool Arabian vales with his antarctic breathing; and, in the following harmonious line,

To fcatter rofes o'er Zelandic fnows.

This allegory concludes unhappily, with a perfonal compliment to Mr. Kirwan, "who has publifhed a valuable Treatife " on the temperature of Climates." Thofe compliments to ingenious profeffors would often find their more proper place in the notes, except where they form a fimile; but, as in this inftance, a living man placed between the dragon wings of an imaginary and immeafurable monfter, is a ridiculous idea. 
idea. Often, through the courfe of this work, does fuch intermixture of actual and ideal beings difturb and interrupt, rather than agreeably diveriffy, the courfe of the allegory. The foon-enfuing mention of the celebrated Herfchel, and his ftellar difcoveries, is made in the form of a fimile, and is therefore unexceptionable; and it paffes on to the following charming aportrophe to the Stars.

Roll on, ye Stars! exult in youthful prime, Mark, with bright curves, the printlefs fteps of Time!

Near, and more near, your beamy cars approach, And leffening orbs on leffening orbs incroach. Flowers of the $\mathrm{ky} /$ ye too to age muft yield, Frail as your filken finters of the field;

Star after ftar from heavn's high arch fhall rufh, Suns fink on funs, on fyftems fyftems rufh; Headlong, extinct, to one dark centre fall, And Death, and Night, and Chaos cover all; Till o'er the wreck, emerging from the ftorm, Immortal nature lifts her changeful form;

Mounts from the funeral pyre on wings of flame, And foars, and fhines, another and the fame. 
Returning to the vegetable cmbryons, of which the Goddefs, between her mention of Kirwan and Herfchel had fpoken, the thus beautifully fays:

Lo! on each feed, within it's tender rind, Life's golden threads, in endlefs circles wind;

Maze within maze the lucid webs are roll'd, And, as they burft, the living flames unfold.

The whole paffage is equally fine, and clores thus:

Life buds, or breathes, from Indus to the Poles, - And the vaft furface kindles as it rolls.

We find the fame image applied to Light in the firft Canto, as it is here to Vitality. Spcaking of Chaos the Poet fays:

Through all his realms the kindling Ether runs:

Yet, far from cenfuring the very infrequent repetitions, which we may find through this great work, wonder and praife 
will rife in the mind of every true lover of the poetic art, contemplating that exhauftlefs variety of ideas, imagery and expreffion, which light up the fubject with a thoufand torches, kindled at the orb of Genius.

Skilful blendings of philofophic knowledge with poetic fancy, now occur in the birth and growth of plants and flowers. They are compared to the kindling and expanfion of animal life in the Crocodile, burfting from it's egg on the Thores, of the Nile. It is a grand picture, though of fomewhat forced introduction. The charge on it's progrefs contains inftruction to gardeners, though it is addreffed to the Sylphs, and adorned by the parable of Aaron's rod. The banimment of noxious infects by their cares, is enforced by the example of the Cyprepedia, a flower curioufly refembling the large American Spider. Linneus afferts, that it catches fmall birds 
as well as infects, and has the venomous bite of a ferpent; and a French naturalift narrates, that it catches the humming bird in it's frong nets. The circumftance is thus elegantly piatured in the Botanic Queen's horticultural adjurátions,

So where the humming-bird, in Chili's bowers, On r rmuring pinions robs the pendent flowers; Seeks where fine pores their dulcet balms difill, And fucks the treafure with probofcis bill, Fell Cyprepedia, \&c.

The difeafes of plants are next pointed out, and they are illuftrated by a curious fact in glafs-making. The pictures of various flowers next rife on the page, in botanic difcrimination, and in all the hues of poetry. The exotic wealth of the Royal Garden at Kew is celebrated; and the confcious pride of it's river, on the occafion, is thus fweetly fancied:

Delighted Thames through tropic umbrage glides, The flowers antarctic bending o'er his fides;

Drinks the new tints, the fcents unknown inhales, And calls the Sons of Science to the vales. 
Poetic homage is then paid to our King and Queen, to their virtues, their tafte for Botanic Science, and to the fair human Scions which themfelves have raifed.

The Godders compliments her aerial Legions on attending the chariot of the Morning round the earth, on leading the gay Hours along the horizon; on fhowering the light an every dun meridian, and on purfuing, from zone to zone, the perennial journey of the Spring. She commiffions them, on this their radiant tour, to bring her rich balms from the hallowed glades of Mecca, Arabian flowers, Italian fruits, and the tea-plants of China; alfo

Each fpicy rind which fultry India boafts,

Scenting the night-air round ber breezy coafts;

Roots, whofe bold ftems in bleak Siberia blow, And gem with many a tint th' eternal fnow;

Barks, whofe broad umbrage high in ether waves

O'er Ande's fteeps, and hides his golden caves.

Thus, with happy art, the Poet diverfifies

$$
\text { T } 4
$$
and 
and animates floral enumeration with gleams of every-regioned landfcape.

The Sylphs are then commanded to raife an altar to Hygeia ; to call to it's rites the difperfed Sifterhood, the Water Nymphs, from their floating clouds, their waves and fountains; to ftamp with charmed foot, and convoke the Gnomes from their fubterranean palaces; and to beckon from their fpheres the veftal forms of fire; that thus, in full congregation, they may win the Goddefs of Health with unwearied vows. The picturefque attitudes of fupplication, which the dictates, are eminently beautiful; and, with a patriotic apoftrophe to Hygeia, the Britim Queen of Botany concludes her embaffy.

O wave, Hygeia, o'er Britannia's throne Thy ferpent-wand, and mark it for thy own! Lead round her breezy coafts thy guardian trains, Her nodding forefts, and her waving plains! Shed o'er her peopled realms thy beamy fmile, And with thy airy temple crown her ifle! 
The Goddefs of Botany now afcends with as much elegance as the had defcended, and with more magnificence. If the reader is fufceptible of poetic beauty; if he can feel that what never can be feen in reality, may yet be painted naturally; a ftrict furvey of this poetical afcenfion will enable him to perceive, what indeed countlefs other inftances in this Poem evince, that it's Author moft eminently poffeffed that rare talent.

The Goddefs ceas'd, and calling from afar The wandering Zephyrs, joins them to her car; Mounts with light bound, and graceful as the bends, Whirls the long lan, the flexile rein extends; On whifpering wheels the filver axle nides, Climbs into air, and cleaves the cryftal tides; Burft from it's pearly chains, her amber hair Streams o'er her ivory thoulders, buoy'd in air; Swells her white veil, with ruby clafp confin'd Round her fair brow, and undulates behind; The leffening courfers rife in fpiral rings, Pierce the flow-failing clouds, and ftretch their thadowy wings. 
If we could fee a light vehicle mount the horizon, it's wheels would whifper, it's axle flide; fo would it climb into air, fo divide the etherial currents, as a boat divides the waves of the river or the fea ; the courfers would rife in fpiral rings and pervade the clouds; their wings would appear hadowy till they melted into air. Thus concludes the Economy of Vegetation. 


\section{CHAPTER YI.}

WE now come to yet more playful compofition in the fecond part of this Poem, as the floral fyftem is a lighter and lefs important theme than the elementary properties, however generally gay the robes in which poetic imagination has dreffed them both; but let it never be forgotten that the fexual nature of plants has a demonftrated exiftence.

The Preface to this fecond part is a compendium of the Linnean fyftem. The Poem makes lively, yet very modert claims for the fucceeding metamorphofes, amid whofe lighter graces we meet with paffages of intrinfic grandeur and fublimity. 
LOVES OF THE PLANTS.

In which the Poet ordains that the Mufe of Botany Rall fucceed to it's afcended Emprefs, as hiftorian of the fcene, and dictatrefs to it's dramatis perfonæ. He introduces her by invoking, in his own perfon, the attentive filence of the winds, the waters, and the trees, and by requefting the infects to paufe upon their wings. Eight different infects are mentioned, and each forms a friking picture of it's whole fpecies, by the Poet having feized and exhibited it's mort characteriftic feature. He next apoftrophifes the Mufe who "led the "Swedim Sage by her airy hand," intreating her to fay how tiny Graces dwell on every leaf, and how the Pleafures laugh in the bell of a bloffom.

The Ovidian metamorphofis of the flowers then commences. The floral ladies, and their harems, rife to the amufed eye 
in all the glow of poetic colouring. Attentive to diverfify them by the varieties of landfape, we generally find this Poet producing contrafted fenery by the introduction of flowers or plants which are indigenous to climates ftrikingly the reverfe of each other. Much of that happy fkill has been difplayed in the Economy of Vegetation, and inftances may be felected from this it's brilliant precurfor. After feveral plants and flowers have paffed before us in the femblance of beautiful wo. men, with their trains of adoring lovers, we find the following fketches of contrafted landfcape attached to the biftory of the focial heath-plant, Anthoxa, or vernal grafs, and the lonely Ofmunda, which grows on moift rocks and in their caverns.

Two gentle Thepherds, and their fifter wives,

With thee, Anthoxa, lead ambrofial lives;

Where the wide heath it's purple bed extends,

And fiatter'd furze it's golden luftre blends, 
Clos d in a green recefs, unenvied lot!

The blue fmoke rifes from their tarf-built cot;

Bofom'd in fragrance bluth their infant train, Eye the warm fun, and drink the filver rain.

Befuteous Ormunda feeks the filent delf, The ivy canopy, the dripping cell.

In the defcription of the Chondrilla and her five amicable lovers, we find, in their accordant fympathy with each other, a fuppofed refemblance to the unifon-ftrings of the Eolian harp; and there is a fweet enumeration of the excellences of it's varied ftyle of tones and expreffion.

To the picture of the Lychnis fucceeds that of Gloriofa Superba, with her fucceffive train of loyers, the fecond number rifing to maturity when the firft periih. This libertine lady of the groves introduces the. Ptory of the celebrated female Voluptuary, in the reign of Louis the Fourteenth, Ninon de L'Enclos, whofe beauty and graces are recorded to have been triumphant 
phant over the power of Time. The ftory of that paffion, fo terrible in it's confequences; with which fhe unintentionally infpired her natural fon by Lord Jerfey of England, is finely told in this part; that fon, totally unconfcious of his birth and fatal nearnefs of blood to the charming. Madam de L'Enclos! In the firft edition of the Loves of the Plants this extraordinary woman received both perfonal and mental injuftice from the prelude to that ftory. She is there reprefented by the Poet, as wrinkled, grey, and paralytic; circumftances incompatible with the poffibility of the attachment, and contrary to the reprefentation of her biographers. Upon their teftimony we learn that Ninon retained a large portion of her perfonal beauty and graces to an almoft incredible period; that it was confiderable enough to procure her young lovers at the age of eighty, 
eighty, whofe paffion for her, however inconceivable, could not be interefted, as The was not rich, and much too delicate in her fentiments to purchafe the attention of the other fex.

When her fon, by Lord Jerfey, was a young officer about Court, known to her but unknown to himfelf, Madame de L'Enclos was farcely forty years old, a period at which a very captivating degree of beauty and grace is fometimes found in the female fex. Of their exiftence at a confiderably later petiod, the Englifh farhionable circles, at this hour, exhibit forne remarkable inftances.

In the firft edition of this Poem what is here fatal fmiles was harlot fmiles, an epithet moft injurious to Madame de L'Enclos. Her attentions to her fon, however affectionate, muft have been purely maternal, though fo deplorable in their 
their confequences. The declaration by which the repulfes his impious fuit, entirely acquits her of the leaft defign to infpire him with paffion. Dr. Darwin was influenced by the author of this Memoir to refcue the form of Ninon from the unreal decrepitude he had imputed to it, and her principles from fuch unnatural excefs of depravity.

If we may credit her hiftorians, Ninon was an exception to a maxim of the Duke de Rochefaucault, which has perhaps very few exceptions, viz. "Generally fpeaking, " the leaft fault of an unchafte, woman is " her unchaftity." Confidering this remark as an axiom, the reafon probably is, that chaftity being the point of honor, as well as of virtue in women, it's violation has a ftrong tendency to engraft deceit and malignity upon the fecret confcioufnefs of felf-abafement; a confcioufnefs more fatal to the exiftence of other good qualities 
than voluptuoufnefs itfelf; a confcioufnefs too likely to produce hatred and envy towards people of fpotlefs reputation, together with a defire to reduce others to their own unfortunate level. The great Moralift of the Old Teftament, fays," There is " no wickednefs like the wickednefs of a "woman;" not becaufe the weaker fex are naturally more depraved, but from the improbability that a fallen female hould ever, even upon the fincereft repentance, regain the efteem and confidence of fociety, while it pardons a male libertine the inftant he feems difpofed to forfake his vice, and too often during it's full carcer.

But the fault of Madam de L'Enclos was fingle, and furrounded by folid virtues. Truth, fincerity, difinterefted friendihip, economy, generofity, and ftrict pecuniary juftice, marked her commerce with the world, and fecured to her the friendfhip and countenance of the moft eminent 
people of that epoch, both as to talents and character.

The rigid and pious Madame de Maintenon never ceafed to be her avowed and intimate friend, as appears from a moft interefting dialogue which paffed between them after Maintenon became the wife of Louis the Fourteenth. It will be found in the Memoirs of Madame de L'Enclos, which are elegantly tranflated from the French into our language, and were publifhed by Dodfley in 1761 . It is a very brilliant and entertaining work.

After the animation of the Silene, or Catch Fly, as an enchantrefs; after that of the Amarylis, illuftrated by a beautiful picture of a church vane in the fetting fun, the Ilex, or Holly, comes forward with her giant lovers, grafping their thoufand arrows. With this metamorphofis we find involved a lovely allufion to Needwood Foreft, the late pride and glory of Staffordhire, now 
facrificing, with all it's proftrate honors, to a popular fcheme of apprehended utility.

- Mr. Wright's pictures are here introduced as a fimile; but it muft be confeffed that not the moft diftant fimilitude can be traced between them and the Ilex, or Holly, which, as enchanters and giants, guard the Foreft; but the poetic copy of thefe unallufive landfcapes is tranfcendent.

The immenfe Kleinhovia, indigenous to the plains of Orixa, is prefented as an amazonian nymph; and as the male parts or the tree are, in nature, fupported by the female, the is pourtrayed in Herculean beauty, bearing in her arms her puny lovers, trembling beneath the confcioufnefs of her fuperior ftrength. A grand picture of the Grecian Thaleftris, appropriate to the fubject, thus illuftrates the transformation:

So bright Thaleftris thook her plamy creft, v. And bound in rigid mail her fwelling breaft, 
Pois'd her long lance amid the walks of war, And Beauty thunder'd from Bellona's car;

Greece, arm'd in vain; her captive heroes wove The chains of conqueft with the wreaths of love.

The noble landfcape of the late and wintered period of Autumn, quoted in an early part of thefe Memoirs, introduces the perfonification of the Tulip. The bulbous root of flowers is termed by Linneus the hybernacle, or winter-lodge of the young plant. He fays, " Each bulb contains the "leaves and flowers in miniature, which " are to be expanded in the enfuing fpring." The fame embryon miniatures are found in the buds of the Hepatica, the DaphneMezereon, and at the bafe of OfmundaLunaria. The Tulip, in poetic animation, is a beautiful Matron, flying from the chill and ftormy feafon to a lone cavern. She is then prefented as fitting in that retreat, and nurfing her infant on her bofom till warmer days thall come. A pretty allufive

$$
\text { U } 3 \text { defcription }
$$


defcription of the Dor-moufe, and it's half-year's number, adorns that paffage.

Colchicum Autumnale, or Autumnalmeadow-fweet, afcends amid the troubled air, with her attendant lovers. Thus eminent in beauty is the ftellar fimile for that flower:

So Thines, with filver guards, the Georgian ftar, And drives, on Night's blue arch, bis glittering car; Hangs o'er the billowy clouds his lucid form, Wades through the mift, and dances in the ftorm.

The Helianthus, or Sun-flower, becomes a Dervife, and leads his devout trains to wornip the rifing orb of day. Since the head of that majeftic plant always, and by nutation, follows the courfe of the fun, it properly affumes the name and habits of a Dervife or Bramin. With this and the three fucceeding metamorphofes, in themfelves full of beauty and grace, the Drofera, or Sun-dew, the Lonicera, or Honey-fuckle, and the Alpine Draba, fweet traits of con- 
trafted landfcape are blended; with Helianthus, the warm unhadowed lawns of morning; with Drofera the moift, the rufh-enwoven and moffy fcenes in which the wantons; with Draba, the icy caves and volcanos of Tenerif, amid which the builds her eyry,

Afpiring Draba builds her eagle neft;

and we are told that,

Her tall hadow waves o'er the diffant land.

When we learn, from the note on this paffage, that Draba is one of the Alpine graffes, we wonder that fo minute and dwarfin a plant hould become fo vaft commanding, and imperial in her tranfformation. The Poet next exercifes his Proteus art upon Vifcum, Mifletoe, which never grows upon the ground, but grafts itfelf upon the branches of trees. This aerial nymph is thown as an angel of air, feeking amongft it's clouds her foaring lovers. 
When Zoftera, Grafiwrack, (which grows at the bottom of the ocean, and, rifing to it's top, covers many leagues with it's leaves, ) comes forth from beneath the wand of this potent magician, we meet one of the happieft fallies of his fportive pen. She is thown as Queen of the coral groves; her palace in the fea, fupported on cryftal columns; it's turrets roofed with lucid Thells, which dart their every-coloured rays afar into the deep; the fhadows on it's floor, philofophically defcribed from the rifing and breaking of the exterior billows; the mermaid-train enweaving orient pearls in her hair; her fhooting up to the furface like a meteor; afcending the ftrand, and fummoning, by a loud-ftruck fhell, her fea-born lovers to attend her progrefs; creative imagination, the high and peculiar province of the genuine Poet, has few more beautiful creations than this marine picture and fcene. 
That curious plant of the polar regions, the Barometz, from it's exterior refemblance to a neep or lamb, is, by poetic magic, transformed into that animal, and to it the Whale is compared; furely on no other poffible relation, than as both the odd plant and the fea-monfter, are natives of the arctic regions. The Whale, however, makes a grand poetic picture:

Since then, the thing itfelf is rich and rare, Exclaim not, "How the d-1 came it there*!"

Mimofa, Senfitive-plant, becomes a nymph of infinite delicacy. The objects aptly chofen to illuftrate the nervous fenfibility with which that plant recedes from the approaching hand, are thus defcribed, and furely with no common happinefs:

So finks, or rifes, with the changeful hour,

The liquid filver in it's glaffy tower;

So turns the needle to the pole it loves,

With fine vibrations quivering as it moves.

- Parody of Pope's lines on the Amber. 
The Anemone and her modern-life objects of comparifon, by no means form one of the gems of this poem, however harmonious the lines. A lady's calarh and a landau are out of their place in high heroic numbers. The Anemone and her trivialities, are fublimely contrafted by the rockborn Lichen, both in feenery and accomplifhment. She has too much dignity from her furrounding landfcape to have, or to want an illuftrative fimile. Her habitation is on the top of Snowdon, nodding over the tumultuous river Conway; the hour midnight; the ftars and cold moon gilding the rifted rocks; the whirlwind and dark thunder-ftorm rolling and burfting below the fummit of the mountain. From it's topmoft ftone the transformation of the Dipfaca conveys us to a valley glowing beneath the long prevalence of the dog-ftar, when the channel of every rill is dry, and the parched earth gapes. The perfoni- 
perfonification of the plant has every graceful charm of a languid beauty.

The Rubia, Madder, a plant ufed for the purpofe of making a crimfon dye, is compared to Medea bending over her caldron, in which youth was reftored by immerfion. It is an apt allufion to the faded beauty, who reftores her loft bloom by rouge.

-Vallifner, a curious aquatic plant of the Rhone, apoftrophifes, when, in her human form, the ftars and moon, fhining at midnight on the fhores of her watery home; and the fea-weed, Ulva, with her young family, guarded on the deep by Halcyons, ferves to introduce the famous Galatea in her fhelly chariot, drawn by Dolphins over the Ocean. She has more ftate and more fuperb attendants on her maritime progrefs, than Europa, in the fecond Canto of the Economy of Vegetation, or than the Nereid, in the third; though in the picture of

Galatea 
Galatea there is perhaps a lefs degree of originality.

But, upon the transformation of the Tremella, Star-jelly, (a fungus often found in the ftate of tranfparent jelly, after it has been frozen in autumnal mornings, ) the Poet has lavifhed fome of the finert effufions of his fancy. It is furely the tranfcendent paffage of this fecond part of Dr. Darwin's Poem. No eye has feen, or ever can fee a beautiful Nymph frozen into an ice-ftatue; but admit the poffibility, and every circumftance of the gradual petrification is no lefs natural than it is lovely; nor can any degree of admiration be too high for the beauty and grace of the defcription. It is fuperior to the Ovidian Daphne.

This Canto now prepares to clofe; the Mufe of Botany perceives a tempeft approaching, and the is led by Wood-Nymphs into their moft fequeftered bowers. They fufpend her lyre upon their laurel trees, and 
bind her brow with myrtles. If the had no other claim, the Tremella alone ought to give her wreath unperifhable bloom. Symptoms of the impending fhower are given with that accuracy, with which, on every occafion, this genuine Poet obferved the objects of nature, thus:

Now the light fwallow, with her airy brood, Skims the green meadow and the dimpled flood.

5 Loud Arrieks the lone thrufh oin her leaflefs thorn; Th' alarmed beetle blows his bugle horn;

Each pendant fpider weaves, with fingers fine, - Her ravell'd clue, and climbs along the line; Gay Gnomes, in glittering circles, ftand aloof Beneath a fpreading muthroom's ample roof; Swift bees, returning, feek their waxen cells, And Sylphs hang quivering in the lily's bells

Through the fill air defcend the genial fhowers, And pearly rain-drops deck the laughing flowers.

An Interlude in profe fucceeds to this Canto. It is a fuppofed dialogue between the Poet and his Bookfeller, in which the former gives us his ideas of the conftitution 
of true Poetry. His firft fpeech," I am " only a flower-painter, or occafionally " attempt a landfcape," is neither true, nor did Dr. Darwin defire that it thould be confidered as veritable.

In the courfe of this Interlude he will be found making much higher claims for himfelf, and too exclufively limiting poetry to the fphere of picturefque expreffion; yet his criticifm on this line in Pope's Windfor Foreft is perfectly juft,

And Kennet fwift, for filver Eels renown'd.

Since, whenever objects are introduced in verfe, which, plainly mentioned, can excite no intereft, it is queftionlers the Poet's duty to awaken interefting remembrance of them by little picturefque touches, fuch as we find in the Doctor's fuggefted change of that line, to

And Kennet fwift, where filver graylings play.

His ftricture upon Burke's ftyle in profe; 
as much too ornamented, has furely little juftice. Eloquence can only be produced by a frict union of ftrength and ornament. The Corinthian pillar is not lefs ftable than the Doric; not lefs firm on account of it's flowers. Dr. Darwin here feems to wifh that profe thould be precluded by it's plainnefs from rifing into eloquence. $\mathrm{He}$ wifhed to keep profe too plain, and his warmeft admirers will furely acknowledge that he infifts upon poetry being dreffed with too elaborate magnificence. We find him in this Interlude, very ingenious on the fubject of allegoric figures, alfo on that of dreams, and in his comparifon of them to the reveries which the true Poet excites in his intelligent readers; but he is greatly indeed miftaken when he reprefents the art of exciting fuch rapt and abftracted fenfations as folely confifting in picturefque writing. Inftruction, pathos, all the grandeur and beauty of moral and religious

fentiment, 
fentiment, are here turned over to the profe writer, as if they were not equally capable of giving fafcinating power to verfe, as well as to oratory. The following paflages are not picturefque; but no pictures ever prefented by the mufes, are more potent to imprefs, thrill, and captivate that mind which is alive to the magic influence of their art:

Some fay, that, ever 'gainft the feafon comes At which our Savior's birth is celebrated, The bird of dawning fingeth all night long; Aud then, they fay, no fpirit walks abroad; The nights are wholefome; then no planets ftrike, No fairy takes, no witch hath power to charm, So hallow'd and fo gracious is the time!

HAMLET.

- I fled, and cried out-Death $i$

Hell trembled at the hideous name, and figh'd Through all her caves, and back refounded-Death !

\section{Milton.}

\section{- nhaig sily $\rightarrow$ if prayers \\ Could alter high decrees, I to heaven's throne Would fpeed before thee, and be louder heard}


That on my head all might be vifited, Thy frailty and infirmer fex forgiven, By me committed, and by me expos'd.

MiLTON.

Remember March! the ides of March remember ! Did not great Julius bleed for juftice' fake? What villain touch d his body, that did ftab, And not for juftice? What I thall one of us, That ftruck the foremoft man in all the world But for fupporting robbers, fhall we now Contaminate our fingers with bafe bribes, And fell the mighty fpace of our large honors For as much trafh as may be grafped thus ?.

1 had rather be a dog, and bay the moon,

Than fuch a Roman.

$$
\text { JuLIUS CESAR, }
$$

Plac'd on this ifthmus of a middle ftate,

A Being datkly wife and rudely great;

With too much knowledge for the Sceptic fide,

With too much weaknefs for the Stoic's pride,

He hangs between, in doubt to act or reft,

In doubt to deem himfelf a god or beaft;

In doubt his mind or body to prefer,

Born but to die, and reafoning bat to err;

Sole judge of truth, in endlefs error hurl'd,

The glory, jeft, and ridale of the world.

Popx, on the Conftruetion of Man. 
Not e'en a fpot unfought the hero gave,

No! till his foes had earn'd it, not a grave!

Wescex, of King William the Third.

Reflect, that leffen'd fame is ne'er regain'd,

That virgin honor once is always ftain'd!

Timely advis'd the growing danger fhun,

Eetter not do the deed than weep it done!

No penance can abfolve a guilty flame,

Nor tears, that wafh out fin, can wafh out thame.

Henry and Emma.

Methought I heard a voice cry, Sleep no more!

Macbeth doth murder neep! the innocent fleep !

Sleep, that knits up the ravell'd neeve of care,

The death of each day's grief, fore labour's bath,

Balm of hurt minds, chief nourither in life's feaft ?

Still it cried, Sleep no more, to all the houfe,

Glamis hath murder'd fleep, and therefore Cawdor

Shall neep no more, Macbeth fiall neep no more!

Who will call thefe paffages profaic? Who are they that will not confefs them to be poetry, and fuch poetry as requires no aid from picture to eftablifh it's claims?

Perhaps 
Perhaps Dr. Darwin would not have deemed them fufficiently adorned, fince all there is to the heart and nothing to the eye. To be confiftent with the criticifm of this his Interlude, he muft have afferted their deficiency, and thus have proved that, while his imagination was fo richly exuberant; while fublimity, as well as beauty, attended the commanding march of his Mufe, there was a radical defect in his poetic fyftem, which would for ever have incapacitated him from being a firft-rate Epic or Dramatic writer; but as nature hovered over the cradle of Shakefpear, and gave him her golden keys, to unlock the gates of the Paffions, fo did Imagination over that of Dr. Darwin, and put into his grafp her magic wand, and fpread over his form her every-coloured robe.

\section{SECOND CANTO.}

Again the Goddefs trikes the golden lyre, And tunes to wilder notes the warbling wire, 
With foft, furpended ftep Attention moves, And Silence hovers o'er the liftening groves.

The fecond line of the paffage is too alliterative, and therefore palls upon the ear. Alliteration is an edge tool in the Poet's hand, improving or injuring his verfe, as it is judicioufly or injudiciounly ufed. Homer, Virgil, Ovid, Spenfer, Milton, and all the beft poets, have employed it to admirable effect; and to admirable effect has Dr. Darwin frequently employed it, though not in this inftance. It often increafes, and fometimes entirely conftitutes, that power which, by a metaphoric expreffion that literal terms would neither fo concifely nor fo well explain, is called picturefque found. To increafe the harmony of verfe, alliteration muft be with the vowels, the liquid letter $l$, or by the fonorous letters $m$ and $n$, and even with them it's too frequent ufe in a poem, or too lavifh repetition in a fingle line or couplet, will injure what it is defigned 
to improve, as in the above fecond line of this fecond Canto. Dryden, in his noble Ode on St. Cecilia's Day, has alliterated with the hiffing $f$, in two lines, which he meant fhould be peculiarly mufical ; thus,

Softly fweet in Lydian meafures

Soon he footh'd the foul to pleafures.

A foreign ear would not endure the lines, which, however lively, are certainly not tender, not harmonious; yet the $\int$, and all the harfher confonants, are capable of producing, by fkilful application, that " echo of found to fenfe," which is fo cminently defirable in poetry. When Milton obferves in the Paradife Lort,

So talk'd the fpirited ny fnake,

the line attains, folely by alliteration, the perfect hifs of the ferpent; and Pope, in his Homer, by a mafterly intermixture of the vowels and the fonorous confonants 
with his alliteration of the letter $f$, has nobly conveyed to our ear the peculiar noife of the ocean-waves when they are loud on the beach; thus,

Silent he wander'd by the founding main.

The murmur of a calm fea has been well expreffed by the alliteration of the following line:

Slow on the damp and thelly thore fhe ftray'd.

There is fomewhere a line, in which a poetafter, mentioning the violet, fays,

Where blue it blooms with balmy breath.

He thought he had hammered out an immenfely fine verfe, though in fact it is to the ear no whit more agreeable than,

Three blue beans in one blue bladder.

The letters $b$ and $p$ make miferable alliteration. Milton has ufed the harfh letter $r$, to very fine effect in the following lines: 
Vex'd Scylla, bathing in the fea that parts

Calabria from the hoarfe Trinacrian thore.

Dr. Beattie, in his charming Minftrel, has fo ufed alliteration as to produce two of the mort harmonious verfes in our language.

Young Edwin, lighted by the evening ftar,

Lingering and liftening, wander'd down the vale.

This digreffion into general criticifm will not be thought irrelevant to the peculiar theme of thefe pages, when it is confidered that, for the prefumption of cenfuring, even in one inftance, the eminently harmonious numbers of the Botanic Garden, it was requifite to juftify fuch cenfure by examining the ufe or abufe of that habit of ftyle, which ftrengthens or enfeebles, adorns or minbecomes the verfe, as the good or bad tafte of the writer fhall direct it's application. Churchill has ridiculed alliteration in a line of fingular felicity, for an unworthy

$$
\text { x } 4 \text { purpore, }
$$


purpofe, a fatirical paffage on the beautiful poetry of Mafon; thus,

\section{I, who never pray'd}

For apt alliteration's artful aid.

But the ridicule intended for the fweet Swan of the Humber, falls equally on the elder claffics of Greece, Rome, and England.

The firft transformation of this fecond Canto is the Carline Thiftle. We learn, from a note on the paffage, that it's feeds are furnifhed with a plume, by which they are borne through the air. Carlina, in human thape, is reprefented as fabricating Dxdalion wings for herfelf and offspring, with moft ingeniounly defcribed mechanifm, and with happier fuccefs than thofe of the renowned mechanic in ancient fable.

And now fucceeds, in happy fimilitude, a balloon-voyage, exact and accurate to the circumftances of acrial journeying in the firf inftance, and fublime in the imaginative 
native part, the aftronomic allufions: they are thus given:

Rife, great Mongolfier! urge thy venturous flight

High o'er the moon's pale, ice-reflected light;

High o'er the pearly ftar, whofe beamy horn

Hangs in the eaft, gay harbinger of morn;

Leave the red eye of Mars on rapid wing, Jove's filver guards, and Saturn's dufky ring;

Leave the fair beams, that, iffuing from afar, Play, with new luftre, round the Georgian ftar; Shun, with ftrong oars, the fun's attractive throne, The fparkling zodiac, and the milky zone, Where headlong comets, with increafing force, Through other fyftems bend their blazing courfet For thee Caffiope her chair withdraws, For thee the Bear retracts his Mhaggy paws. High o'er the north thy golden orb thall roll, And blaze eternal round the wondering pole. So Argo, rifing from the fouthern main, Lights with new ftars the Blue, etherial plain; With favoring beams the mariner protects, And the bold courfe, which firft it fteerd, direets.

So beautifully does this high prieft of Fancy choofe to conftellate the firft adventurous Aeronaut. 
In the animation of Linum Flax we are prefented with the exacteft-poffible defcription of the machinery, and the art of weaving; and in that of Gofflipiam, Cotton Plant, the late Sir Richard Arkwright's apparatus at Matlock, with the whole progrefs of it's operations, is brought diftinctly before the eye, recalling them to thofe by whom they have been examined, and inftructing in their progrefs thofe who never beheld them.

So, in the perfonification of Cyperus Papyrus, under the name of Papyra, another art, that of printing, paffes before us with equal precifion. The leaves of this plant werc firft ufed in Egypt for paper, and gave the name, which it retains to this day; fo, leaf, or folium, for the fold of a book. We have here, in fweet verfification, the whole procefs of that ineftimable invention, which paints thoughts, founds, and numbers, in myftic and imperifhable characters ; 
characters; imperifhable, at leaft, during the reign of Time. Yes, it was the encouragement given by that art to the fciences, which enabled this Bard to throw over them all his fplendid robe of defcriptive poefy. The venerable and celebrated Mrs. Delany, fometime deceafed, and her miraculous Hortus Siccus, are here introduced as a fimile to Papyra; but defcribing a totally different art from hers, even that of a mere artificial flower-maker, this fimile, which bears fo little refemblance to writing and printing, forms one of the moft cenfurable paffages in the whole poem. Mrs. Delany, in her reprefentation of plants and flowers, native and exotic, and which fill ten immenfe folio volumes, ufed neither the wax, mofs, or wire, attributed to her in this entirely falfe defcription of her art. She employed no material but paper, which the herfelf, from her knowledge of chemiftry, was enabled to dye of all hues, 
and in every thade of each; no implement but her feiffors, not once her pencil; yet never did painting prefent a more exact reprefentation of flowers of every colour, fize, and cultivation, from the fimple hedge and field-flower, to the moft complicated foliage that Horticulture has multiplied. This lady, once Mrs. Pendarvis, the friend and correfpondent of Swift, and in her later years honored by the friendihip and frequent vifits at Windfor, of the King, Queen, and Princeffes, began this her aftonishing felf-invented work at the age of feventy-four. The Poet here mifreprefents her as being affifted by her virgin train. She had no affiftant; no hands, but her own, formed one leaf or flower of the ten volumes. Her family were mortified by a defcription which they juftly thought degraded her peculiar art; and remonftrated with Dr. Darwin on the occafion, expreffing a wifh that future editions might contain 
tain it's more juft pidure on his poetic page. He faid, the defcription in the note was accurate; but that truth in this, as in many other inftances, being lefs favourable to poctry than fiction, he did not chore to alter the text.

The Leprana, the Nymphea alba, and the Calendula, whofe flowers, as do many other flowers, open and fhut at certain hours of the rifing and declining day, are transformed into elegant female watchmakers. Linneus calls the forty-fix flowers of this order, the Horologe, orWatch of Flora. This transformation involves an highly poetic defcription of the art that traces the march of Time. The progreffive mechanifm which completes a watch, is traced with accuracy, and, in the mention of it's ornamental trophies, we meet fublime imagery; fuch as Time dafhing Superftition from it's bafe, and the Hours leading their trains around the wreck; but 
the Moments are imperfonized with too much quaint prettinefs. The whole of this imagery is an imitation, as indeed the Author afterwards acknowledges, of the following paffage in Young's Night Thoughts,

Each Moment has it's fickle, emulous

Of Time's enormous fcythe, whofe ample fweep

Strikes empires from the root; each Moment plies

His little weapon in the narrower fphere

Of fweet domeftic comfort, and cuts down

Our faireft blooms of fublunary blifs.

The Hours leading their trains around the wrecks their parent had made, and planting amidft them the growth of fcience and tafte, is an original and beautiful addition in Dr. Darwin's imitative paffage. The Moments are obnoxious to his own criticifm in the firft Interlude; they become unpleafing from being too diftinctly defcribed, with their kiffes and their baby hands. Perhaps the perfonified Moments are not lefs diftinctly pourtrayed in the

above 
above paffage from the Night Thoughts; but there, a penfive interefting morality cafts over them a foftening veil; while their gayer appearance and employment on the Darwinian page, brings them into glaring, and perhaps almoft ludicrous view.

That unpleafing change, which takes place in the Helleborus after impregnation, produces, in it's metamorphofis, a fair nymph, fuddenly fmitten by a loathfome diftemper, which utterly deftroys her charms. An odd comparifon enfues, the fuppofed actual transformation of Nebuchadnezzar into a beaft; whereas the Scripture only fays, that he dwelt with the beafts of the field, and took their prone habits. His imputed change into their Shape is ingenioufly, but fomewhat ludicroufly painted; and we are apt to fancy: the Euphrates flandered in thefe lines, which finely defcribe a river of Aluggith and fullied current : 
Lolls his red tongue, and from the reedy fide Of llow Euphrates laps the muddy tide.

That harmoniounly-named river of the Eaft, has too long rolled through our imagination in beautiful and lucid currents, for us to like this reverfe picture of it's ftreams. One of our poets, probably Milton, has fomewhere faid,

- and by the verdant fide Of palmy Euphrates.

At laft, fince the fituation of Babylon was certainly flat and marfhy, Dr. Darwin is probably correct in this inftance, however obftinately our fenfations may refufe to grant that one of the rivers which encircled Paradife can deferve to be fo defcribed; but there, as it was nearer it's fource in the mountain Niphates, it would certainly be more pure; befides, that it may be fuppofed to have become polluted 
by it's progrefs through lefs hallowed earth. The laft line of the Nebuchadnezzar-tranfformation is burlefque, by reafon of the epithet pendant :

Nor Flattery's felf can pierce his pendant ears.

And the alliterating $p$, makes the found of the line difpleafing as is the image it conveys.

The Menifpernum, Indian-berry, which intoxicates firh, being of the clafs two females, twelve males, here affumes the form of two Sifter Nymphs, fcattering their incbriating berries on the waters. The Popifh legend of St. Anthony preaching to the fifl, and converting them to Chriftianity, forms the whimfical and not very pleafing illuftration. It's language violates the third commandment deplorably.

The Papaver, Poppy, becomes a drowfy. Enchantrefs of malignant operation; but her 
her fomniferous palace is defcribed in thefe Tovely numbers:

Sopha'd on filk, amid her charm-built towets,

Her meads of afphodel, and amaranth bowers, Where Sleep and Silence guard the foft abodes,

In fullen apathy, Papaver nods.

Faint o'er her conch, in fcintillating freams, Pafs the light forms of Fancy and of Dreams.

Her enchantments are poetically given from old Tales of the Genii, and the is compared to Hermes driving the Ghofts to the thores of Erebus; and again his employment to the drawings of Mifs Emma Crew, a compliment of very forced introduction.

The Ciftus, a plant whofe tranfient, but plenteous fowers expand in fuccelfion on the firft warmth of May, becomes a Nymph, who calls her train to choir the birth of that month. She is obeyed, and a very exquifite fong enfues, in which the altercd meafure relieves the ear. Without wis 
any perceivable chain of thought, the fudden death of the fair Cifta, ferves to ufher in a fine picture of an hoar-froft landfcape, diffolving inftantaneoufly beneath a change of keen to foft wind, accompanied by the emerging fun.

Cinchona, Peruvian bark tree, paffes before us as a Peruvian Maid, on her way to the altar, which, in Quito, the had raifed to the goddefs Hygeia, and of which the is the adminiftrant priefters. Her progrefs thither, and her ceremonies at the fhrine, and her prayer to the Goddefs, are beautiful; the perfonified Difeafes fublime, particularly Ague. The accidental manner, in which, it is well known, the medicinal virtues of the bark were firft difcovered, is here conveyed to the reader with the happieft ingenuity, as a dictate of Hygeia to her Prieftefs, in anfwer to the prayer. Cinchona is commanded to yield her facred forefts to the axe, and to ftrew their

2 , bitter 
bitter foliage on the rivers. She obeys; her lovers fell the trees, and impregnate the waters with the leaves, while pale infected fquadrons kneel on the margin, and health and bloom return as they drink. All this forms a complete and charming little drama. It needed no illuftration, but it has a very ferious one, that of Mofes in the Wildernefs, ftriking the rock, "fo that "the waters flowed out."

To the bark-metamorphofis fucceeds that of the Digitalis, Fox-glove, of whofe now experienced, though not infallible virtue, in dropfical cafes, Dr. Darwin claims the firft difcovery. The bloated and cadaverous form of Dropfy appears, and his unquenchable thirft is compared to that of Tantalus in thefe four admirable lines:

So bends tormented Tantalus to drink, While from his lips the refluent waters fhrink;

Again the rifing ftream his bofom laves, And thirft confumes him 'mid circumfluent waves. 
Hygeia affumes the form of Digitalis; waves over the difeafed herferpent-wreathed wand, " and charms the thapelefs monfter " into man."

To her is compared the good Bifhop of Marfeilles, when the plague raged in that city; alfo the generous and active Mayor of London, when London was under fimilar vifitation. From him the Poet fides into a moft animated contemplation of the great Howard's virtue, and afferts that the rays of philantrophy.

Dart round the globe from Zembla to the Line;

O'er each dark prifon plays the cheering light, As northern luftres o'er the vault of night;

From realm to realm, by crofs or crefcent crown'd, Where'er mankind and mifery are found, O'er burning fands, deep waves, or wilds of fuow, Thy Howard, journeying, feeks the houfe of woe; Down many a winding ftep to dungeons dank, Where angui $\mathrm{h}$ wails, and galling fetters clank; To caves beftrew'd with many a mouldering bone, And cells, whofe echnes only learn to groan; Where no kind bars a wbifpering friend difclofe,

No fun-beam enters, and no zephyr blows, 
He treads inemulous of fame or wealth,

Profufe of toil, and prodigal of health ;

With foft perfuafive eloquence expands

Power's rigid heart, and opes his clenching hands;

Leads ftern-ey'd Juftice to the dark domains,

If not to fever, to relax the chains;

Or guides awaken'd Mercy through the gloom, And thows the prifon fifter to the tomb;

Gives to her babes the felf-devoted wife,

To her fond hurband, liberty and life!

The fpirits of the good, who bend from high, Wide o'er thefe earthly fcenes, their partial eye, When firft, array'd in Virtue's pureft robe, They faw her Howard traverfing the globe; Saw round his brow the fun-bright glory blaze In arrowy circles of unwearied rays, Miftook a mortal for an angel gueft, And afk'd what feraph-foot the earth impreft. Onward he moves, Difeafe and Death retire, And murmuring Demons hate him, and admire.

\section{If praife for a fingle verbal beauty may} not degrade the exalted merit of the above quotation, the biographer would obferve that it's word inemulous has a fweet effect, and that, the believes, it is there in firft coinage. 
coinage. Unambitious, the word in common ufe for that meaning, is comparatively hard and cumbrous in verfe.

This citation conftitutes far the fublimeft eulogy by which Poetry has immortalized the matchlefs Howard, Mr. Hayley's noble Ode alone excepted. That was the carlieft tribute to his high worth, and it is admirable in a degree which only Darwin has equalled, and which perhaps no Poet can excel.

The Gnomes now fufpend the again filent lyre on the thrine of Hygeia; the Sylphs flacken the ftrings, and catch the rain-drops on their hadowy pinions, while a Naiad prepares the tea-urn. The lait Canto clofed with a Mower. That it Thould rain alfo in the termination of this, is a famenefs which furprifes us from an imagination fo various. Then furely there is too ftrong a contraft between the folemn and dignified praife of Howard, immedi-

$$
\times 4
$$

ately 
ately preceding, and the light and frolic idea which places a Mufe, the recent Hiftorian of virtue fo truly great, at the teatable! It is out of keeping, as the painters fay.

We meet ingenious and juft criticifm in the Interlude to this fecond Canto. A ware of the frequent want of evident refemblance between his fubjects and their fimilies, Dr. Darwin fhelters himfelf under the authority of Homer, which perhaps will not entirely fecure his practice from cenfure, fince, if Homer's fimilies do not often touch the object with which they are compared, at all points, yet are they never fo utterly without connexion with it, as feveral which may be found in this poem. That a poetic fimile fhould not be precife in it's refemblance is certain, at leaft that it is the more fublime, or more beautiful, for not quadrating exactly; yet it ought to poffefs fuch a degree of affinity with the fubject, 
fubject, that when the theme and it's illuftration are viewed together, we may feel, though we cannot verbally demonftrate the perfect juftnefs of the fimilitude.

Thus, in general, are the fimilies of Homer conftructed, and thus Milton's, feveral of which, in the Paradife Loft; are grander than moft of thofe in the lliad and Odyffey. A deceafed modern Poet has given one of extreme beauty, which, from it's aptnefs without precifion, bears exactly that relation to the object it illuftrates which a poetic fimile ought to bear. There is no obvious connexion between our idea of youthful beauty, paled and thadowed over by death, and a vernal dayfpring, which rifes cold and rainy :

Her facc was like an April morn Clad in a wintry cloud:

yet when Poetry connects them, we are immediatcly fenfible of their interefting affinity, 
affinity. Death itfelf cannot at firft conceal, however it may fhroud the traits of youth, and of what once was lovelinefs; neither ean the dull $\mathrm{fky}$ and nipping wind prevent our perceiving the youth of the year, when April has put forth her frefh grafs and verdant fprays.

In the courfe of Dr. Darwin's fecond Interlude, there is fine difcrimination between the tragic and the difguftingly horrid; and his cenfure of the painters for their frequent choice of difagreeable fubjects for their pencil, fuch as torture and carnage, is perfectly juft.

\section{THIRD CANTO.}

From the penfive graces of this exordium refult extended ground of cenfure for the undignified fituation of the Mufe at the clofe of the fecond Canto; fince her modern Tea-table is here converted into a graffy throne, bedewed with tears, around whick 
which float the thin forms of Sorrows and Apprehenfions, of Sighs whifpering to the chords of her lyre, and Indignations, half untheathing their fwords. Thefe fame Indignations are new allegoric perfonages, and may be of dubious welcome. The Paffions, with fwords by their fides, form invagery which is liable to give a ludicrous impreffion; yet we hould remember, that Milton puts a fword into the hand of the archangel, Michael, in the 6 th book of the Paradife Loft, and Pope into that of a Ghoft in his Elegy to the Memory of an unfortunate Lady ; but Milton gives the weapon dignity by invefting it with flames, on the authority of Scripture, and Pope foftens off the literality by it's imputed indiftinetners, and by the epithet vifronary. " Why " dimly gleams the vifionary fword ?"

Circea, Enchanter's Nighthade, is the firft transformation in this Canto. We learn from the note to the paffage, that 
it grows among the mouldering bones and decayed coffins of Sleaford Church, Licolnfhire, and that it was celebrated in the myfteries of witchcraft, and for the purpofe of raifing the devil.

As the Tremella is the mort beautiful, fo is Circea the fublimeft transformation of the four Cantos. Her marriage with the two Fiends; it's portentous figns which precede the fatanic nuptials; the fcream: ing bats, the owls, and the dog of midnight howling the epithalamium; the burfting ground; the afcending Demons; their progrefs with the grim Bride to the violated temple; thofe hapelefs fpectres, which, by glimpfes of the moon through the coloured glars, are feen to quiver on the walls, as Circea and her horrid bridegrooms pafs along the ailes, that difmally echo their fteps; the unbleffed wine with which they pollute the chalice; their hideous laugh which 
which difturbs the filence of the choir; and the impious mummery of the nuptial rites; all thefe circumftances were conceived, and are expreffed with prodigious ftrength of fancy.

The Laura-cerafus, twenty males, one female, appears next, as the Pythian prieftefs * delivering her oracles. This is her grand portrait :

Avaunt ye vulgar! from her facred groves,

With maniac ftep, the Pythian Laura moves;

Full of the God her labouring bofom fighs,

Foam on her lips, and fury in her eyes,

Strong writhe her limbs; her wild dihevell'd hair

Starts from her laurel wreath, and fwims in air,

While twenty priefts the gorgeous thrine furround,

Cinctur'd with ephods and with garlands crown'd,

Contending hofts, and trembling nations wait

The firm immutable behefts of fate;

She fpeaks in thunder from her golden throne,

With words unwilld, and wifdom not her own.

* The Pythian prieftefs is fuppofed to have been made drunk with the infufion of laurel leaves, when the delivered het oracles. The intoxicatior, or infpiration, is finely defcribed by Virgil. 
To the Pythian Laura is compared the diftrefs of a beautiful nymph in flumber, beneath the influence of the night-mare. It is a poetic picture after Fufeli. The fquab and grinning Fiend, as he fits on the bofom of the fleeping Maid, and his mooneyed mare, looking in through the bedcurtains, are pictures of ludicrous horror. They are drawn with rival ftrength by the Poet and Painter; and are contrafted by the lovely form of the agitated flumberer; but the fucceffion of her convulfive appearances which the Poet brings to the eye, affords another inftance of the fuperior power of the pen to that of the pencil, when each are directed by the impulfe of true genius.

The perfonification of the Indian figtree is made a vehicle of introduction for the fcenery of Dovedale and Hlam, the cave of Thor, the Saxon God, and all the fanguinary fublimities of his druidical rites. 
The only connexion between the fubjeat and it's illuftration is, that " each branch " of the large fig-tree of India, emits a "flender, flexile, depending appendage " from it's fummit, like a cord, and which "roots into the earth, and rifes again; " and the Hamps and Manifold, rivers of " the Dovedale vicinity, in their courfe " over a romantic moor, fink fuddenly " into the earth, and rife again in Ilam " gardens, after their fubterranean paffage " of three miles."

Impatiens, Touch-me-not, from the peculiar nature of the plant, and the elaftic motion by which it throws it's feeds to a great diftance, has, in it's transformation, fufficient affinity to the ftory of Medea, here introduced as it's fimile. Nowhere is that friking poetic legend fo finely told. The paffions of jealoufy and defpair, excited by the mercenary ingratitude of Jafon, are here painted in their ftrongeft colours, rifing 
rifing in power and force, till the dire filiacide clofes the epifode.

Thofe electrical properties of the Dictamnus, Fraxinella, afferted by Dr. Darwin as having witneffed them in the ftill fummer nights after long draught, induces him to transform her alfo into an enchantrefs, and the hour and feafon in which the celebrates her magical rites, is thus fweetly fpecified:

What time the Eve her gauze pellucid fpreads

O'er the dim flowers, and veils the mifty meads,

Slow o'er the twilight fands and leafy walks,

In gloomy dignity, Dictamna ftalks.

The deleterious tree, the Mancinella : the Urtica, Englin nettle, and the Lobelia longiflora, a deadly plant of the Weft Indies, form a continuation of Enchantreffes, and their metamorphofe is attended by ftill darker traits of demonifm. As the firft and laft of thefe three vegetables have life-deftroying properties, and the Englifh nettle only intlicts a llight and tranfient pain, the ought 
ought not to have appeared in fuch company. Her comparative infignificance is that of a wafp between a cobracapella and a rattle-fnake. The ruins of Palmira are defcribed as a fimile to the mifchiefs of the four preceding witches, but why or wherefore defies all poetic guefs; however, the fault of utter inconnection is atoned by the grandeur of this fombre picture.

To that fucceeds the embrutality of the Upas Tree, now fuppofed to be of fabulous exiftence. It is preceded by a beautiful landfcape of the Ifle of Java, in the centre of which this dreadful tree was afferted to have ftood. The feas of glafs, the noble rocks, the ever-fummered gales, and the fylvan graces which zone that large ifland, form an exquifite contraft in this paffage, to the defolation round the Hydra Tree of Death, as it's author fublimely calls it. The Upas Tree becomes a terrific monfter under the wand of our potent magician. The 
enormous dragon is grand, with his unnumbered heads extending over ten fquare leagues, and with many infant ferpents growing out of him, like thofe of Sin in the Paradife Loft; a dragon, that

Looks o'er the clouds, and hiffes in the ftorm.

Into a monfter the Upas muft be made. This Poet's fyftem of vegetable animality would not permit it to remain in that fo much more impreffive though quieter horror, with which it is defcribed in the Dutch furgeon's narrative. A lonely tree by the fide of a rivulet, in a barren and ftony valley, circled round by vait and fterile mountains; no tree but itfelf! no hedge! no blade of grafs! no wing of bird! nothing that breathes to difturb the dreadful filence! dead bodies fcattered about the wafte in every various ftage of putridity; and the tree itfelf exhaling a vifible and poifonous vapor, inftantly fatal to every living 
living thing which breathes the air it taints within a diameter of fifteen miles! what furious dragon, even from the pen of Dr. Darwin, but lofes it's terrors before this ftill, this ghaftly defolation!

The profe narration, taken from the London Magazine, is inferted in the clofe of the additional notes to the Loves of the Plants. It has fuch an air of fimple veracity, that we do violence to our feelings when, on reflection, we refufe to give it credit. The gum of this tree is there afferted to be of high price, and ufed to envenom the Indian arrows; that it is procured by Criminals under fentence of death, who redeem their lives if they can bring from the Upas a box of it's gum; an experiment of immenfe hazard, fince the poffibility of returning depends upon the perpetually veering winds blowing a fteady gale towards the tree as the delinquent approaches it, in a progrefs of at 
leaft fifteen miles. The feldomners with which that happens, and the frequency of the attempt, ftrew the circumjacent t plains with the dead. Faith in this wonderful tale has melted away in fubfequent inquiry. Many have faid that Dr. Darwin certainly believed the account. He certainly writes as if he believed it; yet that was but to ferve a poetic purpofe; credulity was not one of his propenfities.

The Orchis Morio, the parent root of which fhrivels up and dies as the young one increafes, is transformed into a fond mother, nurfing her infant at the expence of her own health and life. This animation is fhort, and, compared to many of the others, has little intereft; but it's two illuftrations have every intereft, and the fecond forms a very fweet and mournful epifode. The firt is a lorely picture of a wounded deer, efcaping from her amburhed archer, and flying, with her fawn, to the woodlands, 
woodlands, over plains fpotted with her blood; and, amid thick thades, hanging over her young, and weeping her life away. Then, in fucceffive fimile, comes the thrice interefting ftory. An Officer's Wife with her infants, watching; from a near hill, the battle of Minden, in which her hurband was engaged, is mortally wounded by a random thot. We find this incident related with fo much pathos as almoft to diffipate the apprehenfion, that Dr.Darwin's rage for the picturefque would, in a fubject of genuine intereft for the human paffions, have proved deftructive to his powers of awakening them. The mournful truth of one line in this epifode ought: to fink deep in every human heart, viz.

The angel Pity fhuns the walks of War.

Truly honourable is it to the Poets of this reign, that the beft of them have never ftimulated, but; on the contrary, have endea- 
endeavoured to meliorate and abate that belligerent fpirit, always injurious to the true intereft of this country, and fruitful in the extreme of human mifery. A fpirit, by which Britain looks over the Atlantic, fhorn of her continental beams; a fpirit, to whofe unwarned and perfifting violence in later years, the lives of the foldiery, and the comforts of millions of families, were lavifhed in defiance of the Gorpel, which preaches peace on earth, and good-will towards men.

But to return to the epifode; the lifping boy, on his father's approach.

Speak low, he cries, and gives his little hand; Eliza fleeps upon the dew-cold fand; Poor weeping babe, with bloody fingers prefs'd, And tried, with pouting lips, the milklers breaft. Alas! we both with cold and hunger quake, Why do you weep? Mamma will foon awake! She'll wake no more! the haplefs mourner faid!

Nothing can be more natural and more affecting than the ideas in this fpeech of the 
the child, only that dew-cold and milkle/s. are not infantine expreffions.

The Cufcuta, Dodder, four males two females. It does not root itfelf in the earth, but afcends the regetables in it's neighbourhood, and ultimately deftroys the plant on which it had grown to maturity. In this fyftem of animality it is reprefented as two treacherous coquets, fmiling to betray; and, from the circumftance of the plant twining round the Ihrub or tree, which it finally kills, the ungrateful beauties are compared to the ferpents, which ftrangled Laōcoon and his fons. That ftory here forms a faithful poetic picture of the celebrated ftatue.

In the transformation of the Vine into a Bacchanalian Female, the Doctor introduces, and enforces his juft and favorite fyftem, of confidering the free ufe of vinous fluid, in all it's ftages, as the fource of our moft fatal chronic difeafes. They are very

$$
\text { z } 4 \text { poetically }
$$


poetically imperfonifed as they hover round the feductive nymph, Vitis, while Chemia mingles poifon in her bowl. This fell group is admirably illuftrated by an image of Prometheus chained to a rock, with a vulture devouring his liver. The many diforders of the liver, fo torturing and fo fatal, which ebriety caufes, are nobly allegorized in this fable of him, who is reprefented as being thus punifhed for having ftolen fire from heaven. Dr.Darwin's note to this paffages deferves to be engraven on every man's memory, fince it is the atteftation of a great Phyfician, founded on an extenfive, practice of nearly half a century.

The Cyclamen, Shewbread or Sowbread, which, "when it's feeds are ripe, gradually "6 twifts it's ftalk fpirally downward, till it 66 'touches the earth, and there inferts it's " offspring," is changed into a tender matron, refigning her departed infants to 
the grave, and breathing a pious hope of their refurrection. The fimile on this ocfion is perhaps the fublimeft paffage in the whole work; it's real, and, in former ages, often exifting horrors, tranfcend in ftrength all Imagination has formed, or can form, with her train of fpectres, witches, and demons :

So when the Plague, o'er London's gafping crowds, Shook her dank wing, and fteer'd her murky clouds; When o'er the friendlefs bier no rites were read, No dirge flow chanted, and no pall outrpread; While Death and Night pil'd up the naked throng, And Silence drove their ebon cars along, Six * lovely daughters, and their father, fwept To the throng'd grave, Cleone faw, and wept. Her tender mind, with meek religion fraught, Drank, all-refign'd, Affliction's bitter draught;

* During the laft great plague in London, one pit, to receive the dead, was dug in the Charter Houfe, forty feet long, fixteen feet wide, and twenty feet deep, and in two weeks received 1114 bodies. During this dire calamity there were inftances of mothers carrying their own children to thofe public graves; and of people delirious, or in defpair for the lofs of friends, who threw themfelves alive into thefe pits. See Journal of the Plague in 1665, printed for E. Nutt, Royal Exchange. 
Alive, and liftening to the whifper'd groan Of other's woes; unmindful of her own.

One fmiling boy, her laft fweet hope, the warms,

Hufh'd on her bofom, cradled in her arms.

Daughter of woe! ere morn, in vain carefs'd,

Clung the cold babe upon thy milklefs breaft

With feeble cries thy laft fad aid requird,

Stretch'd it's fiff limbs, and on thy lap expir'd!

Long, with wide eye-lids, on her child the gaz'd,

And long to heav'n their tearlefs orbs the rais'd;

Then, with quick foot and throbbing heart, the found

Where Chartreufe open'd deep his holy ground;

Bore her laft treafure through the midnight gloom, And kneeling dropp'd it in the mighty tomb.

"I follow next !" the frantic mourner faid, And living plung'd amid the feftering dead.

It appears to the author of this memoir, that, in the above folemn, great, and impreffive epifode, only two words, an epithet and it's fubftantive, " ebon cars," could be changed to advantage. Ebony has a gloffy and polifhed black, and is therefore of unfuitable refemblance to that vehicle of horror. Then amid the dreadful truths of the defcription, 
defcription, the dead cart thould have been called by it's fimple name; car, has a fine triumphant found, which fomewhat difturbs the awful horror of the impreffion. Surely the vehicle without nominal alteration, and with a ftronger epithet prefixed, that fhould not fpecify it's complexion, would be better,

While Death and Night pil'd up the naked throng. And Silence drove their ghaftly carts along.

From the banks of the Ontario we have the Caffia. It is one of thofe American fruits which are annually thrown on the coaft of Norway, in wonderful emigration. Dr. Darwin accounts for it by a fuppofed exiftence of under currents in the depth of the ocean, or from vortexes of water paffing from one country to another through caverns of the earth. The Caffia, ten males one female, is reprefented as a fair American matron, who, alarmed by the 
rifing tempert, trufts her children to the floods. The Scripture tradition of Mofes, committed to the Nile by his Hebrew mother, is here told with aptnefs to the fubject, with picturefque beauty, and with pathetic fweetnefs. This child, refcued from the flood, and rifing into an ambaffador of Heaven, a mighty Prophet, that wrefted the fcourge from the oppreffor's hand, and broke the iron bonds of his nation's flavery, nobly and religiounly clofes the paffage; and in that clofe awfully contrafts the tendernefs of the opening. From thence the Poet paffes into another fublime philippic on the plague-fpot in the moral and religious health of Britain, her cruel Slave Trade, and makes this friking appeal to our fenators :

E'en now, e'en now, on yonder weftern thores, Weeps pale Defpair, and writhing Anguith roars :

E'en now in Afric's groves, with hideous yell, Fierce Slavery ftalks, and Nips the dogs of hell ; 
From vale to vale the gathering cries rebound, And fable nations tremble at the found!

Ye bands of fenators, whofe fuffrage fways Britannia's realms; whom either Ind obeys; Who right the injur'd, and reward the brave, Is Stretch your frong arm, for ye have power to fave !

-Thron'd in the vaulted heart, his dread refort, Inexorable Confcience holds his court;

With ftill fmall voice the plots of guilt alarms, Bears his mank'd brow, his lifted hands difarms; But wrappd in night, with terrors all his own, He fpeaks in thunder when the deed is done. Hear him, ye fenates! hear this truth fublime, He who allows oppreffion, thares the crime.

No radiant pearl, which crefted Fortune wears, No gem, that fparkling hangs from Beauty's ears; Not the bright ftars which night' 6 blue arch adorn; Not rifing funs that gild the vernal morn, - Shine with fuch luftre as the tear, that breaks, For other's woe, down Virtue's manly cheeks.

So admirably does this Bard drop the curtain of moral truth and humanity over the tiffues of his fancy, in this the grandeft of his fecond-part Cantos. The Mufe of Botany now retires with much 
much more ferious grace from her choir than the had done in the preceding Cantos, and it becomes her well, from the more fombre nature of it's recent themes.

Alike ingenious and juft are the critical obfervations with which this third Interlude commences; they are on the relation between the arts of Poetry and Painting. In the progress of it's ftrictures Dr. Darwin has not fucceeded fo well. When he would eftablifh affinity between the meafures of metrical and mufical compofition, it was owing to his total want of knowledge in mufical fcience that he is vifionary, abftrufe, and incomprehenfible. The inStances he gives of fancied triple and common time in our verfe, by no means fupport his theory, after all the pains which can be taken to comprehend it by thofe who underftand both the arts. His fuggefted poflibility of luminous harmony, accordant to that which is vocal, feems metaphyfical 
in as wild extreme as the fuppofed analogy between the meafures of poetry, and the time of mufic, had been unfuccefsfully mathematical.

A pleafing inftance of paternal eulogy occurs in this Interlude concerning the ingenious difcovery on the harmony of colours, by Dr. Darwin of Shrewrbury. The demonftrated exiftence of that harmony gives, as our Poet juftly obferves, Mufic. and Painting undoubted right to borrow metaphors from each other; "Muficians, " to fpeak of the brilliancy of founds, and " the light and Thade of a concerto; and "Painters, of the harmony of colours and " the tone of a picture;" but, when he feeks to extend in our fenforium thefe real affinities between the nature of colours and of mufical founds, into an equal relationfhip between the poetical and the mufical meafures, he becomes incomprehenfible to thofe who know the nature of 
each too well to believe it poffible that the mechanical divifions of mufical time have their correfponding rules in the formation of Englifh verfe, whether blank or in thyme. Perhaps the fyftem may, as he afferts, extend to the poffibility of fetting pictures, as well as verbal expreffions, to mufic, but not, furely, as Dr. Darwin fuppores, with better effect than when mufic is adapted to the fentiments or the imagery of verfe. The love of novelty only could have induced fuch a preference. 'It is conceivable that a picture, whether hiftoric or fcenic, might be exhibited while fuch harmonic ftrains are played by a band, as fiould well exprefs the paffions and feelings of the hiftoric group before us, or the particular character of the landfcape; but as the picture has only it's moment, fo muft the correfponding melody and harmony of inftruments have only one ftrain; no fucceffive and contrafted movements.

Poetry 
Poetry and Mufic are both progreffive, Painting is fationary, therefore the natural union is between the two firft; and pictures can be worth nothing to the mufician in his imitative art, in comparifon with poetry, whofe paffions and fcenes are changeful, often contrafted, and always proceeding.

Again, the poetic Critic emerges into truth and day-light, when he compares the nature and privileges of the Greek and Latin languages with thofe of our own. Silent about the tones of each, where fuperiority is univerfally confeffed to be with the two former, he proves that the conftitution of the Englifh language is, from it's power of more varioufly compounding it's terms, and from it's greater facility in producing perfonifications, better calculated for poetry than the Greek and Latin. Accordingly, our poetry has more imagery than that of either of thofe languages. From this comparifon the author flides into the 
fubject of plagiarifm from the Ancients, and from former Bards of this nation. He diftinguifhes well what is, and what is not amenable to that cenfure, and acknowledges the few paffages of borrowed ideas in the three preceding Cantos. He fays, "Where the fentiment and expreffion are " taken from other writers without due " acknowledgment, an author is guilty of " plagiarifm, but not on the teftimony of " fingle words and cafual phrafes;" and adds, "they are lawful game, wild by " nature, the property of all who can " capture them. Perhaps a few common " flowers of fpeech may be gathered as "We pafs over our neighbour's ground, " but we muft not plunder his cultivated " fruit." Dr. Darwin forgot that juft reftraint when he took, unacknowledged, forty-fix entire lines, the publifhed verfes of his friend, for the exordium of the firft part of his work. That extraordinary, and 
in a Poet of fo much genius, unprecedented inftance of plagiarifm excepted, not one great Poet of England is more rriginal than Darwin. His defign, his ideas, his ftyle, his manner, are wholly his own.

"Bright forms that glitter in the Mufe's ray,

"With orient hues, r nborrow'd of the fun."

\section{FOURI'H CANTO}

Opens with a fun-rife and a rain-bow, each of Homeric excellence. The Mufe of Botany gazes enchanted on the fcene, and fwells the fong of Paphos to fofter chords. Her Poet adds :

Long ailes of oak return'd the filver found,

And amo rous Echoes talk'd along the ground.

This is almoft verbatim from Pope's line,

And more than Echoes talk along the walls.

Plagiarifm is atoned when it improves upon it's original, and that is always to be 
expected from genius rich as Dr. Darwin's; but in the prefent inftance we are difappointed. This generally fo very accurate defcriber, here indolently facrifices the verifimilitude of the circumftance, rather than change his rhymes. Echoes talk in the air and along walls but we never hear their voice at our feet. They are there in double inaccuracy, fince if the oaken viftas returned the found, that found is echo; fo we have firft a literal echo, and, immediately after, a plurality of perfonified echoes creeping on all four, and telling their imitative tales where no "Nymph of the airy " cell," as Milton beautifully terms the echo, ever deigned even to whifper.

\section{Suppofe,}

Long ailes of oak the filver founds retain, And all their echoes breath'd the amorous ftrain.

Dr. Darwin proceeds to recall his readers to the local fituation of his Mufe : 
Pleas'd Lichfield liften'd from her facred bowers,

Bow'd her tall groves, and fhook her flately towers.

The firft transformation of this Canto is the Cereus grandiflora, of Jamaica, twenty males one female. It flowers and becomes odoriferous during a few hours in the night, and then clofes to open no more. The Cerea becomes a Maid of Night, contemplating it's "ftellar funs:" and the is compared to the Fairy Queen of Mr. Mundy's Poem, Needwood Foreft, in a lovely ftrain, defcriptive of the Elfin Sovereign. Of fuch a pleafing perfonage a fecond portrait is welcome. The reader may be gratified by comparing on this page the pictures of Titania from two Pocts of whom Staffordhire may be proud.

NEEDWOOD FOREST.

Hark the foft lute! along the green Moves, with majeftic ftep, the Queen. 
Attendant Fays around her throng, And trace the dance, or raife the fong;

Or touch the fhrill reed as they trip, With finger light and ruby lip.

High on her brow fublime is borne

One fcarlet woodbine's tremulous horn;

A gaudy bee-bird's ample plume

Sheds o'er her neck it's wavy gloom;

With filvery goffamer entwin'd,

Stream the luxuriant locks behind.

Thin folds of tangled net-work break,

In airy waves adown her neck;

Watp'd in his loom, the fpider fpread

The far diverging rays of thread.

One rofe-leaf forms her crimfon veft,

The loofe edge croffes o'er her breaft,

And one tranflucent fold, which fell

From a tall lily's ample bell,

Forms, with fweet grace, her fnowy train,

1. Flows, as the fteps, and fweeps the plain.

Silence and Night enchanted gaze,

And Hefper hides his vanquifh'd rays.

\section{BOTANIC GARDEN.}

Thus, when old Needwood's hoary fcenes the Night

Paints with blue fhadow, and with milky light;

Where Mundy pour'd, the liftening nympbs among,

Loud to the echoing vales his parting fong, 
With meafur'd fep the Fairy Sovereign treads,

Shakes her high plume, and glitters o'er the meads;

Round each green holly leads her fportive train, And little footfteps mark the circled plain;

Each haunted rill with filver voices rings, And Night's fweet bird in livelier accent, fings.

The next floral animation, the Tropoolum Majus, Garden Nafturtion, eight males one female, is introduced by thefe lovely lines:

Ere the bfight Star which leads the morning fky

Hangs o'er the milky Eaft it's diamond eye,

The chafte Tropoe leaves her fecret bed;

A faint-like glory trembles round her head;

alluding to the "electric flafhes, which " Mifs E. C. Linneus firft obferved about "this flower in a fummer morning, before " fun-rife." A plenty and pomp of illuftration is allotted to this flower; firft the fire-fly of the tropics; next the ignis-fatuus, which Dr. Darwin had deemed fabulous; and laft the intrepid Youths of Judea, con-

$$
2 \text { A } 4 \text { demned }
$$


demned by Nebuchadnezzar to the burning fiery furnace.

With fublime fimplicity has the Prophet

Daniel told that ftory. Beneath every remembrance in favor of the infpired hiftorian, we are here impreffed and charmed anew by grandeur of imagery and picture, fuited to the miraculous greatnefs of the fcene. We again behold the blazing deluge, the fiery cavern, white with fevenfold heat; the three Heroes in the midft:

And now a fourth, with Seraph-beauty bright, Defcends; accorts them; and outfhines the light, Fierce flames innocuous, as they ftep, retire, And flow they move amid a world of fire!

How beautiful is the latter part of the fecond line!

The Avena, Oat, three males two females, becomes a pair of mufical nymphs; alluding to the oaten pipes of early times, perhaps the firft invented inftrument of the 
harmonious fcience. The fifter 'Avenas fing a lovely paftoral ballad, whofe fhorter meafure again, as twice before, in the courfe of this poem, agreeably relieves the ear.

Cannabis, Chinefe Hemp, is introduced by this fine appropriate landfcape, where

China,

O'er defert fands, deep gulphs, and hills sublime Extends her maffy wall from clime to clime; With bells and dragons crefts her Pagod-bowers, Her filken palaces, and porcelain towers; With long canals a thoufand nations laves, Plants all her wilds, and peoples all her waves; Slow treads fair Cannabis the breezy ftrand, The diftaff ftreams diRhevell'd in her hand.

The female form is always attractive from the poetic pencil of Darwin. Even the homely diftaff becomes elegant, as in the hand of a fair Nymph, it's flax is buoyant on the gales of morning. Cannabis proceeds in her fpinning, and the Graces hover around her wheel; yet to her is "ftern Clotho" compared, who weaves 
the web of Human Deftiny, "the cradle " and the coffin binding it's ends;" but the Lady is here in her kindeft mood, aufpicious Fortune turning the giddy wheel ;

But if fweet Love, with baby-fingers, twines,

And wets, with dewy lips, the lengthening lines,

Skein after fkein celeftial tints unfold, And all the filken tiffue fhines with gold.

Galanthus Nivalis, Snow-drop, fix males one female, is introduced as a delicate and fprightly lady, playing amidft a wintery fcene of filent floods, white hills, and glittering meadows. She chides the tardy Spring, and commands the Weft Wind to ftretch his folded pinions. She awakens the hoarfe Cuckow in his gloomy cavern, calls the "wondering Dormoufe from his temporary grave ; bids the mute Redbreaft enliven the budding groves, and the plighted Ringdove rcoornthe Redbreaft, however, is not mute amidl the hybernal filence of nat ife, the warbles on the hoary fpray. 


$$
\text { DR. DARWIN. }
$$

Bellis Prolifera, Hen and Chicken Daify, next becomes an affectionate matron, furrounded by her happy infants. Their childifh fports, with the infects of the advanced Spring, and with the harebells and primrofes, form a domeftic fcene of tender and lively intereft. In the courfe of it a compound epithet for the Snail brings that reptile inftantly to the eye :

Admire his eye-tippd horns and painted mail ;

alfo, by the adverb, paufing, "the paufing " butterfly," is that gay infect recalled to us on it's airy evolutions. Venus and her Loves making arrows for Cupid in Vulcan's forge, is given as a fimile to that fcene; if fimile it may be called which fimilitude has none. However, the mechanifm of bow and arrow-making is prefented with very amufing precifion.

Evidently to fupport a fplendid prelufive defcription of Matlock, and the theory of the 
the warmth of it's fountain proceeding from internal volcano, is the aquatic plant, the Fucus, introduced, which, we are told, foon appears in all bafins that contain water. The Fucus is reprefented as a beauteous youth, who bathes his fair forehead in the ftreaming fountain. The fcriptural Angel who thook his plumes over the pool of Bethefda, illuftrates the Fucus, prefiding over the falubrious fprings of Matlock. This fimile has much propriety, fince Dr. Prieftley informs us that " great quantities of pure dephlogifticated " air are given up in water at the points " of the Fucus, particularly in the fun" Mhine, and that hence it contributes to "preferve the water in refervoirs from " becoming putrid."

Trapa, four males one female, another aquatic plant, comes before us; thus,

Amphibious Nymph, from Nile's prolific bed Emerging Trapa, lifts her pearly head. 
Fair glows her virgin cheek and modeft breaft, A panoply of fcales deforms the reft;

Her quivering fins and panting gills the hides, But fpreads her filver arms upon the tides; Slow as the fails, her ivory neck the laves, And thakes her golden treffes o'er the waves.

Charm'd round the Nymph, in circling gambols glide Four Nereid forms, or thoot along the tide; Now, all as one, they rife with frolic fpring, And beat the wondering air on humid wing; Now all defcending plunge beneath the main, And lafh it's foam with undulating train; Above, below, they wheel, retreat, advance, In air and ocean weave the mazy dance;

Bow their quick heads, and point their diamond eyes, And twinkle to the fun with ever changing dyes.

\section{By this picture we are reminded of the} figure of Sin at the gates of hell.

The one feem'd woman to the waif, and fair,

But ended foul in many a fcaly fold,

Voluminous and vaft!

Milton's Paradife Loft.

The enfuing transformation conveys us from the flat thores of the Nile to the bafe of the Andes. The plant is the Ocymum Salinum, 
Salinum, Saline Bafil, two males two females. She is complimented with chaftity as having but one lover. Her fituation prefents a fine landfcape, and her form is arrayed in every feminine and modeft attraction. The fpray of ocean bathes her delicate limbs, uncurls her amber-hued treffes, and encrufts her perfon with faline films, through which, as from amidit a fhrine of cryftal, her beauty beams. To this faline plant belongs a note extremely worth the attention of the reader, fince it contains an opinion of univerfal medical importance, from one of the moft difcerning phyficians which perhaps the world has produced. It relates to, by him, fuppofed pernicious effect of too free indulgence in that moft agreeable of all the artificial taftes, the love of falt with our food. The transformation of the Ocymum Salinum brought to the Poet's memory the unfortunate wife of Lot, whofe ftory is 
here told with great and pathetic beauty. Herfelf and hufband are compared to Orpheus and Eurydice, to IEneas and Creufa. The ftory concludes with a fine verfification of the fcriptural picture of the tuins of Sodom and Gomorrah. Perhaps it will be found fomewhat inferior to Mafon's paraphrafe of the defolation of Babylon: The reader will compare the paffages, and judge for himfelf.

\section{BOTANIC GARDEN.}

Oft the lone Pilgrim, that his road forfakes,

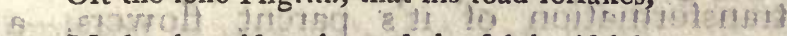

Marks the wide ruins and the fulphur'd lakes;

On moulderit'g piles, amid afphaltic mud, il misl "

(15) Hears the hoarfe Bittern where Gomorrah ftood s I is

Recalls th' unhappy pair, with lifted eye,

Leans on the cryftal tomb, and breathes the filent

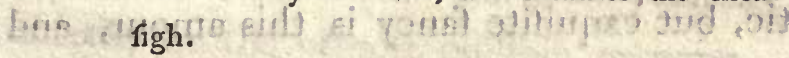

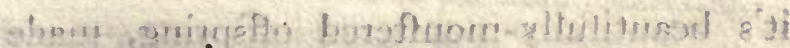

MASON'S ODE ON THE FATE OF TYRANNY.

Where yon proud Gity ftood

Now fpreads the ftagnant mud;

And there the Bittern in the fedge 'fhall lurk,

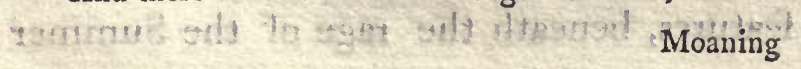


Moaning with fullen ftrain,

While fweeping o'er the plain,

Deftruction ends her work.

Arum, of the clafs Gynandria, or mafculine ladies, becomes an Amazon, in the modern military garb, and it's appendages. Dejanira exchanging her diftaff for the lion-fpoils of her mighty lover, illuftrates the Haram in a beautiful poetic picture.

The mule-flower, produced from the union of the Dianthus Superbus, Proud Pink, and the Caryophillus, Clove, produces, in the transformation of it's parent flowers, a whimfical but highly ingenious comparifon to the Perfian fable of the amours of the Nightingale and the Rofe. With romantic, but exquifite fancy is this amour, and it's beautifully-monftered offspring, made out. That curious plant, the Chundali Borrum, whofe hiftory and ftrange habits are defcribed in a note to the paffage, is preceded by an African landfcape of fublime features, beneath the rage of the Summer 
Solftice, and the poifonous breath of the Harmattan, the only gale that flits over the tawny hills. Gafping panthers are rolling in the duft, and dying ferpents are writhing in foamy folds; the woods on Atlas, blafted by the heats, and the waters of the Gambia Ahrinking in their channels; Ocean rolling to land his fick hoals, and Contagion ftalking along the fhore. Amid the fultry wafte rifes the graceful nymph, Chunda, with her brow unturbaned, and with loofened zone. Her ten lovers are employed in mitigating for their fair miftrefs the ardors of the climate, with the umbrella and the fan.

Of equal excellence, a Greenland pieture contrafts, in the utmoft poffible extreme, the preceding landrcape. A daylefs horizon, ftreaming with the milky light of the Aurora Borealis, and all the white mountains gleaming to the moon; Bears ftalking, flowly over the printed fnows; and vaft 
ribs of ice, burfting with the noife of loud . eft thunder. Then is fhown the vernal diffolution of this feene, beneath the rifing of the pale, fix-months day; and the Mufchus, Coral-Mofs, in the form of an Arcticregioned lover, awakens his Fair One, and defcribes the fy mptoms of returning Spring:

The lake and fea-plant, Aga, Conferva Egagropila, is next introduced by this beautiful line,

Night's tinfel beams on fmooth Loch-Lomond dance,

Where the charms of poetic found are felt, that is one of the lines which, after perufal, takes poffeffion of the memory, and lingers on the ear. We are told, in a note, that this regetabie is found loofe in many lakes; that it is of a globular form, from the fize of a walnue to that of a melon; does not adhere to any thing, but rolls from one part of the lake to the other. Here it becomes a fair maid, fitting on the banks of LochLomand, 
Lomond, expecting her lover to fwim to her from the centre of the water, and exploring, with anxious eyes, every paffing wave. Since a number of aquatic plants had been previounly humanized, it is probable this is indebted for fuch diftinction to the inclination of the Poet to retell the celebrated ftory of Hero and Leander, after Ovid. As a fimile it is perfectly comparative to the defcribed fituation and folicitude of Æga. Dr. Darwin was confcious of dis rarely-equalled talent in defcriptive ftory; of his power to bring objects full and diftinet on the reader's eye, by attitudes, looks, and employments, peculiar to their fituation. Ovid fays, Hero hung her lamp in a tower which overlooked the Hellefpont, that her lover, as he fwam acrofs the flood, might fee to fteer his courfe by it's light. The art of glafs-making, unknown in thofe times, the danger of the lamp being blown out muft have been imminent. 
imminent. It is therefore natural that Hero fhould affiduoufly ftrive to guard it from the wind. Of that picturefque circumftance Ovid did not avail himfelf. Our modern Bard has been happicr.

So, on her fea-girt tower, fair Hero ftood At parting day, and mark'd the dafining flood, While bigh in air, the glimmering rocks above, Shone the bright lamp, the pilot-itar of love. With robe out-fpread, the waving flame behind, She kneels, and guards it from the rifing wind; Breathes to her Goddefs * all her vows, and guides Her bold Leander o'er the dufky tides ; Wrings his wet hair, his briny bofom warms, And clafps ber daring lover in her arms.

The charm of appropriation, as evinced in the third couplet of the above paffage, exifts only with the genuine Poet. Mere tuneful verfifiers know nothing of it, they reft in general defcription, and general defcription has been long fince exhaufted.

* Hero was a Prieftefs of Venus.

Geniras 
Genius knows this; he feizes the peculiar circumftance of the fituation; pours all his ftrength and light upon that, and leaves to the reader to conceive the whole by that diftinct and luminous part; but for which, the fcene would pafs unimpreflive over the mind of the examiner, and probably in no hour of recollection return to it again.

The Truffle, a well known fungus, which never appears above ground, now meets our attention as a fine lady, married to a Gnome, ftretched on beds of filvery af beftos, beneath a grand fubterranean palace; foothed by the muftc of the Eolian ftrings; which make love to tender Echoes in the circumjacent caves; while Cupids hover round and thake celeftial day from theiv bright lamps. It muft be confefied that the Emprefs of this proud palace has not the claim of birthright to her fplendor.

This perfonification is fucceeded by that of Caprifica, Wild Fig, as a Nymph who 2 B 3 numbers 
flumbers away her life on a downy couch. She is betrothed to a Sylph. Her awakening is compared to that of the infect in a nut, and to a young linnet on the inftant of it's firft flight from the neft. Caprifica ftrikes a talifman, and her airy hurband flies to her on the wings of a gnat. This flight is painted with lavin play of fancy; it's fwiftnefs is compared to that of the electric aura; it's impatient conftancy to that of the- polar needle. The Byffus of the northern Mores, which floats on their feas by day, and is found in their caverns, we fee ufhered to our notice by a fublime poetic picture of Fingall's Cave, of which Pennant's Tour to the Hebrides contains an engraving. The male and female of this vegetable become a Youth and Maid of thofe regions, purfuing their amorous voyage by night, in a boat with green fails, and lighted to their cave by the ftar of Venus.

Conferva 
Conferva Yolymorpha, found on the Englifh fhores, from the changeful appearance of the fubftance, is termed a Proteus Lover, and is reprefented after that fable. Beneath this fancy we fee him a Dolphin, a fpotted Pard, a Swan; and traits of the manners of each of thofe animals give poetic value to the transformations.

Adonis, many males many females in the fame flower. Here is the final metamorphofis of this great work of Imagination. The multifarious florets in each individual flower of that fpecies, are made to affume the human figure, and to become a band of libertine lovers, who plight their promifcuous hymeneals. To them is compared that licentious inftitution, the Areoi of Otaheite, as recorded in Cook's Voyages. slond now the Mufe of Botany difmiffes her minifters, and clofes her inchantments, thus: 
Here ceas'd the Goddefs. O'er the filent firings Applauding Zephýrs fwept their fluttering wings;

Enraptur'd Sylphs arofe in murmuring crowds, To air-wove canopies and pillowy clouds;

Each Gnome, reluetant fought his earthly cell, And each bright floret cloth'd her velvet bell. Then, on foft tiptoe, Night, approaching near, Hung o'er the tunelers lyre his fable ear;

Gemm'd witb bright ftars the ftill, etherial plain, And bade his niglitingales repeat the ftrain.

Thefe laft verfes drop the curtain, with ferene dignity, over a brilliant little world of Genius and it's creations. The paffage may not poffers the fpirit and fublimity which attach to a number of others in this divifion. Probably the Poet remembered the plainnefs with which Homer, Virgil, and Milton, clofed their Epics, and chofe to diffufe over his farewell lines an emulous fobriety. Perhaps the whole Canto, with all it's mafs of picturefque elegance, has more famenefs, lefs grandeur, lefs fublimity, than any of it's predeceffors in either part of this magnificent Poem. 
It feems to bear that pecies and degree of inferiority to the three former Cantos, as the Loves of the Plants, confidered as an whole, bears to the fublimer firft part, the Economy of Vegetation; where we find imperfonifed each various elementary property of Creation, as a race of miniftrant Beings, endowed with fcientific intelligence and benevolent powers. They tife before us, the Hatidmaids of Nature, ordained to watch over all het operations and productions, on earth and beneath it; in air and in ocean; as Natute herfelf appears in the fernblance of the Godders of Botany.

Perhaps it would have been better if her proper and general name, Nature, had been affigned to het in the, Economy of Vegetation, and the botanic title been referved exclufively for the Mufe in the Second Part, who records the transformations and the loves of the Plants and Flowers. In that cafe, 
cafe, to her alfo would have been refigned the floral car and it's gay defcent, and a sehicle of graver magnificence fupplied it's place to the "Mighty mother," immortal Nature, Nymph, or Goddefs of Botany, implies empire only over the vegetable part of creation; while, in the Economy of Vegetation, the prefides over the aftronomic, electric, aerial, and mineralogic properties. Into fo wide a field has the union of Philofophy with Poetry conducted this daring Bard. The light of his imagination will fhine with increafing luftre in the eyes of future generations, fo long as difcerning Tafte fhall be the Veftal to watch and fupport it's fires.

Nor let it once be thought that any error in Dr. Darwin's poetic fyftem; any occafional deviation from perfection in the plan, arrangement, or execution of this his complicated work, ought to prevent it's being confidered as one of the richeft ef- 
fufions of the poetic mind, that has fhed luftre over Europe in the eighteenth century.

- Human ability ncver did, and probably never will, produce an abfolutely perfect compofition. The author of this memoir has, from infancy, feduloufly ftudicd and compared the writings of the diftinguifhed Bards of her nation, together with the beft tranlations of thofe of Greece, Rome, and modern Italy. She has prefumed to defcant upon what appeared to her the graces and defects of the Botanic Garden; induced by a conviction that the unbiaffed mixture of candid objection with due praife, better ferves the intereft of every fcience than blind unqualified encomium upon it's pro. feffors. Hence, rifing Genius may be guarded againft the betraying influence of enthufiaftic homage; which, charmed by general cxcellence, melts down particular defest in it's thining mars. So doing, the inexperienced 
inexperienced and ardent fancy is full as liable to adopt the faults as to attain the merits of the author it emulates.

By unprejudiced inveftigation, that fickly, partial, and faftidious tafte which confines it's attention and it's praife to a few chofen and darling writers, may be induced to reflect, that if, after a juft balance of beauty and defect, the firft outweighs the latter in immenfe degree, then attention, love, and applaure is due to that work as an whole, in which fuch preponderance is found.

Pofterity, if not always, yet generally acts upon that fair principle in the meafure of fame it allots, when the mifts of prejudice, from caufes foreign to the intrinfic claims of an author, thall difperfe. Thofe compofitions which, with a confiderable degree of genius, are jet level to the comprehenfion of ordinary minds, immediately attain their full meafure of celebration; but it is feldom that poetry of the higher orders 
beders is cxempt from thofe mifts; it muft fruggle through them into full and univerfal day.

The flowly-accumulating fuffrages of thofe difcerning and generous readers who delight in fertile and daring Genius, will accumulate for the Botanic Garden, as they have for many other poems, whofe early appreciation was dubious; whofe celebration, during the life of their authors, was far from being uncontroverted. When . that time fhall come, the querulous and difdainful tones of peevirh prejudice will not venture to affail the ear of an admiring Nation, proud of it's diftinguifhed Sons. Then, however imperfection niay ftill be perceived in this as in all other works of bold imagination, it will be obferved without acrimony, and with grateful delight in it's plenteous atonement.

No eminent Poet has fo many pafiages which are every way exceptionable, as the 
mof eminent Poet that this, or perhaps any other nation has produced from the morning of Time, our great, our glorious Shakefpeare.
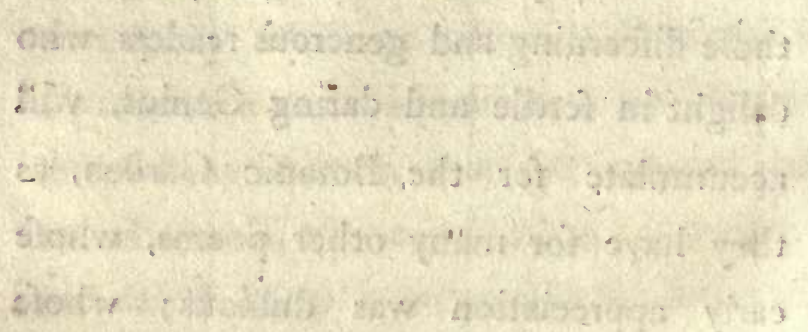


\section{CHAPTER VII.}

Before Dr. Darwin ftood forth a candidate for the Delphiclaurels, he was extremely alive to the beauties of poetic literature, as it rofe and expanded around him. No perfon could be more ready to difcern and to praife it's graces; but, from the commencement of the Botanic Garden, the jealous fpirit of authorifm darkened his candor. When, with avowed delight in the poetic powers of Cowper's Tark, the writer of thefe ftrictures, in converfation with Dr. Darwin and Sir Brooke Boothby, anked their opinion of that poem, each declared they could not read it through; each taxed it with egotifm, with profaicifm, with a rough and flovenly ftyle, and with 
utter want of regular defign. Perhaps thofe cenfures, unbalanced by juft praife, fhould not, however, be imputed folely to unworthy jealoufy in either of thofe gentlemen; certainly not to Sir Brooke, at any rate, who, with all his native brilliance of fancy, was never tenacious of the Mufes" favors. Both had always preferred rhyme to blank verfe, afferting that it better fuited the nature of our language. Dr. Darwin had ever maintained a preference of Akenfide's blank verfe to Milton's; declared that it was of higher polifh, of more claffic purity, and more dignified conftruction. This preference may fairly allow us to place his blindnefs to the charms of the Tafk to the fcore of tafte fomewhat enervated by too much refinement, rather than to forenefs under rival reputation. A fill more fcrupulous attachment to claffic elegance attaches to the opinions of Sir Brooke, refpecting Poetry. It was thence, doubtlefs, 
lefs, that he became difgurted by the planlefs wanderings of 'Cowper's Mufe, in her principal work, and by the occafional roughnefs and profaicifm of it's ftyle. Another prejudice in the minds of each was likely to have operated in producing this injuftice to Cowper. Previous to the Tank he had publifhed poems in rhyme, into which they had probably looked. In thofe poems, whatever ftrength of thought may be found, the poetic effentials certainly are not, inharmonious as is their verfification; barren as they are of landfcape and picture, metaphor and imagery.

The author of the Tank was more juft to Darwin than he had been to that fpirited, that interefting, that often fublime, though not faultlefs compofition. About the year I792, Mr. Cowper fent Dr. Darwin a lively and pleafing encomium in verfe upon the Botanic Garden. This agreeable eulogy juftly fays, no Poet who can refufe to $2 \mathrm{C}$ beftow. 
beftow a wreath on Darwin deferves to obtain one for himfelf. It was accompanied by another poetic tribute from $\mathrm{Mr}$. Hayley, of yet warmer praife and more brilliant grace.

Mr. Polwhele alfo addreffed a fine fonnet to Dr. Darwin on his Botanic Garden, who, by inferting it in his work, proved that he thought highly of it's merit, and that he confidered fuch praife as genuine fame. The neglect of Mr. Polwhele's poetic writings is a difgrace to the prefent period of Englifh literature.

Our botanic Poet had in general no tafte for Sonnets, and particularly diniked Milton's. The characteriftic beauties of the legitimate fonnet, it's nervous condenfation of idea, the graceful undulation of it's varied paufe, which blends with the fweetnefs of shyme the dignity of blank verfe, were all loft on Dr. Darwin, at leaft from the time in which he entertained the defign of becoming 
coming a profeffed poet. Abforbed in the refolve of bringing the couplet-meafure to a degree of fonorous perfection, which fhould tranfeend the numbers of Dryden and Pope, he fought to confine poetic excellence exclufively to that fyle.

" Defiring much the letter'd world might own

"The countlefs forms of beauty only one."

From the time at which Dr. Darwin left Lichfield to refide at Derby, on the irrefiftible injunction of Love, the author of thefe memoirs will not attempt to trace more than the outline of his deftiny, not poffeffing the means of giving it's interior parts with fufficient precifion.

The pen which on thefe leaves has purfued him through his afcending day to it's meridian, may yet remark that Dr. Darwin's reputation as a poet firft emanated from Derby, though his delphic infpirations commenced at Lichfield; that as a phyfician his renown ftill increafed as time 
rolled on, and his mortal life declined from it's noon. Patients reforted to him, more and more, from every part of the kingdom, and often from the Continent. All ranks, all orders of fociety, all religions leaned upon his power to ameliorate difeafe, and to prolong exiftence. The rigid and fternly pious, who had attempted to renounce his aid from a fuppofition that no bleffing would attend the prefcriptions of a fceptic, facrificed, after a time, their fuperftitious fcruples to their involuntary confcioufnefs of his mighty fkill.

Wealth muft have flowed in rapidly beneath employment of unprecedented extent, at leaft in any country practitioner; and from the large fums for which he fold the copy-right of his writings, poetic and philofophic. The fweet temper and benevolence of that long adored wife, for whofe fake he had changed his fphere of action; the numerous young family which rofe 
and bloomed around him, rendered the Lares of his hearth not lefs aufpicious to Darwin than he had found the gifts of Fortune and the voice of Renown. His fon Erafmus, by the former wife, had fettled at Derby nearly as foon as himfelf went thither, and in the profeffion of the law obtained confiderable practice, with fair reputation. The talents and virtues of his youngeft fon, by the firft marriage, were making every promife of that profperity which has fince been amply fulfilled.

The Zoonomia, of fo much elder birth than the Botanic Garden, fuffered her poetic younger fifter to precede her on their entrance into the world of letters, and did not herfelf appear till the year 1794 . Of the Zoonomia fufficient has been faid in the former part of this biography, confidering the writer's limited powers to speak of it's excellences and defects.

About thirteen or fourteen years after

$$
2 \text { C } 3 \text { Dr. }
$$


Dr. Darwin's fecond marriage, the Mirs Parkers, his relations, opened a female boarding-rchool at Ambourn in Derbyfhire. To the education of thofe ingenious and good young women he had paid fome general attention, and had feduloufly and warmly, by recommendation and by other means, exerted himfelf to ferve them. To promote the fuccefs of their undertaking he publifhed, on it's commencement, a fmall tract on Female Education. The precife time of it's appearance is not recollected. The compofition was by no means worthy of Dr. Darwin's exalted abilities. It's fubject cannot be fuppofed to have employed much of his confideration.

The fyftem of his whole life on that theme had been at war with all fort of reftraint on the time, the amufements, and the diet of children. Irony was the only corrective weapon he had ever ufed to his 
own. The docility of them all, and the talents and good qualities of his three eldeft fons, one, alas! cut off in the dawn of manhood and of fame, and the happy profpects of the other two, had confirmed his difdain of inceffant attention to young people. He always faid, "If you would "s not have your children arrogant, con" ceited, and hypocritical, do not let them "perceive that you are continually watch"ing and attending to them; nor can you " keep that perpetual watch without their " perceiving it. Infpire them with a dif" dain of meannefs, falfehood, and promife"6reaking; but do not try to effect this "purpofe by precept and declamation, but, " as occafion arifes, by expreffed contempt s6 of fuch as commit thofe faults, whether " it be themfelves or others. Teach them " benevolence and induftry by your own " example, for children are emulous to " acquire the habits of advanced life, and

$$
\text { 2. } 4 \text { "attach }
$$


"6 attach to them an idea of dignity and "importance."

Perhaps, if Dr. Darwin had to this incomplicate and fo eafily practicable fyftem, added the infpiration of religion by the fame means, viz. expreffed contempt for impiety, and daily example of gratefuldevotion, it would better anfwer the end of making wife and good men and women, than all the laboured Treatifes on Education which have, of late years, been poured from the prefs; Treatifes fo univerfally read, fo feldom, if ever, even in the flighteft degree, reduced to practice! In truth they muft be found impracticable, inconfiftent as they are with the eftablithed habits of fociety. Obedience to their directions muft devote every prefent generation, at leaft the maternal part of every prefent generation, to preparing the future. Every mother muft be wholly abforbed in word-watching, and look-watching, and all this by book. 
Yet was Dr. Darwin aware that thefe voluminous receipts to make human angels; or to make practical philofophers of every boy and girl in the higher and middle claffes of life, were too popular for him, without facrificing the defign of his Tract, to bring againft them his own concifer plan; which, if rational, does away the utility of them all. His little work could not ferve Mifs Parkers if it combated the educating metaphyficians and their unobeying admirers. Avoiding fuch combat, his Treatife would certainly call the attention of the neighbourhood to the feminary for which it was written. Some good rules for promoting the health of growing children will be found on it's pages, and they promifed unfeed attention from it's author to the difeafed in that fchool. On the whole, however, it is a meagre work, of Jittle general intereft, thofe rules excepted, and with an odd recommendation of certain 
novels of no eminence, to the perufal of young people. That was one of thore follies of the wife, which daily prefent themfelves to our furprifed attention.

In the year I79I a fplendid archerymeeting was held at Drakelow in Staffordthire, the feat of Sir Nigel Grefley. Mirs Sufan Sneyd * of Belmont, was diftinguifhed by her fkill and fuccefs in the conteft of that day. Honoured by Dr. Darwin's celebration, her name and her unerring arrow, are on permanent record. The verfes he wrote on that occafion appeared in the Derby paper anonymounly. There were people who pretended to be judges of verfe, and yet were in doubt concerning their author. Before Dr. Darwin acknowledged them, they were attributed to various verfifiers; and when the writer of this Tract, who faw the Darwinian famp on the lines at one glance, declared they muft be his,

* Now Mrs. Broughton. 
her affertion was repeatedly combated, as if the peculiar ftyle and manner of his mufe were not inftantly apparent.

\section{ON A TARGET AT DRAKELOW.}

With fylvan bow, on Drakelow's hadowy green, Arm'd like Diana, trod the Cyprian Queen. O'er her fair brow the beamy crefcent thone, And ftarry fpangles glitter'd round her zone; Love's golden thafts her fnow-white houlders prefs'd, And the fring'd ribbon crofs'd upon her breaft.

With carelefs eye the view'd the central ring, Stretch'd her white arms, and drew the filken ftring! Mute wonder gaz'd the brazen ftuds betwixt; Full in the bofs the flying arrow fix'd! Admiring circles greet the vietor-fair, And fhouts of triumph rend the breezy air; Trent, with loud echoes thrills the flowery grounds, And Burton's towers return applaugive faunds.

The graceful Huntrers eyes the gaudy grove, And bends again th' pnerring bow of Lave. Now guard your hearts, with playful malice cries, And wing'd with fmiles the fhining arrow flies; With random aim the dazzled crowd the wounds, The quiver'd heroes ftrow the velvet grounds; 
Beau after beau expiring, prints the plain, And Beauty triumphs o'er the archer train.

Now, with light bound, the mounts her wreathed car, Rolls her blue eyes, and waves her golden hair. Fond youths bow homage as the wheels proceed, Sigh as they gaze, and call the goddefs, SNEXD!

There are beautiful lines in this little compofition, but it is not faultlefs. The fourth and fifth couplet form the mort ftriking and elegant picture which poetry can exhibit of a graceful young woman emplayed in arrow-hooting. The epithet careless has the accuftomed felicity of this author, in giving character to his portraits; fince it implies that perfect confcioufnefs of $\mathrm{k}$ ill which precludes all ftrain and effort of attitude, fo prejudicial to grace ! In thefe verfes Mifs Sneyd is defcribed as fending the arrow from the yew, as Dryden makes Cleopatra caft from her eyes the darts of Love, on her voyage down the Cydnus; 
As if fecure of all Beholders' hearts,

Neglecting the might take them.

The metaphoric thooting which fucceeds to acclamations for the fair-one's victory, had perhaps better have been omitted. "Beau after beau," founds equivocally to the ear, in a fcene thronged with bows and arrows; befides, beau is in itfelf an effeminate and uncharacteriftic title for a number of young men in the uniform of Woodmen, and in manly fport with a weapon, dignified by it's' ancientry, and by which Britons of old not only flew the wild boar and the ftag, but repelled their foes when warriors cried aloud in the battle,

Draw, Archers, draw your arrows to the head!

There is alfo fomewhat too much fplendor in the departure of the Conquerefs, for why Thould her vehicle be wreathed? A filver arrow, and not a garland, is the coftume of archery reward. However, the final couplet 
is elegant; the eulogy clofing with the

- name of it's fubject has an happy effect.

Soon after the death of that variounlycharming Poet, Mafon, Dr. Darwin wrote, an Epitaph which he defigned fhould be engraven on his monument. We may be certain, however, that it has not there been infribed. As an infcription for an urn in a garden or grove, alter a few of the lines for that purpofe, and the verfes are excellent, though, from being utterly without religious hope or truft, they are improper for a tomb-ftone.

FOR THE MONUMENT OF THE REV. W. MASON, BY DR. DARWIN.

Thefe aweful manfions of the honor d Dead Oft fhall the Mufe of Melancholy tread;

The wreck of Virtue and of Genius mourn,

And point, with pallid hand, to Mafon's urn. Oft thall the gather from his garden bowers*

Fistitious foliage and ideal flowers;

- Alluding to the Poem, Englim Garden. 
aneave the bright wreath, to worth departed juft,

And hang unfading chaplets on his buft; While pale Elfrida, bending a'er his bier, Breathes the foft figh and theds the graceful tear;

I And ftern Caractactis, with brow deprefs'd, Clafps the cold marble to his mailed breart. In lucid troops thall choral Virgins throng, With voice alternate chaunt their Poet's fong, And, $\mathrm{O}$ ! in golden claracters record

1. Each firm, immutable, immortal word!

Thofe laft two lines from the frnal chorus of Elfrida, admirably clofe this tribute to the memory of him who ftands fecond to Gray as a lyric Poet; whore Englifh Garden is one of the happiert efforts of didactic verfe: containing the pureft elements of horticul tural tafte; dignified by fentiments of freedom and virtue; rendered interefting by epifode, and given in thofe energetic and undulating meafures which render blank verfe excellent; whore unowned fatires, yet certainly his, the Heroic Epiftle to Sit William Chambers, and it's Poftfcript, are 
at once original in their fyle, harmonious in their numbers, and pointed in their ridicule; whofe Tragedies are the only pathetic Tragedies which have been written in our language upon the fevere Greek model. The Samfon Agoniftes bears marks of a ftronger, but alfo of an heavier hand, and is unqueftionably lefs touching than the fweet Elfrida; and the fublime Caractacus.

Since thefe pages were in the prefs, an Epitaph on General Wolfe firft met their author's eye in a collection of manufcript poetry; and it bears Dr. Darwin's fignature. Perfectly in his manner, the cannot doubt it's authenticity; elfe the names of deceafed people of eminence are fo often affixed to compofitions they never framed, that we ought to look jealounly at all which do not carry to the mind of the seader internal evidence of their imputed origin. But for fuch evidence the enfuing lines had found no place on thefe pages. 
ON THE DEATH OF GENERAL WOLFE.

Thy trembling hills, Quebec, when Victory trod, Shook her high plume, and wav'd her banner broad; Saw Wolfe advance; heard the dire din of War, And Gallia's genius thrieking from afar, With fatal hafte th' aftonilh'd Goddefs flew, To weave th' immortal chaplet for his brow. Cyprefs the gather'd with the facrel bays, And weav'd the afp of Death among the fprays. They fly ! they fly! th' expiring Hero cried, Hung his wreath'd head; thank'd the kind Gods, and died.

Will the reader again extend indulgence to the fpirit of authorifm, tenacious beneath a fenfe of recent injury? As in the courfe of this little work it's writer has claimed her own verfes from the fplendid poem the analyfed, fo will he now permit her to difclaim other verfes, that, by fingular effrontery (her exiftence confidered) have been printed fince, with her name affixed. In the Spring 1803 , the fent thefe memoirs to Mr. Johnfon for publication; the now, January 1804 , but firft difcovered 
covered an illegitimate Sonnet in one of the Gentleman's Magazines for Auguft or September laft, with her fignature at full length. It is addreffed to Mr. Dimond, of whofe poetic exiftence the had never heard, and it praifes a poem of his which the has never feen. One line of the forged fonnet begins, "Bright Dimond," thus making a miferable pun from an unfortunate name; and the writer's ear was defective enough to induce his alliterating with the harh th thus,

Young joys awake in many a t/2rilling throng;

which laft words form completely the Gander's hifs.

She finds alfo that thefe alternately-rhyming ftanzas, which call themfelves fonnet, are interpolated, and given as her's, in the 6th Vol. of Public Characters, recently. publined, fee page 554 of that Vol. They clofe anecdotes of her, that have been chiefly collected from previous tracts in the monthly publications. All are 
of much too partial defcription; and ftrangely indeed is the talent of finging agreeably attributed to her, who, confcious of total want of voice, never attempted to fing in her whole life. Amid thefe lateft anecdotes a ftanza is quoted from her "Ode to General Elliot on his return from "Gibraltar," and the quotation has two grofs mifprints, "induftrious foldier" for illuftrious foldier, and "honour to the lap of "peace," inftead of, honour on the lap of peace.

When this fonnet-forgery was contrived, it's writer forgot that the, whofe name was affixed to it, had, in her Preface to the Centenary of legitimate Sonnets, which the publifhed in 1798 , denied to three alternately rhyming ftanzas, clofing with a couplet, all right to the name of that peculiar and ftrict order of verfe. It was therefore moft unlikely that the fhould herfelf affume it for fourteen lines, written on the feeble model which the had reprobated.

$$
\text { 2. } 2 \text { But }
$$


But it is time to refume a more interefting fubject.

The clofe of the year 1799 brought a fevere trial to the ftoical fortitude of Dr. Darwin. From the period of his fecond marriage all had been funthine in his fortune, his fame, and domeftic connexions; but then a ftorm defcended upon his peace; unforefeen, fudden, dreadful! His eldeft fon, Mr. Darwin, fo profperoufly fituated, without one adequate caufe for even tranfient afliction, became the victim of fecret and utter defpair. It had often been obferved that any more than ordinary recurrence of profeffional bufinefs perplexed and oppreffed him. A demand was made that he fhould arrange and fettle fome complicated accounts, which a difpofition to procraftinate had too long delayed. A difpofition which is always, in a greater or lefs degree, punifhed by it's confequences. Though a remote, it is the moft frequent 
caufe of fuicide, accumulating debts till their entanglement becomes inextricable, their weight too heavy to be borne. But in this cafe it had produced only an accumulation of bufinefs. From the neceffity of entering upon it Mr. Darwin had feemed to fhrink with fo much dejection of fpirit as to induce his partner to intreat that he would leave the infpection folely to his management. He declined the propofal, faying, in a faint voice, that it was impoffible.

- This was on a December erening, cold and ftormy. The tiver Derwent, which ran at the bottom of his garden, was partially frozen. About feven o'clock he fent his partner out of the way on bufinefs, real or pretended. Mr. Darwin was on the couch complaining of the head-ach. Soon after eight his partner seturning found the parlour vacant. He wrent to Mr. D.'s upftair apartment: vacant alfo: inquired

$$
203
$$


of the fervants; they had not feen their mafter fince this gentleman went out, an hour before. He waited a few minutes expecting his friend's return from the garden. Not appearing, a degree of apprehenfion feized his mind, He ran thither, and in

- the walk which leads to the river, he found Mr. Darwin's hat and neckcloth. Alarm was immediately given, and boats were fent out. Dr. Darwin had been fummoned. He ftaid a long time on the brink of the water, apparently calm and collected, but doubtlefs fuffering the moft torturing anxiety. The body could not be found till the next day. When the Doctor received information that it was fuund, he exclaimed in a low voice, "Poor infane coward!" and it is faid never afterwards mentioned the fubject.

Mr. Darwin died in very good circumftances, leaving an untainted reputation for probity and benevolence; beloved, refpected, 
fpected, and mourned by all who knew him. He never married; had purchafed a pretty eftate near Derby, which, with all his other effects, he left to his father. The accounts, whofe apprehended embarraffment had proved fatal to him, were fettled after his death to the fatisfaction of all parties.

Though this unfortunate victim of caufelefs defpondency had a gentle, ingenuous, and affectionate heart, he attained middle life without any known or fufpected attachment of the impaffioned kind. There feemed a want of energy in his character, and too extreme a delicacy of feeling on the occurrence of every thing which was in the Mighteft degree repulfive. He had never loved bufinefs, and his attention to it appeared a force upon his inclinations. While his profeffion was undetermined, he expreffed a winh to go into the Church rather than the Law. That preference was repulfed 
by paternal farcafms upon it's indolence and imputed effeminacy. Fram infancy to his laft day, Mr. Darwin had fhrunk, with pained fenfibility, from his father's irony. Probably from the lefs active, lefs fcientific difpofition of Erafmus, in comparifon with that of his brothers, Charles and Robert, Dr. Darwin had always appeared colder towards him than to his other children. Doubtlefs it was that inferior degree of attachment which made the leffon of ftoicifm fomewhat more practicable on this trying, this dire accafion. It excited, however, univerfal furprife to fee him walking along the ftreets of Derby the day after the funeral of his fon, with a ferene countenance and his ufual cheerfulnefs of addrefs. This felf-command enabled him to take immediate poffeffion of the premifes bequeathed to him; to lay plans for their improvement; to take pleafure in defcrib- 
fing thiofe plans to his acquaintance, and to determine to make it his future refidence; and all this without feeming to recollect to how fad an event he owed their porfeffion!

The folly of fuffering our imagination to dwell an paft and irretrievable misfortunes, and of indulging fruitlefs grief, he often pointed out, and always cenfured. He relied much on felf-difcipline in that refpect, and difdained, from deference to what he termed the prejudices of mankind, to difplay the outward femblance of unavailing forrow, fince he thought it wifdom to combat it's reality. On occafions and fubjects which he confidered trivial, he profefied to indulge human prejudice; but whenever, by mock affent, he extended that indulgence, a flight fatiric laugh and a gay difdain lurking in his eye, counteracted the affumed poincidence. On circumftances which 
touched him nearly, he acted fteadily upon his own principles.

And there were fubjects out of himfelf on which he was always ferioufly and earneftly ingenuous. Politics was one. He hated war, and thought the motives few indeed, which could vindicate it's homicide, efpecially in this commercial and fea-defended country. That of forcing America into internal, unreprefented taxation, and of interfering, through jealoufy of her principles, with the internal government of France, he utterly difapproved. The event of both thofe contefts accomplinhed his prophẹcies, and juftified his difapprobation.

Early in the year, 1800, Dr. Darwin publifhed another large quarto volume, intitled, Phytologia, or the Philofophy of Agriculture and Gardening. The writer of thefe pages does not prefume to fpeak her opinion of this production as an whole; the 
the fubject did not induce her to read it regularly. Incompetent therefore to declared opinion as her perufal may have been, it has yet convinced her that in parts, at leaft, it is highly ingenious. Dr. Darwin's conviction that vegetables are remote links in the chain of fentient exiftence, often hinted in the notes to the Botanic Garden, is here avowed as a regular fyftem. The Phytologia infifts that plants have vital organization, fenfation, and even volition; and a number of inftances are adduced, which feem firmly to fupport the theory. Certainly thofe appear to fleep which clofe their petals at fun-fet, and unfold them in the rifing day. Dr. Darwin tells us that plants poffers low heat and cold blood, like winter-fleeping animals, and like them continue the defcending fcale of exiftence.

From this theory of vegetable fenfation fome good may proceed, and no evil can flow: 
flow. If the affluent improver of his paternal or purchafed domain, thall be impreffed with it's belief, fuch impreffion muft augment his pleafure in attending to the fuftenance, the growth, and comfort of his trees, his grain, his (hrubs, and his flowers. He will fay to himfelf, "It is I - who enable this little world of vegetation, " by my care, attention, and kindnefs, to "fmile upon the fun, and bafk delighted "s in it's rays." The labourer in the field and garden, affured that the grain and the plants he is cultivating will not only nurture his fellow creatures, but are themfelves capable of receiving comfort or difcomfort while yet they grow on the earth, will thence feel an additional motive to become worthy of his hire. Every honeft heart is gratified by the idea of contributing to the common ftock of happinefs. It is an idea which produces folf-refpect in the mind, which, 
which, when founded in benevolence, and not in haughtinefs, is the faireft and mort productive foil in which the virtues can grow, whether thofe virtues be lowly and plain in ignorance and poverty, or heightened and refined by knowledge and affluence.

Of this theory, however, Dr. Darwin is neither the fource, nor the firft who drew the fcattered hints of former philofophers concerning it, into a regular fyftem. The ingenious and excellent Dr. Percival, of Manchefter, preceded him in maintaining that fyftem from the prefs. Congeniality on it's fubject between a mild, a temperate, and religious fage, and a bold philofopher of the modern fehool, who poffeffed the eye of a lynx for nature's arcana, leave us little reafon to doubt that it is veritable. Why fhould we fuppofe the chain of exiftence broken at the laft, inert clafs of animals, 
animals, fince it's continuity is perfectly confonant to the order of creation?

The chain that leads from infinite to man,

From man to nothing.

\section{Night ThOUghts.}

The nourifhment of plants is next confidered with a view to their health and increafe; and ingenious experiments are ftated. The decompofition of water is afferted to be one of the moit important difcoveries of modern fcience. Thence was demonftrated the immenfe proportion of oxygene or vital air, with which water is impregnated, in comparifon with air which is lefs pure. A plentiful fupply of water abrolutely neceffary to fertilize foil. The wifdom afferted, and the means pointed out, of giving artificial and falutary moifture to arid fituations. On the contrary, where the ground is naturally too wet and fwampy, the neceffity of fubterranean and fuperficial drains is enforced. 
Sudden and violent fhowers extremely detrimental, from their wanhing down the diffufable and foluble parts of the foil into muddy rivers. It is obferved, that every fuch fhower conveys through thofe channels into the fea, many thoufand poundsworth of fertilizing matter, thus confiderably diminining the food of terreftrial animals, however it may add to the furtenance of the aqueous tribes. Great attention is neceffary to counteract the mifchief of thefe impetuous and impelling rains, equally noxious to the dry foil and fituation, as to thofe which are irriguous.

To fuch end we are informed that all hills fhould be ploughed horizontally, and not in afcending and defcending furrows; alfo, that floping fields of pafture-land might be laid in tranfverfe ridges and depreffions. Thus the water of thefe partial inundations would remain fome hours in the horizontal furrows of the ploughed hills, and in the 
the tranfverfe hollows of inclined plains, that are grafs-land. Thefe little detaining refervoirs muft be a great advantage in parched fituations, while in thofe which are wet and fpongy, they might be opened into each other by the fpade fo as to prevent that lofs of foil which muft refult from the downward rufh and fpeedy paffing away of the temporary deluge.

The grcat wafte in towns and cities, of fubftances capable of being converted into manure, is obferved and deplored; and in that refpect the better police of China held up to imitation. The author alleges, that finilar practice in Europe would at once promote the purity and confequent health of towns, and contribute to the econony and fertility of their furrounding countrics. He explains the means of accomplifhing purpofes fo defirable.

Here let the biographic pen arreft it's: courfe, 
courfe, nor attempt to follow this penetrating and excurfive mind through the wide and complicated mazes of agricultural differtation. Returning back to the verge of this vaft field of treafured obfervation and fcientific literature, the memorialift may be allowed to obferve what never-flumbering attention to the operations of nature and the prefent ftate of cultivation; wi hat unwearied refearch into the records of other philofophers, this book evinces! A man of fuch immenfe proferfional engagements as Dr. Darwin, comporing and publifhing this work only, had built his lettered reputation upon no narrow or unftable bafis. But when we confider it as a brother-production to the Zoonomia, two large quartos, as bulky, as fmall a type, and as crowded writing as the Phytologia ; when we confider alfo his fplendid poetic work, with it's hoft of philofophic notes; there is furely no partiality to him, no want of 
candor to others, in maintaining that it can only be from native littlenefs or acquired warp of mind, where the greatnefs and energy of Dr. Darwin's genius and knowledge are denied. Yet let it be remembered, that it is poetic eminence, not pre-eminence, which has here been demanded for his mufe. Superlative epithets have found no place in his eulogium on thefe pages; for their author remembers and reveres the exalted claims of his poctic predeceffors and contemporaries of the eighteenth century. Incomparable, unrivalled, matchlefs, are terms of applaufe which can only be, with truth, applied to three men of genius in times paft or prefent; to Shakefpcar as a dramatic poet; to Newton as a philofopher; to Handel as a mufician; not to Homer, not to Milton, fince they ftand abreaft with each other, and divide the epic palm. Perhaps, without trefpafs on literacy truth, Gray might alfo 
alfo be termed peerlefs, as a lyric poet, fince he equals Pindar in the dignity of his language, in the fublimity of his imagery, and in the interwoven morality, alternately aweful and tender; and fince he chofe fubjects fo much more exalted than the Pindaric themes, for thofe two great Odes which place him firft at the goal of the Lyric Mufe. Their meafures are magnificent and harmonious to the utmoft power of the Englifh tongue. Pindar could not carry that excellence higher in the Greek. language; therefore if any fuperiority remains to the ancient claffic, refpecting his metre, it muft refult from the more fonorous tones of the Greek, not from tranfcendence of genius in it's great lyrift, compared with the Brition poet. Whatever importance the fafhion of that period might attach to Pindar's themes, however mythologic and hiftoric allufion might give them auxiliar elevation, yet the foot-races

$$
2 \text { E } 2
$$


of children, though the fons of princes, and the chariot-races of youthful heroes, poffefs no eternity of attraction compared to the fubject of Gray's Progrefs of Poefy, and of his Bard. For the firt, the phyffcal and moral powers of the mufes; their univerfal influence, in different degrees, in every clime; the three great feats of their empire, Greece, Italy, and England, Dramatic, Epic, and Lyric Poetry, fupported in Britain by Shakefpear, Milton, and Dryden.

For the fecond, and ftill greater Ode, the fanguinary crime againft the Mufes committed by an otherwife illuftrious monarch, the fuppofed confequences of that crime, a train of misfortunes to the remaining line of the Plantagenets; it's reçal fons,

Another and another gold-bound brow,

paffing before us in the awful obfcurity, the "darknefs vifible" of poetic prophecy; the 10 acceffion 
acceffion of another royal houfe, in which the rival rofes were entwined; the brilliant reign of it's virgin queen, who was to carry the profperity and the renown of a great nation to it's utmoft line; the day of poefy, funk in eclipfe from the period of the maffacre, rifing again with redoubled fplendor in that epoch; the exultation of the Cambrian. Bard who thus forefees the reftored glory of his art in the genius of him who fung the fairy region, and by that of the mighty mafter of the fock and bufkin; the continuance of that glory through future times by the Song of Eden, and the ftrains of fucceffrve warblers; the exulta. tion clofing by the plunge of the injured Bard amid Conway's deep and tumultuous flood! Can pedeftrian fpeed, and the dexterity of the whip and rein, by any effort of talent, be raifed to the intrinfic grandeur of themes like thefe? Ah! when will our fchools and univerfities; exchange

$$
2 \text { E } 3 \text { claffical }
$$


claffical partiality for patriotifm, and become juft to the exalted merits of the Englifh Poets? To that fincere and ardent patriotifm the author of thefe memoirs hopes will be remitted her tributary digreffion to the fame of Gray.

Sunday, the eighteenth of April, I802, deprived Derby and it's vicinity, and the encircling counties, of Dr. Darwin; the lettered world of his genius. During a few preceding years he had been fubject to fudden and alarming diforders of the cheft, in which he always applied the lancet inftantly and freely; he had repeatedly rifen in the night and bled himfelf. It was faid that he fufpected angina pelioris to be the caure of thofe his fudden paroxyfms, and that it would produce fudden death. The converfation which he held with Mrs. Darwin and her friend, the night before he died, gave colour to the report. In the freceding year he had a very dangerous jllnefs. 
illnefs. It originated from a fevere cold caught by obeying the fummons of a patient in Derby, after he had himfelf taken ftrong medicine. His fkill, his courage, his exertion, ftruggled vehemently with his difeafe. Repeated and daring ufe of the lancet at length fubdued it, but, in all likelihood, irreparably weakened the fyftem. He never looked fo well after as before his feizure; increafed debility of ftep, and a certain wannefs of countenance, awakened thofe fears for him which great numbers felt who calculated upon his affiftance when hours of pain and danger might come. It was faid, that during his illners he reproved the fenfibility and tears of Mrs. Darwin ${ }_{2}$ and bid her remember that The was the wife of a philofopher. ! ! !! ! !

The public papers and magazines recorded, with tolerable accuracy, the nature of his final feizure; the converfation he held in the garden of his new refidence, the

$$
2 \text { E } 4 \text { Priory, }
$$


Priôry, with Mrs. Darwin and her female friend; the idea which he communicated to them, that he was not likely to live to fee the effect of thofe improvements he had plantied; Mrs. Darwin affectionately combating that idea by obferving, that he looked remarkably well that evening; his reply that he had generally found himfelf in his beft health a few days preceding his attacks; the fpirits and ftrength with which he arofe the next morning at fix to write letters; the large draught of cold butter-milk, which, according to his ufual cuftom, he had fwallowed. All thefe circumfances early met the public eye; and, in the imperfect Aketches of his life which accompanied them, a ftrange habit was imputed to Dr.Darwin, which prefents fuch an exterior of idiot-feeming indelicacy that the author of this tract is tempted to exprefs her intire dipbelief of it's truth: viz. that his tongue was generally hanging out 
gut of his mouth as he walked along. She has often, of late years, met him in the ftreets of Lichfield, alone and mufing, and never witneffed a cuftom fo indecent. From the early lofs of his teeth he looked much older than he was. That lofs expofes the tongue to view while fpeaking; and Dr. Darwin's mouth certainly thus difclofed the ravages of time, but by no means in any offenfive degree.

It was the general opinion that a glafs of brandy might have faved him for that time. It's effects would have been more powerful from his utter difufe of fpirits; but füch was the abhorrence in which he held them, that it is probable no intreatios could have induced him to have fwallowed a dram, though furely, on any fudden chill of the blood, it's effect, fo injurious on habitual application, might have proved reftoring.

.. On that laft morning; he had written 
one page of a very fprightly letter to $\mathrm{Mr}$. Edgeworth, defcribing the Priory, and his purpofed alterations there, when the fatal fignal was given. He rang the bell, and ordered his fervant to fend Mrs. Darwin to him. She came immediately, with his daughter, Mifs Emma Darwin. They faw him fhivering and pale. He defired them to fend directly to Derby for his furgeon, Mr. Hadley. They did fo; but all was over before he could arrive.

It was reported at Lichfield, that, perceiving himfelf growing rapidly worfe, he , faid to Mrs. Darwin, "My dear, you muft " bleed me inftantly." "Alas, I dare " not, left_" "Emma, will you? There "6 is no time to be loft." " "Yes, my dear "father, if you will direct me." At that moment he funk into his chair, and expired!

The body was opened, but it was faid the furgeons found no traces of peculiar difeafe; 
difeafe; that the ftate of the vifcera indicated a much more protracted exiftence; yet thus, in one hour, was extinguirhed that vital light which the preceding hour had thone in flattering brightnefs, promiring duration; fuch is often the " cunning "flattery of nature;" that light, which, through half a century, had diffured it's radiance and it's warmth fo widely; that light, in which Penury had been cheered, in which Science had expanded; to whofe orb Poetry had brought all her images; before whofe influence Difeafe had continually retreated, and Death fo often turned afide his levelled dart!

Awful is the leffon of fuch an extinction; trebly awful in it's fuddennefs. Let no one fay that it is not more awful than the fimilar deftiny of ordinary human beings; for the impreffion made by unexpected, immediate, and everlafting abfence, will be diffufive, will be ftrong, in propor- 
tion to the abilities and ufefulners of thofe who vanifh at once from fociety. We feel the folemn leffon fink deep into our hearts when minds, fo largely endowed and adorned, evince, in their fate, the truths uttered by, that fublime Poet*, who made the threats and the promifes of the Gorpel the theme of his midnight ftrains; and thus they admonifh,

By nature's law, what muft be, may be now';

There's no prerogative in human hours.

In human hearts what bolder thought can rife

Than man's prefumption on to-morrow's dawn?

Where is to-marrow ? - In another worla!

For numbers this is certain, the reverfe

Is fure to none; and yet; on this perhaps,

This peradventure, infamous for lies,

As on a rock of adamant, we build;

Though every dial warns us as we pafs,

Portentous as the written wall, that turn'd,

O'er midnigbt bowls, the proud Affyrian pale!

Another, and the laft poetic work of Dr. Darwin, is now in the prefs. The * Dr. Young. 
Temple of Nature. His memorialift, on thefe pages, has not feen a line of the compofition. The curiofity of the ingenious muft be ardently excited to view the fetting emanation of this brilliant day-ftar; they muft hope that neither age, difeafe, nor the dread calamity he had endured, in December 1799, thed mift or cloud upon it's rays.

Dr. Darwin died in his fixty-ninth year. - This Tract is prefented to the Public beneath it's author's idea, that it may probably difpleafe two clafies of readers, hould it attract their notice; the dazzled idolaters of the late Dr. Darwin, who will not allow that there were any fpots in his fun; and that much larger clafs, who, from party prejudice, religious zeal, or literary envy, or a combination of all thofe motives, are unjuft to his high claims; at leaft as a Philofopher and Poet. There is another clafs of readers, who, if thefe faithful records thall be honored by their perufal, 
will feel gratified to fee one diftinguifhed character of thefe times, neither varnimed by partiality, nor darkened by prejudice. They muft be confcious that human beings, whatever may have been their talents, whatever their good qualities, are feldom found perfect, except on the pages of their eulogifts; confcious alfo, that, while the intellectual powers of the wife and the renowned, excite admiration, their errors may not lefs ufefully be contemplated as warnings, than their virtues as examples.

\section{LICHFIELD,}

April 13, $18 Q 3$.

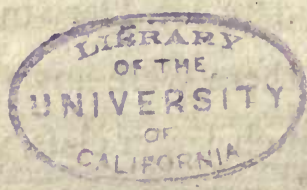

THE END. 


\section{$\therefore$ E R A T A.}

Page 19, 1. 5. after "reafoner," infert "while."

20, 1. 1. read "refiftance, only juft," 1. 7. read " their refiftance."

21, 1. 7, for "That," read "The refult."

31, 1. 5, for "Thefe" read " There."

$93,1.18$, for " proficience" read " proficiency."

$109,1.10$. for "that they would," read " to."

$215,1.17$, for " love" read " lover."

233, 1. 2, from bottom, for " his" read " it"s." ,

243 note, read, "what an."

270 TO LEwISDON HILL add a Note. This poem was printed at the Clarendon Prefs Oxford, 1788, and fold by Prince and Conke of that city, and Cadell, Rivington, and Faulder, London. $325,1.1$. place a comma after " treads." 


\section{WRITTEN BY DR DARWIN,}

AND SOLD BY J.JOHNSON, IN ST. PAUL'S CHURCH-YARD.

1. The BOTANIC GARDEN, with Philofophical Notes, in Two Parts.

Part 1. The Economy of Vegetation.

2. The Loves of the Plants.

In Two Volumes 8vo. Embellifhed with Plates, $21 \mathrm{s.} \mathrm{Boards.}$

2. The TEMPLE OF NATURE, or the Origin of Society, A Poem in Four Cantos, with Philofophical Notes and Plates. Quarto, 11.5s. or on large paper, 11. $16 \mathrm{~s}$. in Boards

3. ZOONOMIA, or the Laws of Organic Life. In Four Volumes $8 \mathrm{ro}$. Illuftrated with Plates, $36 \mathrm{~s}$. Boards on Fine Paper, 48 s.

4. PHYTOLOGIA, or the Philofophy of Agriculture and Gardening, with the Theory of draining Moraffes, and an improved Conftruction of the Drill Plough. Quarto, 11. $11 \mathrm{~s} .6 \mathrm{~d}$. in Boards.

5. Plan for the Conduct of Female Education in Boarding Schools. Quarto, $5 \mathrm{~s}$. 


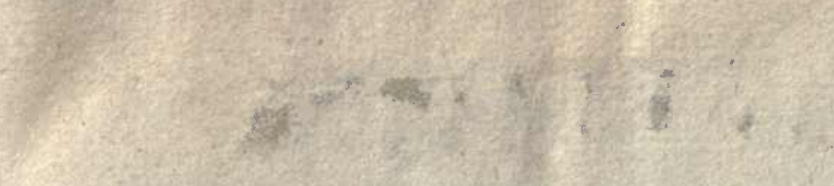

I.

W.

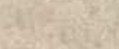

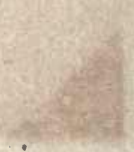

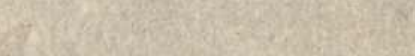

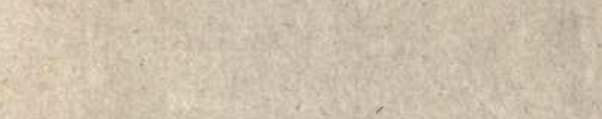

$2 x^{2}$ 
THIS BOOK IS DUE ON THE LAST DATE STAMPED BELOW

AN INITIAL FINE OF 25 CENTS WILL BE ASSESSED FOR FAILURE TO RETURN THIS BOOK ON THE DATE DUE. THE PENALTY WILL INCREASE TO 50 CENTS ON THE FOURTH DAY AND TO \$1.00 ON THE SEVENTH DAY OVERDUE.

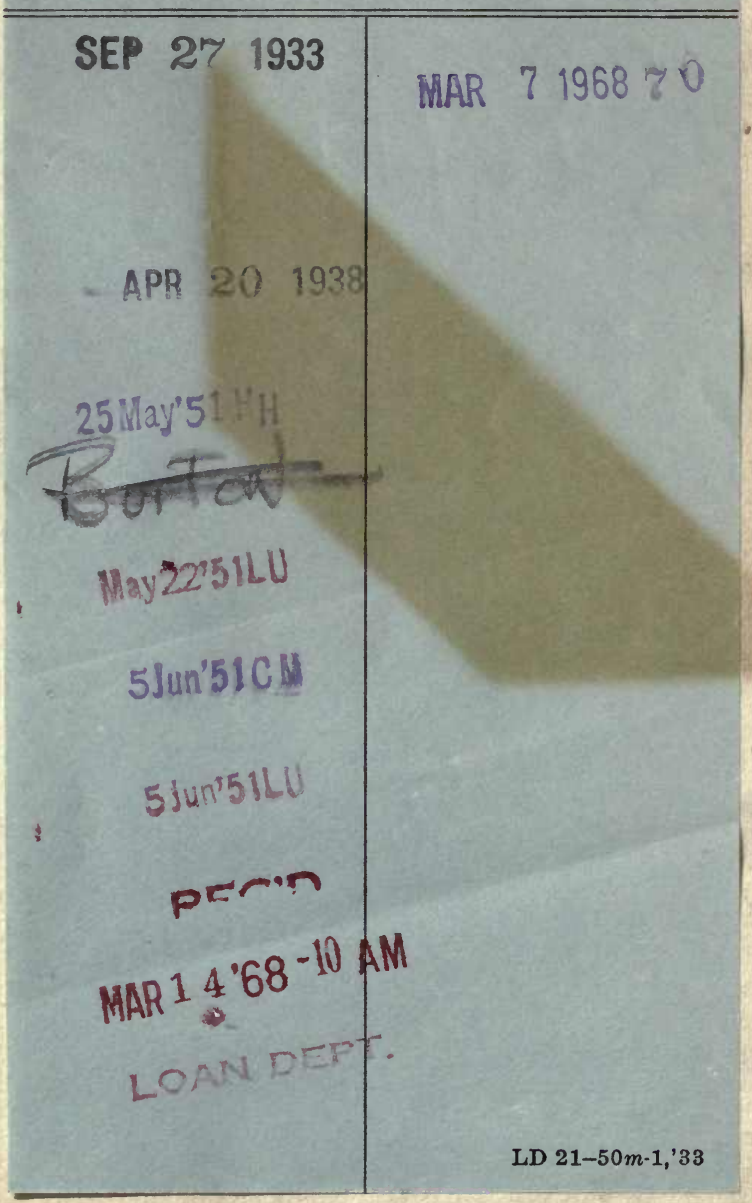


